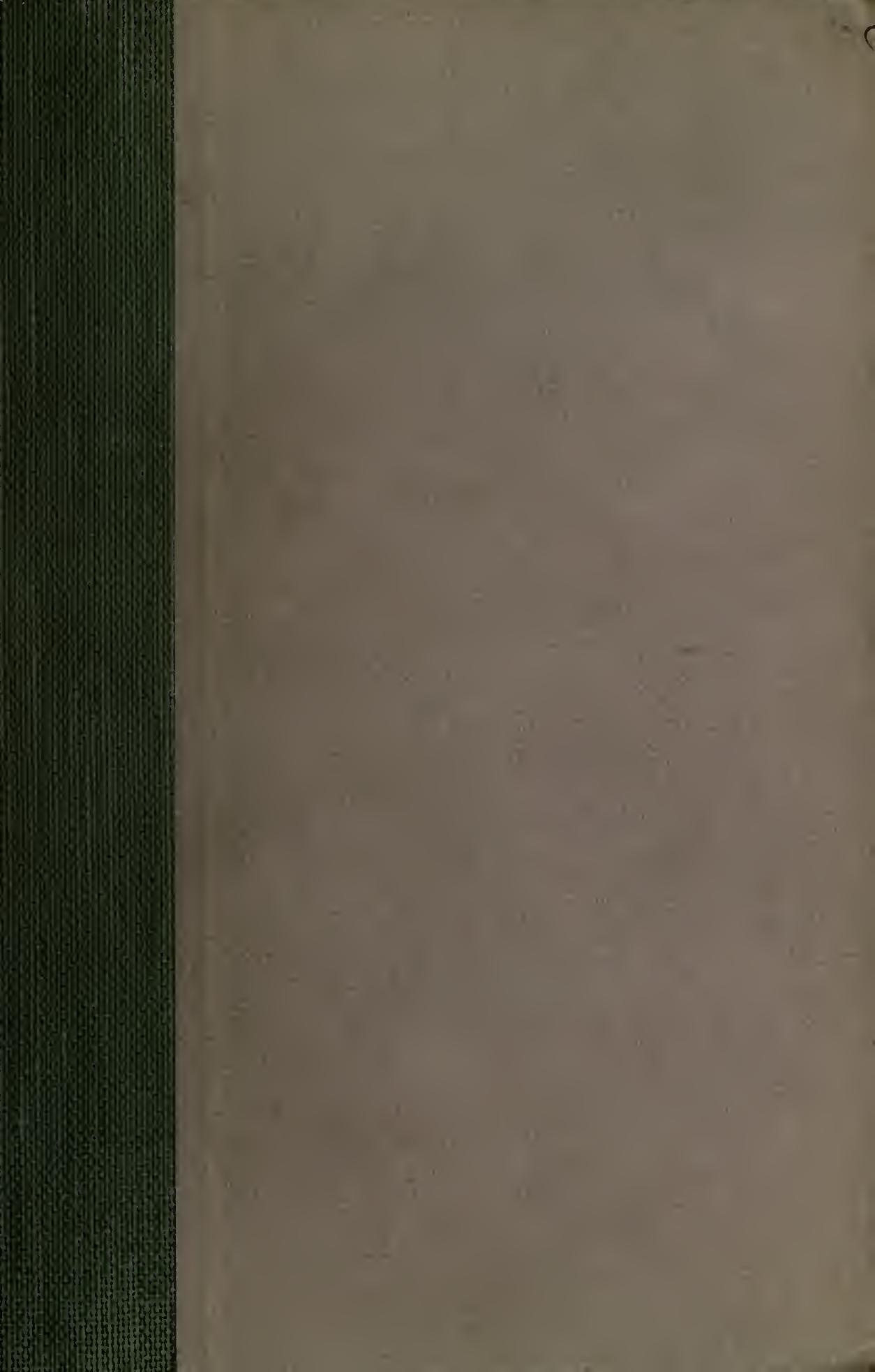




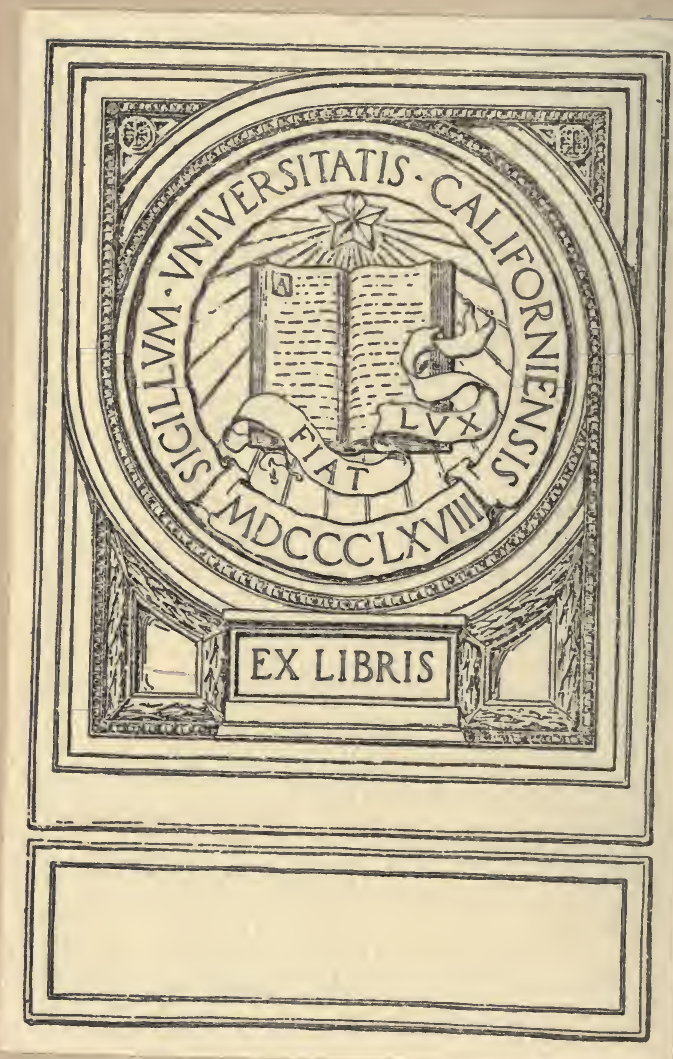




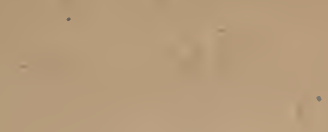

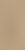

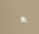
-

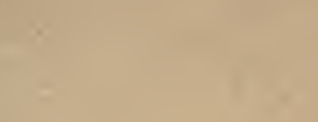

$\sqrt{2}+x^{2}$
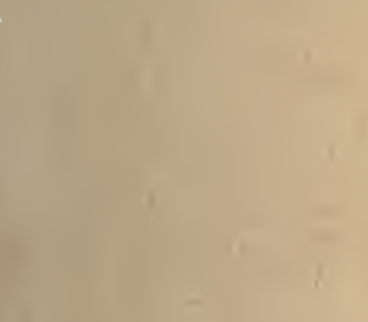

$+2$

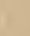


Digitized by the Internet Archive in 2007 with funding from - Microsoft Corporation 
MOSTLY ABOUT TROUT 
BY THE SAME AUTHOR

MEMORIES OF A MARINE

WAR LESSONS, NEW AND OLD 


\title{
MOSTLY ABOUT TROUT
}

\author{
BY \\ SIR GEORGE ASTON \\ (GEORGE SOUTHCOTE)
}

\section{BOSTON \& NEW YORK HOUGHTON MIFFLIN COMPANY




$$
\begin{aligned}
& 5+687= \\
& A^{8}
\end{aligned}
$$


"HERSELF" 

The cities we do not need at all. The cities make people think like men who have fallen sick and are lying in bed with fever. Only on farms or deep in the forest, or out on the river while you fish, can you think a thing out clearly. For there your life goes quietly, and you learn only what is worth while.

\section{Ernest Poole,}

Russian Impressions: "The Village." 



\section{PREFACE}

THE fishing-stories in this book are all true. Brother-fishermen will realize that I have given only the cream of fishing experiences, which extend over half a century; successes like these that I have described would soon pall if they were the rule rather than the exception.

GEORGE SOUTHCOTE.

SAlusbury, 1921.

My sincere thanks are due to the Editors of the Cornhill Magazine, the Nineteenth Century and After, Country Life, the Pall Mall Gazette, John o' London's Weekly, The Englishman and the Liverpool Courier for their concurrence in the inclusion of the portions of this book which have appeared in their pages. 



\section{CONTENTS}

Preface

\section{PART I \\ INTRODUCTORY}

I. Philosophies of a Fisherman a $\quad 15$

II. My First Trout $\quad$. $\quad$ - $\quad$ - 20

\section{PART II}

\section{A FLY-FISHER'S YEAR}

I. The TURN OF the Yhar : $\quad$ e $\quad$. $\quad$ - 29

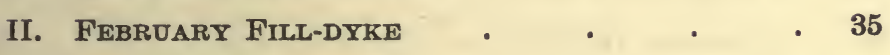

III. A March Salmon . $\quad$ - $\quad$. 46

IV. APRIL IN NoRth Devon . $\quad$ - $\quad$. 59

V. A Wiltghire Water-meadow . • . 63

VI. The First DRy-Fly DAY • . . . 73

VII. ON THE ITCHeN, IN MAY • • • $\quad$ - 78

VIII. A WEEK-END IN WILTSHIRE • . 97

IX. A MaY-FLy DAY • . . . 103

X. An Etening Rise • . . . . 112

XI. SEA-trodt in the Shetlands . . 121

XII. "MY ENEMY" . . . . . . 138

XIII. A Fisherman's Fall . . . $\quad$. 147

XIV. A Grayuing Day • . . . $\quad$ • 155

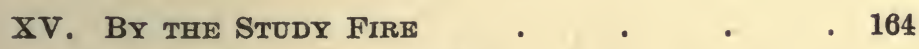




\title{
PART III
}

\section{ANGLING ABROAD}

\author{
I. An Albanian Trodt Stream \\ II. A Natal Trout $\quad$. $\quad$. 186 \\ III. Sea-fishing in Simon's Bay $\quad$ - 193
}

PART IV

\section{HOLIDAYS AND A WAR MEMORY}

I. Adgust in North Devon a a a 203

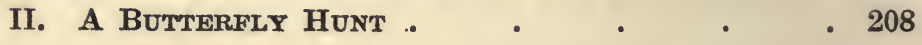

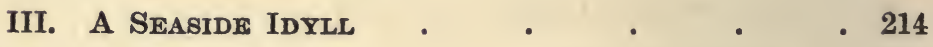

IV. A WAR MEMORY $\quad$ - $\quad$ - $\quad$ - 218 
PART I

\section{INTRODUCTORY}





\section{I}

\section{PHILOSOPHIES OF A FISHERMAN}

GISHERMEN are lucky folk in these days. Their standard is not a money standard. They envy not, as a master of their art once said, those who wear better clothes than they do, or those who have better food or bigger houses; they envy him, and him only, who catches more fish than they do. Really keen fishermen are seldom rich. For myself, I pity affluent youths, with a love of fishing in their souls, who catch their first trout before they are ten, their first salmon in their early 'teens, and their first big trout with a dry-fly-the most difficult feat of all-before they are twenty. Success has come to them too young, and its joy depends so much upon the work that leads up to it, the infinite labour, the many blank days, the moments of despair, and all the difficulties to be overcome. I once knew a very wealthy man who had kept his sense of proportion true and well-balanced. He under- 
stood fishermen. He lived in a beautiful old place in the Test Valley, and was one of the most hospitable men I have ever met. Those of his friends with so little soul as to be happy indoors on a June evening could fare sumptuously in the great dining-hall, in fine apparel, upon all the luxuries which wealth could provide; for the fishermen of the party the butler spread a light repast outside the front door, on the door-mat.

"I'm sure I should never care for fishing; I haven't got the patience." How many times in his life has every fisherman heard those words from a friend? You cannot explain things to such folk. Sir Edward Grey (as he was when he wrote his book on fly-fishing) gave an answer to that question: "People talk sometimes as if a sort of still, slow patience were the great quality experienced by angling. It ought much more properly to be called selfcontrol, and if another quality essential to success be added, let it be endurance." Those are the qualities of fishermen and of philosophers, who look into the depths of affairs and are not misled by the bubblings and boilings on the surface. Fishermen, like philosophers, are rich in contentment. They wear comfortable old clothes and the best boots. They love 


\section{PHILOSOPHIES OF A FISHERMAN 17}

their fellow-men individually and avoid them in mobs. A mob is often an evil thing, ignorant, prejudiced, easily led by an appetite to slaughter or destroy, far more prone to shout "Away with him!" than "Hosannah!" Taken individually, its every member-if you can only get him to yourself-is a very good fellow, better in many respects than you are. Taken collectively, a mob of men is capable of any enormity. For instance: there was talk some time ago about a "Union" of honest and kindhearted men starving a whole nation into submission because of some petty question as to how many months should be allowed for discussing a question of wages. Is it possible to imagine any individual in that Union deliberately starving man, woman or child in order to attain his ends, be they just or unjust ? The thing is inconceivable. It was talked of seriously as a praiseworthy and desirable procedure, if carried out collectively. No. Humanity is not at its best in crowds, so fishermen know better than to mingle in them; they place too high a value upon friendship with their fellow-men; and, if friends fail, they are happy alone, trying to learn a little about Nature's laws. Izaak Walton is their prophet; he lived in times of turmoil and of civic strife, 
but throughout them he lived at peace with himself and in harmony with Nature; his philosophy and love of angling have for centuries sweetened the lives of many, long after the hatreds and bickerings of his time have worn themselves out. Charles Kingsley, again, a keen fisherman of another and more strenuous type, lived in times of war and of riots; his philosophy of life stood him in good stead, and his precepts and example have brought peace to many virile souls struggling with the problems which darkened his own youthful days. But fishermen do not sermonize. They would have no influence at all in the world if they did. As it is, they have too little.

There is a chalk-stream hereabouts, and the grayling are rising: the autumn tints are more gorgeous to look upon than even the Victory Medal ribbon, and far more softly blended. The mere sight of the gentle flow of the clear stream would make the most rabid fighter for his own rights and privileges feel at peace with all mankind.

I had the good luck myself not to have been one of the affluent youths. I caught my first trout when I was about thirteen, my first salmon when I was over forty, my first three-pound trout on a dry-fly when I had reached the ripe 


\section{PHILOSOPHIES OF A FISHERMAN 19}

decrepitude of "present day." That triumph occurred in this same stream, during a short holiday snatched from those strenuous wardays that seem so long ago. What different days those were, in these parts! The sky in this valley was filled with the "cavalry of the clouds," training for oversea service. The country lanes were dotted with the hospitalblue of the wounded, who had learned new life-values in the great conflict and stood first in the public estimation. Money was of little moment. The folk who look at the swirlings on the surface of our national life, and do not think of the deep waters below, would have us think that we have lost our war-time goodfellowship, that we cannot face the future without an unseemly scramble between different classes to best each other, when only physical strength and ruthlessness will tell and the weakest will go to the wall. Fishermen are not so foolish. It takes all sorts to make a world and a good many pike to spoil a good troutstream. 


\section{II}

\section{MY FIRST TROUT}

TS a fly-fisher born or made, or both ? I think

1 that I was both. My first memory of living fishes takes me back to a terrifying walk, at the age of four, along a jetty, with planks wide apart and a view between them of clear green sea-water and little fishes swimming amongst branches of seaweed, swaying with the tide. Then a long sea-voyage, and a whole day spent at anchor at St. Helena. It was a baking-hot day, the sun blistering the pitch caulking between the deck-planks; but lying on those warm planks, I could see the calm sea through the hawsepipe and jelly-fish innumerable floating in the clear water. No one could get me away from that hawse-pipe. I had secured a reel of cotton and a bent pin, baited with gingerbread biscuit, warmed in a hot little palm and softened by the sea air. Nothing would persuade me that the morsels would not be as succulent to the taste of a jelly-fish as they were to my own : I 
cherished that illusion during the whole time we were at anchor.

Then a gap of many months in my fishing experiences. Next comes a memory of being taken for walks along the tow-path of a canal, constantly inspired by wonder about the mysteries of living fishes under the surface. Once I saw in the muddy water the dimly outlined form of something, probably a roach, and I longed passionately for a rod and a red-topped float to watch with never-satisfied faith, as I had once seen a man so employed on the banks of that canal. I pass over the realization, a year or two later, of that longing, and the capture, after many days of patient watching, of an evil and bloated-looking little fish taken on a leathery morsel of limpet from a rock-pool on the coast of South Devon; and then, after a few more years, came the day.

I can see myself now, desperately proud of a huge fishing-basket strapped over my shoulder and containing a packet of sandwiches, a slice of cake, an old leather flask fitted with a cup and filled with weak sherry and water, and, greatest joy of all, an old fly-book with parchment pages and cover of russia leather, smelling deliciously. I was spending a summer holiday with an uncle in Glamorganshire, a fine old 
sportsman who gave me the first chance of seeing real country; I had had the great misfortune to spend my childhood in a town. On the great occasion it occurred to him to entrust to my care a ten-foot greenheart fly-rod, made by Farlow, and, I think, about thirty years old, with a hollow butt to contain the spare top. I had no landing-net. Every step of that walk -it was about fifty years ago-comes back to me now. First a short-cut across a grass field and through a gate to the main road near three Scotch fir-trees. Then about three-quarters of a mile along a dusty road, soft to the foot, and then, at last, the trout stream. It was the Ewenny, and I had leave to fish the Ewenny water. There was a little pool below a hatch, and above the hatch the main stream, with its level raised by an embankment. Both pool and stream were ruffled by a gentle up-stream breeze.

With infinite care I had managed, with the help of my uncle, to attach three small flies to a cast of gut of a thickness that I should not dare to offer to the trout of this generation. This cast I remembered to soak carefully, and made it fast to an old-fashioned plaited silk and hair line, with occasional ends of horsehair sticking out where it had become worn: an abomination in these days, but a delight in 


\section{MY FIRST TROUT}

those unsophisticated times. The reel was a " multiplier" of an ancient design, with a small drum and prominent handle on a long spindle. First came the thrill of excitement over the first cast. I had had a lesson or two in casting a fly from the gardener's boy (a confirmed poacher), and I managed somehow, with the wind in my favour, to get the line out and the cast and flies to fall (in a bunch) on the water. A few more casts, the line helped out every time by the wind, and then- But there is no language to describe the thrill of it. Something had hold of one of the flies under the water, and that something was giving wriggling tugs. 'The rod throbbed deliciously to the very butt; through the butt and through my wrist and arm those throbbings passed through nerve and brain, seemingly to my very soul. Two or three seconds in doubt what to do, and then the memory of a word recalled from a book on fly-fishing, the word "strike" - a word that has cost many young fishers many fish and much expensive tackle. I "struck," and far behind me on the long grass fringing the millpool lay, struggling, a four-ounce trout. There had never been such a trout. Its head was small, its body of a fatness adorable, gleaming like copper above and like gold below. Its 
spots were scarlet, of the scarlet of poppies, rimmed with white and set off with other spots of black. It was my very own.

That was a wonderful day with the trout; in fifty years I have never known another like it. Nothing seemed to put them down, and nearly every one of them took the same fly, a yellowish-green silk body and a soft grey hackle, with no wings. I put one up as a dropper and one as the tail-fly, with a coch-ybondhu as the other dropper, and during the day, my first day's fly-fishing, in a clear stream, I caught $6 \frac{1}{2} \mathrm{lb}$. weight of sturdy little trout, mostly from four to six ounces, but one or two much larger. I should say that one of them weighed ten or twelve ounces, or thereabouts, and nearly all of them came out of one tiny little pool and about fifteen yards of the stream above. Once I had two on at a time. The droppers were fastened to the cast with oneinch loops of thick gut that would send the trout of these days away full speed to their weed-shelters, and I must confess that I cannot claim to have caught my first trout-he insisted upon catching himself. There was one that day that did not. Something took hold deep under water, and to my dismay I seemed to have no control over its movements. In a 
frenzy of excitement I threw down my rod, seized the line and pulled with my hands. There was a commotion-and the cast broke, just above the tail-fly.

In the light of the experience of after years I should say that I thereby lost a sewin of about two pounds weight, freshly up from the sea.

Tired out in body, but exultantly happy, I found my way home to tea, stopping twice by the way to take the trout one by one out of the basket and lay them on the dusty roadside grass. I washed them carefully at the scullery tap, and then the final triumph, as they lay on a big dish, nearly slithering off it as I carried them to the study for my old uncle's inspection-the biggest carefully arranged to show up, and, in the place of honour, on the top of all, my first trout. 



\section{PART II}

A FLY-FISHER'S YEAR 



\section{I}

\section{THE TURN OF THE YEAR}

W INTER is a time of suspended animation for the lover of streams and running water. For a dry-fly fisher especially, if the little infirmities coming with advancing age prevent him from enjoying a grayling day after the last glories of autumn have passed away.

In the words of that delightful poem of Edward Fitzgerald's with which Mr. E. V. Lucas begins his Open Road:

When such a time cometh,

I do retire

Into an old room

Beside a bright fire,

and settle the affairs of the nation with that mighty weapon, the fountain-pen of the armchair critic. Some day, real life will return; to quote again from the same source: 
Thus, then, live I, Till, 'mid all the gloom, By heaven! the bold sun

Is with me in the room,

Shining, shining !

Then the clouds part, Swallows soaring between;

The spring is alive,

And the meadows are green!

I jump up like mad, Break the old pipe in twain, And away to the meadows, The meadows again!

That man must have been older than I am. Or perhaps there was no one to stir him out of his study and to tell him sooner of the turn of the year and the sunshine without.

The turn of the year comes long before the swallow. Some say that it comes on that dreary day in December when you know that the days really do begin to lengthen, although you shave (if you do shave) by candlelight, and even Christmas is not quite yet. No; the turn of the year is some time after Christmas. When is it? At New Year? Not quite; but in these parts, if the weather is mild, there is an indication some time in January that the turn is coming. Little crimson stars show on the hazel-nut buds, waiting 


\section{THE TURN OF THE YEAR}

to catch the pollen from the lamb's-tail catkins hanging in tassels above. There is a hazel in the corner of my garden outside the study, and I make a daily pilgrimage thereto in the hope of seeing those little stars of promise. They came early in January this year. So did the aconites, periwinkles and snowdrops; so did the yellow crocuses-very early indeed; they were fully open in the bleak sunshine of one day in late January, a record for these parts. And in the second week in February our first daffodil was fully out in a sheltered spot in the garden.

Once upon a time, when I lived in a town, in my youth - Could not some philanthropist so arrange matters that every town boy and girl should spend at least one whole year in the country, amongst sympathetic folk inspired by some knowledge of nature, to see all the changes of the seasons? The "nature study" creeping into our scheme of national education for the youth of cities is a step in the right direction, but a poor substitute for the real thing. To get back to my "once upon a time": I used to imagine that there was no colour in a winter landscape, except brown. Trees, fields, hedges and roads, all seemed to me to be brown in winter during the fleeting 
glimpses I had of them, until the time when the marsh-marigolds began to blaze at me in the water-meadows. Now-but I must begin to-day, the turn of the year, from the beginning.

There was something indescribable in the air that came into open bedroom windows early this morning. Something that made me want to be out of bed and out of doors. Very different from the usual winter-morning feeling of resentment at having to leave a warm bed, and of envy of dormice and such-like folk who are credited with spending their whole winter in warm sleep. The feeling was forgotten with the beginning of the morning's task in the study. Newspapers to be studied, to keep abreast with public affairs for the sake of an article thereon, for which an Editor is clamouring. Letters to be read and answered; accounts, bills, and so on. Then a settling down to the day's work, the article itself. The writing-table in the little study faces away from the morning sun, and I work contentedly for a time, when-enter Herself, from the garden, by the French window facing east. The sunshine enters, too, no longer cold winter sunshine, but life-reviving sunshine. "Why don't you leave that, and spend the day up the valley ?" 


\section{THE TURN OF THE YEAR}

The Editor's visage fades from my remembrance. He is human; he would drop his blue pencil, even as I drop my pen, if the poor fellow could only see the sun over the chimneypots as I see it over the trees. There is something different, some new life in the air; it smells of new life. The turn of the year has come, and "indoors" is stuffy and impossible. I must see that valley again.

No colour in the winter months? When I get to the valley I find the elm-trees spangled with scarlet specks in the sunshine (in my youth I never knew that elms had red flowers!) and the beech woods and birches a soft purple, the withy-beds blazing orange and red. Almond-blossom is out in a cottage garden. In one sheltered and sunny spot a pear-tree is just showing signs of flowers : no pears from that tree! There are bad times ahead, bitter east winds, probably, and snow and sleet, before the real spring comes. But the turn of the year has come, and that means that the sun will gain daily in strength. As in the late war, creative power will get stronger after every onslaught of hate and destruction, and the sunshine will grow constantly warmer until "Break-a-pipe day." That is the name by which we call the day described by Edward 


\section{MOSTLY ABOUT TROUT}

Fitzgerald above. Then, equipped for flyfishing, we'll go off to his "Meadows in Spring" to meet the swallows. For the present we will keep to the road; the water-meadows look cold and uninviting. But the turn of the year has really come. The soft silver-grey "pussy-cat" catkins are showing already, the "palms" of the country folk; soon they will be yellow, powdered with golden pollen. Then the marsh-marigolds will bloom again in the water-meadows.

These words may be read on a bitter day, with cold winds and driving snow or sleet. But the sun will win. The turn of the year has passed. 


\section{II \\ FEBRUARY FILL-DYKE}

T WONDER whether there is a close-time 1 for pike, and what the penalty is for disregarding it. I suppose that as a fisherman I ought to know, but there might just as well be a close-time for rats in a wheat-stack as for pike in a trout-stream. For all I know they may be out of season in February, so perhaps I had better not mention the name of the river referred to in these notes of a February day, lest I be pursued by those whose business it is to deal with breakers of the law. In such matters the activities of upholders of the law are confined to their own fishery districts. It is not their business to pursue malefactors beyond those limits. The main point is that the pike must be got rid of by every imaginable device, and they seem to take better in these parts in February and March than at any other time of the year. Spinning for pike in fast-running water is great 
sport, when they are taking. It is a chilly business when there is nothing in the way of excitement to warm one, when the watermeadows look dreary in the grey light, and constant casting without result gets more and more monotonous as the hours go by.

February generally justifies its name of filldyke. Many of the meadows are flooded for a time, and even for the keenest of sportsmen of mature years there is not much fun in splashing through them under such conditions, with every chance of stumbling into a concealed deep channel where icy-cold water will pour down one's leg over the tops of long wadingboots. The floods subside towards the end of the month, enough to show up the riverbank, always the driest part of the average water-meadow. When that happens and a fine day comes, it is high time to put up the pike rod. There is a certain white-railed bridge about two miles above this old cathedral city (I do not think that is enough information to afford a clue to its whereabouts). About three-quarters of a mile above that bridge is a huge boiling hatch, very deep, with a heavy flow of water. Above that hatch the "happy valley" begins, a valley of little villages about a mile or so apart, and between them some 
really good trout water. The river there is netted for pike and other coarse fish, for the sake of the trout. Below the hatch the pike have it all their own way as far as the city, in which for some curious reason the trout flourish again. There are always a few big ones to be seen under each of the three or four bridges, and generally a row of good townsfolk leaning over the parapet to look at them. They remind me of the fisherfolk in a certain village on the Cornish coast. The saying in those parts is that you can always tell the men of that village because the elbows of their coats are worn out by leaning on them over the low wall of the little breakwater. The wall of the breakwater by the next village is lower, and the men who dwell there can be distinguished by inspecting the seats of their trousers. But we will leave all thoughts of the townsfolk behind us, after buying a hot mutton-pie at a pastry-cook's and wrapping it up in a cloth to take with us, ready for eventualities. A small thermos flask full of hot soup is not a bad thing to have with one, as well, on a February day. It is a grey, cold day, with a cold wind blowing, and there is no sense in not being supplied with creaturecomforts, in case, there should be a blank day 


\section{MOSTLY ABOUT TROUT}

in prospect and a long walk home with an empty bag-much more tiring to carry than a full one, after a long fishing-day.

I wish that I was better at this casting business with a light wagtail bait and a wind blowing. It is so difficult to get fly-fishing out of one's head and to realize that it is a different art altogether. I remember that I used to find it fairly easy from a boat, with a nice flat board to coil the spare line on before swinging out with the bait, but what with grass and mud and old rushes and pools of water along the banks, that way will not do, so, years ago, I provided myself with a very extravagant contraption in the way of a patent reel which runs free if you press a little trigger, less freely if you do not, and with a heavy check on the line if you touch another thing. I suppose that it would be all right if one fished for pike every day, and it would come naturally to touch the right thing instead of the wrong one, but, as it is, I sometimes in casting keep the free-wheel arrangement on after the wagtail has dropped in the water on the other side of the river (or wherever else it may have fallen after a bad cast). If you press the trigger for a fraction of a second too long, the drum goes on free-wheeling and overruns yards and 
yards of line. It takes ages and much patience to set matters right, and meanwhile the wagtail bait, bristling with triangle hooks, sinks to the bottom and catches in a snag or a weedroot before you can reel in. Probably the trouble is in the word "casting," because what you really do if you can is to swing the bait smoothly out, with only just enough force to send it where you want to, slip your finger off the trigger the instant, or just before, it touches the water, and then reel in slowly at once to take up any slack line and let the current spin the bait. It would all be easier if I used a lead, I suppose, but the river is not very deep, and as a pike's eyes are on the top of his head, I have a notion that he sees things better if they are well above him in the water. But I do like good big, bright metal spinners to keep the bait spinning well and showing good flashes as it spins. I find the wagtail (which is just two flat strips of rubber) painted reddy-brown and gold outside better than the pattern painted blue-and-silver. Both are painted red inside the strips.

Well, here we are at the river, and it certainly is good to see running water again and to have a rod in one's hand at last, even if not a flyrod. I only wish that I had a telescopic gaff, 
as a long-handled one will get between one's legs, somehow, wherever it is slung. All this sounds rather critical and not in holiday mood, which only means that we have not got into things properly yet, but we soon shall. In a few minutes we get an extraordinary bit of luck: a kingfisher flits by in a flash of blue. We put one or two snipe up as we go through the water-meadow and a wild duck as we get near the bank. Then, as we wander away from the road, comes complete solitude: not a sign of life anywhere; at least, none visible or to be heard. With the silence and solitude comes peace, and soon keenness, as the bait goes out and is wound in past a likely place for pike. Time after time it goes out, swings round with the stream as I wind in slowly, dwelling under the near bank, and leaving the bait spinning under water till close to my feet. Sometimes a pike will follow it all the way round and only take at the last moment, and here and there are patches of reeds along the bank and likely spots for pike to lie amongst them.

So it goes on for an hour or two: swing across, reel in, recover, swing across, reel in, recover, monotonously and with no success, until the face of the water looks blank and as 
if there can be nothing alive behind it. Then

a convenient rail to sit upon is suggestive of a rest and luncheon. One weak spot of watermeadows for the fisherman in need of rest is that you cannot sit down in them, and it is no use carrying a shooting-stick or campstool, because it sinks in the mud if you try to use it. Hot soup from a thermos is good. So is the mutton-pie, still warm; but before it is finished a subtle change seems to come in the air, or the light-quite indescribable; but the effect is that instead of the river looking as if it contained nothing alive, it looks as if its slightly coloured waters concealed many great fishes. Such times are not to be spent in feeding; the mutton-pie, with a bite out of it like the one in the Mad Hatter's slice of bread and butter, goes into the napkin again, and into the pocket, and I resume fishing, full of hope and too keen to wait even to fill a pipe.

I wonder whether there really was a change in the air or light, or whether the hot soup refreshed a tired brain and muscles and made me fish more carefully and better. The line goes out much better now, and drops each time a few inches short of a long reed-bed on the other side, about a couple of yards further 
down-stream each cast. About the sixth time there is a tremendous commotion. That is the fun of pike-fishing; they do come with such a furious rush when they are feeding. The strange thing is that they do not always hook themselves on one of those heavy triangles spinning with the bait. Whatever views one may hold about "striking" with trout, there is no doubt about the advantage of a real good strike, making the taut line rattle in the rings of the rod, when you are dealing with a pike. It drives the steel well home into pretty hard substance, and the finer the steel is for the purpose the better, as it means a pretty severe strain to get it in over the barb. There is no danger of a break with a fine twisted-wire spinning trace like there is with a cast of gut. Playing a pike seems different from playing any other fish. There is a certain fierceness about the struggle. A note of furious rage seems to communicate itself from the fighting pike up the line and down the rod to the butt, and whether you can see the predatory fish or not, you imagine his malevolent-looking head under the water and look forward to closer acquaintanceship with his vicious rows of teeth and snapping underhung jaw. The struggle is so 
violent and uncompromising for a few seconds that it reminds me of the highly imaginative description by a French journalist of a combat between King George and a salmon, in the days when the Franco-British pressmen were engaged in writing up each other's prominent personages by way of keeping going the good feeling between the two countries at a critical moment in the war. Here is a literal translation; it reached me in Whitehall when I had something to do with co-ordinating "propaganda" (hateful word) on behalf of the Government. Needless to say, the article was intended to be most complimentary to His Majesty, and the writer made what he thought was the best use of his lively imagination with that end in view :

$\mathrm{He}$ is an angler of the first force, the King of Britain. Behold him there, as he sits motionless under his umbrella, patiently regarding his many-coloured floats: how obstinately he contends with the elements! It is a summer day of Britain - that is to say, a day of sleet and fog and tempest. But what would you? It is as they love it, those who would follow the sport. Presently the King's float begins to descend. My God! but how he strikes! That hook is implanted in the very bowels of the salmon. The King rises. He spurns aside his footstool. He strides strongly and swiftly towards the rear. In good time the salmon comes to approach himself to the bank. Aha! the King has cast aside his rod. He hurls himself flat 


\section{MOSTLY ABOUT TROUT}

on the ground on his victim. They splash and struggle in the icy water. Name of a dog! But it is a braw laddie! The gillie, a kind of outdoor domestic, administers the coup de grâce with his pistol. The King cries with a very shrill voice, "Hip, hip, hurrah!" On these red-letter days, His Majesty King George dines on a haggis and a whisky grog. Like a true Scotsman, he wears only a kilt.

Well, my pike was "struck" with the same vigour as the King of Britain's imaginary salmon, and as a result he came, or was compelled to approach himself, to the bank, and was there dealt with by the gaff and hauled into the grass, a long and lanky fish, green and gold. A tap on the head, and the use of a stick to keep open the rat-trap of teeth, enabled the deeply embedded triangle to be removed without disaster; the feeling of having caught something, the first fish of the year, put quite a different aspect on the greyness of the landscape and the leaden sky.

During the next hour two more good-sized pike were seen following the bait round, and two small jack took it and were landed; also, alas! a trout of about three pounds, which refused to show any vigour for some time after its unpleasant experience with the triangles, when gently returned to the river. But the water there was sluggish; there might still 


\section{FEBRUARY FILL-DYKE}

be a chance for him, so I lifted him out, ran to a little rapid side-stream, held him upright in it with the clear water running through his gills, and he soon made off as vigorous as ever, seemingly none the worse for the disaster.

Then came the time to notice the fact that rain had been falling heavily and drenchingly for some minutes, and, as another Frenchman said, "too much is enough." The walk home was unpleasantly wet, and clothes were soaked; the first little trickle down the neck and the feeling of soaked knees are the worst features of wet walks, but as long as you keep going they do not matter. They are not a bad preparation for full enjoyment of a hot bath, a change into warm, dry garments, and hot buttered toast for tea, followed by a pipe over a favourite old book by the side of a fragrant wood fire in the study. - February can go on filling the dykes as much as it likes. Then there will be all the more water to fish in when the trout season opens. 


\section{III}

\section{A MARCH SALMON}

THOSE who aspire to take salmon on a

1 fly in March must belong to one out of three categories. They must live in Scotland, on the east coast for choice, or they must be born with silver (or, rather, golden) spoons in their mouths, or they must have some exceedingly kind friend who had that good fortune. On the principle that even the best of good sport in the world should not come too often for its most vivid enjoyment, I should say that those who come within the third category, as I do, get the most enjoyment out of a day's salmon-fishing in a good spring river in March. The excitement of anticipation is tremendous, especially if you have fished the same river before and the surroundings of every pool are indelibly fixed in your memory. I remember very well my first chance of getting a salmon. It was in the Dee, in late summer, and I was at Aberdeen, on my way back from 


\section{A MARCH SALMON}

the Shetland Islands. A friend of mine, without my knowledge, had written to his brother, who had a rod on a bit of the Dee, to suggest his putting me up on my way through and giving me a chance of fulfilling a salmon-fishing ambition cherished for about thirty years, apparently never likely to be fulfilled. It was a fine experience, and impressed me with its big scale after ny trout-fishing experiences. There was no wind, and plenty of stream to pull the line and to fish the fly, so conditions were favourable for my first experience with a big rod. My friend left me alone for an hour, after telling me the best casts. During that time nothing took my fly, but I had the thrilling experience of seeing what seemed to me like a porpoise roll over my line once, just as I recovered it. Maybe the salmon intended to take, and maybe he failed to do so because I did not let him have a chance. Then we went in a boat for a short distance, having a few casts by the way, and I was sitting down in the stern, reeling in my line, when, suddenly, there was an unexpected tug. It did not seem to me to be a very heavy one, and I did not realize what had happened until I reeled in more line and found that the fly had gone, the cast broken just above it. I asked whether 
there could have been a stake or other obstruction in the water just there, but was told quietly there were none, and, by way of comment, that the salmon taken in that pool at that time of the year usually weighed about $30 \mathrm{lb}$. There is no need to recall any more of that day's experience !

There is a certain Mecca of salmon-fishers in early spring, a much smaller river than the Dee, on the east coast of Sutherland. Several times have I been bidden there, and never will those experiences be forgotten. First, the anticipation. It would take a whole book to describe that alone, if I described it fully. Then the journey. Such a journey! The dinner at Euston, the friendly train-conductors, one of whom I knew as a kindred spirit in fishing lore. The non-stop run to Rugby, the longing for sleep to come, with the promise of waking up in the wonderful air that makes Scotsmen what they are, the sleepy realization of achievement at the sound of "Car-r-stair-r-rs" being called on a platform in the night, the vast emptiness of Perth station, the sleep afterwards, with the determination to shave while the railway line is still mounting the gradient, so as to avoid cutting oneself severely as the speed increases 


\section{A MARGH SALMON}

on the down-grade. Then the string of lochs and view of snow on the mountains, the larches, birches and dark-looking heather near the line. The brown, dead bracken, snow-laden. Then Kingussie. Travellers to the North of Scotland can be divided into those who know that by giving notice at Euston you can get a good breakfast-basket at Kingussie and those who think that you must wait for the change at Inverness. The former, at the summit of their joyful realization that the morning of arrival in Scotland in spring has really come, find themselves confronting a basket containing a really hot breakfast of bacon and eggs, hot tea, scones, oatcake and marmalade, all wrapped in clean paper, and all of the best. They have time for a smoke, and then they change trains leisurely at Inverness. The latter arrive there in a hurry, scramble for a hasty hotel breakfast, and then hasten to the platform for the northern line, with just time to find a seat and possibly none to get a newspaper. Not that that matters much. Who could read one, passing along that railway line up the northeast coast? There is one spot where the line leaves the sea and you get a glorious glimpse of salmon river, and then a view of a tree-clad gorge, with glimpses of coffee-brown rushing 
waters and an occasional deep, still pool. By that time you are so filled with the joy of life that, if you have the carriage to yourself, you have to get up and dance, to work off some of it -at least, I did, regularly, up to the very last trip, which was not so many years ago. Then, later on, the coastal bits again, close enough to the beach to watch the bird-life thereon, the oyster-catchers showing up conspicuously amongst the others more soberly adorned. And then the arrival. The moment has come, and not the least of its pleasure lies in the hand-grip of the excellent gillie who was with me when I caught my first salmon, and who treats me as if the years that have passed since my last visit were only days. Soon I feel as if I had never been away from "the strath." The little town, the roads, the old bridge and the river seem to have changed very little; the people not at all. By good luck I have arrived on a day when we have the beat nearest to the station. The river is in order, and we can start almost at once. Salmon-fishing is strenuous work if your muscles are soft and you use a big rod (mine is a greenheart, seventeen feet four inches, for spring work in heavy water), and it is well for the unfit on the first day to conserve all energies 
for the actual casting. Never shall I forget my first experience of sheer hard work and constantly disappointed hopes by that river. Salmon-fishing is always uncertain sport, however hard you work, and I put in about six hours a day with a big rod and heavy line, sometimes in gales of wind, sometimes with the weather side of my face and body plastered with snow, and that for twelve days, omitting the two "Sabbaths." Never one fish did I touch or even see in all that time, although I obeyed the precept that the one secret is to keep on at it, there being a better chance of a salmon taking your fly when in the water than when on the bank. Even luncheon was eaten when walking (almost running) from pool to pool. Then, on the eleventh day, the last chance but one, I confess that I was worn out, handed the rod to the gillie for a few minutes while I sat on the heather to eat my luncheon, and-he had a fish in two minutes! There was some joy in playing it and meeting the strength of a fresh-run salmon for the first time, but the thrilling moment of feeling the fish take, by far the best part of salmon-fishing, had been missed, and the glamour of that experience had been lost. Next day, the last of the holiday, I did get a fresh-run fish myself, 
and made the acquaintance of a kelt. The next year I did well, with an average of three fish every two days, and for some extraordinary reason I hooked two-thirds of them outside the mouth-why, I don't know; possibly because of trout-fishing methods, but it has always been a puzzle to me. My salmonfishing experiences have been few and far between, and I always thought that part of the game was a tremendous sprint for a mile or more, with the constant danger of a break; but in that river I have only known one fish leave the pool he was hooked in, and that one was a seven-pounder, foul-hooked, that took me for a welcome sprint over heather, down-stream, for about two hundred yards, on a very cold day. One other fish made a sudden fast rush, upstream, the instant he was hooked, and he played fiercely for some time. He weighed $18 \mathrm{lb}$. and was pronounced by experts to be a bull-trout. To my mind the horrible "jigging" in which some salmon indulge provides the most thrilling experience in playing them; it brings your heart into your mouth: it feels as if they were rubbing the gut against a rock or something, to wear it out.

But to get back to the strath on that first day of a holiday in March, with every sense 


\section{A MARGH SALMON}

keen, and the feeling that at every cast a fish may come. One did, on the occasion that I am thinking of, in the first pool. However keen you may be when salmon-fishing, you are keener as you approach a spot where you had a fish or a touch before than you are at other times. The best bit of that pool was about half-way down, and there, the first time down (taking the usual step after every cast), I felt a little pluck; it was no more. I made a heel-mark in the turf under the heather there, reeled in, and walked back again, waited for what seemed to be a very long time, and fished down to the same spot again. Every step nearer to the mark the excitement increased. One yard after I reached it, having almost abandoned hope, he came, was hooked, played, and landed within about nineteen hours of leaving London. A surprising bit of fortune, which few have the good luck to experience with March salmon in that, or any other, river; and it is wonderful how such luck sustains one for many days in the belief that a fish may come at every cast, whether disappointed for a while or not.

There is something virile about salmonfishing. The sheer hard work, the endurance, the facing of constant disappointment, and 
the occasional glorious reward of achievement. Then the strength and weight of the stream and of the fish all make for rejoicing in the struggle; and, above all, the pure air and the surroundings of rock, heather and birchcopse. The long-drawn-out nesting note of the curlew, "the most healing note in nature," as it has been called, the grouse in their early spring plumage, the snow-clad moors and the keen, clean air therefrom. The days of storm and wind and the interludes of bright warm sun, when everything seems to begin to throb with life after the long winter sleep. There is no place that I know like the North of Scotland in March for reviving youth and for clearing cobwebs out of the brain, and there is no finer setting for a struggle with a March salmon. Day after day you set out, full of hope and excitement; day after day you may return utterly worn out, with muscles aching with fatigue, not having touched or even having seen a fish, and it seems as if the very existence of salmon in that river was nothing but a tradition. The next day you start as full of zeal and energy as if there was no such thing as a blank day, and perhaps you are rewarded by some splendid experience. For instance: the weather perfect. The river in order. The 


\section{A MARCH SALMON}

best beat thereon, and the first access to the best pools offered by a kindly and unselfish host. A view, from the windows of the breakfast-room, of a hillside softly outlined by birch woods, delicately tinted in mauve and purple. A walk over springy turf to the nearest pool. Two fish in the first twenty minutes, inciting to supreme keenness without a trace of fatigue throughout the glorious hours that follow. Another fish before luncheon in the third pool, the second time over. Three silvery beauties to contemplate during the brief interval for luncheon itself, taken, perhaps, more leisurely than usual, with a sense of initial achievement, with unfished pools in prospect and hopes of further success. Two more fresh-run fish in the afternoon, both from difficult places requiring long casts never before achieved, and both affording moments of acute anxiety in the playing and in the landing. Five spring salmon in a day, six to the other rod, heavy baskets to load on the wagonette; and then the drive home together up the strath, past familiar scenes which recall former triumphs, absorbing in silence the beauties of moorland and copse, and storing up memories that make for life-long contentment.

I wonder in what quality success in salmon- 
fishing lies. Knowledge of the water, of course, goes a long way, but the gillie supplies that: he knows what the bottom of the river is like; you can only see the surface, which may help you with trout, but very little with salmon. I suppose that there is something in the selection of the fly; but there, again, the gillie comes in. I sometimes wonder whether he pays enough attention to the direction from which the light strikes the pool. I was tremendously impressed by a lecture I once heard delivered at the Camera Club, where underwater photographs of a salmon-fly swinging round in the current were displayed, showing the difference in its appearance when the source of light was before or behind it. In one case the fly "flashed" and sparkled, in the other case it showed dark, as a silhouette, whatever its colour might be. Then, of course, we must give points for skill in casting and in working (or not working) the fly, to give it the right appearance. I suppose that a long, straight line is the great thing in early spring fishing in heavy water, so that the pull of the line on the fly shall be applied as soon as possible after it is in the water. Thereby, by the help of the stream, more water is covered effectively. This, as I find from an old diary, is how, 
in 1914, I summed matters up statistically for one whose chances of salmon-fishing are occasional :

$$
\begin{array}{lccccc} 
& & & \multicolumn{3}{c}{\text { Per cen }} \\
\text { Luck .. } & . . & . . & . . & . & 50 \\
\text { Gillie .. } & . & . . & . . & . & 20 \\
\text { Flies and tackle } & . . & . . & . & 20 \\
\text { Skill .. } & . . & . . & . . & . & \frac{10}{100}
\end{array}
$$

Far above all else in salmon-fishing, as in war, comes persistent endurance in the face of discouragement. Persistent endurance is far easier to achieve in salmon-fishing than it is in war, because you are spared the long periods of deadly monotony. Every pool differs from every other, and itself varies from day to day with the weather and the head of water. You get a constant change of scene as you move from one pool to another, and fresh delight in the glories of familiar but always new surroundings. And if you mean to succeed, there is that one little bit of advice that transcends all others in importance: "Keep your fly in the water." For those on economy bent, either because of emptiness of pocket or of reluctance to deplete a full one, there remains the old precept: Never economize in gut. Be sure to use the very best. The feeling that 
58

\section{MOSTLY ABOUT TROUT}

one has worked one's hardest, and done all that was possible, consoles at the end of the blankest of blank days. In the knowledge that a fish has been lost, after much toil and strenuous endeavour, through cheap gut having broken, there is no consolation whatever. 


\section{IV}

\section{APRIL IN NORTH DEVON}

SUCH a gorgeous morning. Big fleecy $N$ clouds drifting across a bright-blue sky before a chilly north-west wind that troubles me not at all where I lie on a sheltered bank in the hot sun. The Torridge runs at my feet, slightly coloured by last night's rain, and on the opposite bank the breeze stirs and sways a belt of "wild daffodils. Beyond them a meadow, and then woods mounting up a steep hill-side, red and purple with elm-tree flowers and the tresses of birches. Here and there a patch of young larch, with just a shimmering of green appearing. The bird-life in these parts is wonderful. There is a tiny patch of grass outside the window of the little study where I sat writing after breakfast, and on the grass we spread the breakfast-table scraps. First came a couple of sparrows. Then samples of three sorts of tits. Then a cock chaffinch, glorious in his spring plumage, and then, greatest joy of all, 
two nut-hatches, very busy, but having just a moment to spare to perform a few gymnastics on a wee bush in the corner of the little grass-plot. After a glimpse at the spoil, one of them seized the biggest morsel, the other the next in size, and away with them in a hurry to their food-hoarding hole, of which we know the whereabouts in a friend's garden. Then a greenfinch-and all this within the space of ten minutes. I will pass over the birds seen in the primrose-banked lane leading to the river. From the lane runs a footpath through a wood, a little brook babbling by the footpath to run a wee mill just before joining the Torridge. On reaching the river the footpath turns up the river-bank, and between that spot and where I am lying I saw three kingfishers, the first two showing only the coppercoloured underside, as they had turned upwards when I saw them, but the third I had a full view of from above, as the sun shone full on his flashing 'blue back. There are three green woodpeckers calling afar off, and one is tapping in the wood opposite; but none of these have I seen this morning.

The most uncommon sight I have kept to the last. On the sky-line the softness of colouring of the trees in the wood is merged 
into softness of outline. In the sky above are two buzzards. "Yesterday," said my companion, "I could see six when I was fishing near this spot." I wonder how many there are in the whole of the country. They are the only ones I have ever seen myself. "Watch them doing stunts," he added. Suddenly one came circling down in a graceful curve, floating on its side, with wings nearly vertical. "An Immelmann turn," he added quietly. I thought of his experiences in the war. Sandhurst as a cadet for a few months, two years in the trenches, with a good line regiment, the Second Battle of Ypres, Loos, the Somme-battles too numerous to mention and shell-fire and snipers all the time; then a transfer to the air, and all the varied experiences that go therewith, described by many pens; now a captain in the Royal Air Force, wearing the Military Cross and the 1914 Star. As he is convalescing after a bad crash, I do not pursue the subject, but contemplate the row of twenty-three Devon trout glistening on the grass between us, and then pack them in the basket as he wades in to finish his day's fishing, while I stroll homewards along the bank, passing as I go a rival fisher, a dead heron caught by the wing on a bit of barbed-wire fence, and seeing 
a salmon jump in a deep, turbulent run at the head of a glorious pool.

What a holiday! Yesterday, a run in a car down the Torridge Valley to Bideford and Barnstaple. The historic bridge over Torridge at Bideford. Appledore. The junction of the Taw and Torridge. The faint blue outline of Lundy Island in the distance out to seaward. Bideford again, on the way home, and a few minutes spent in the old church, with the evening light making the brilliant eastern windows sparkle like jewels in contrast with the dark interior. We had the good fortune to have rested in the church at a time when some unknown lady was practising upon the wonderful organ and filling the church with the sweetness of sounds indescribable as the colours of a sunset sky.

To-day's delights I have described. Tomorrow, London again, for work at the hub of affairs, in a Whitehall office where the threads of policy are collected. But besides the red and black ink, the stationery, and the traditional red-tape, there will be on my table a consoler, a bunch of wild daffodils from the banks of the Torridge, and the memory of the North Devon holiday will long survive them. 


\section{V}

\section{A WILTSHIRE WATER-MEADOW}

TN the cold weather the water-meadows are 1 for the vigorous and healthy, who, with gun, rod or pike-spear in hand, can enjoy splashing through their flowerless solitude, and the thanks of the fly-fisher are due to those of them who spend the short hours of daylight waging war upon pike, which thrive beyond belief in Wiltshire chalk-streams, unless they are relentlessly kept down. Some time in April the warm sun restores the meadows to all their golden glory. This is the story of such a day. It came this year after many weeks of streaming rain and grey, gloomy skies. A few soiled marsh-marigolds, lying abandoned by some child in the muddy road, were the first signs of its coming. Then, soon afterwards, word of their flowering must have been passed round amongst all the school-children, for we met little troops of them on the wettest of days, muddy, dripping and dishevelled, but flushed and happy, carrying 
the flowers in armfuls to brighten the windows of the dismal little streets on the outskirts of the neighbouring town. The steady downpour went on persistently for several more days, until it seemed that skies always had been, and always would be, grey, and we should never see the sun shining on the water-meadows again, or the trout showing up in the crystal clearness of the little stream that meanders through the rich grass. Then, quite suddenly, came the day, warm and sunny.

Some fortunate folk can look up at the sky on such a day through the interlaced twigs of an apple-tree, covered with just enough palegreen leaves to set off the beauty of clusters of pink-tipped blossoms. Some of these clusters show against patches of brilliant blue sky, some against grey or white clouds with deliciously soft outlines, so different from the hard clouds of a cold winter sky. All the time, pink and white petals drift gently to the ground, shaken off the flowers by little gusts of air coming from various points of the compass. I am one of those fortunate folk this morning. There is just such a tree on our lawn, old, gnarled and unpruned; the first glance at the sky through it, and the note of the cuckoo sounding from a distant copse near the river, send me off 


\section{A WILTSHIRE WATER-MEADOW 65}

hastily in search of warm woollen stockings and long, heavy rubber boots. Middle-aged fishermen must face those sore handicaps to enjoyment of a walk in water-meadows, even if (perhaps because) they have scorned such coddling in their younger days. The call of the meadows is now irresistible. There are limits to the human powers of resisting temptation, so the fly-rod is left behind; the big trout are not yet in the best of condition, and a few of them may possibly be rising. A long troutfishing season, with all its possibilities, lies ahead, and 'we can afford to be patient. But a coil of fine wire rests in my pocket, in case a pike should show himself; they always do when there is no form of killing-tackle handy.

The way to the river takes us down a steep footpath, slippery with chalky mud. Every step needs care, and eyes must sometimes be fixed on the ground, though they constantly wander to the boughs and twigs interlaced overhead, their delicate tracery softened, but not hidden, by the green shimmer of young leaflets. A wood-pigeon is crooning in one of the trees, rooks are cawing from a neighbouring colony, and from the distance, across the valley, comes the occasional note of the cuckoo, not yet as aggressive and monotonous as it will be later 
in the year. Soon we come to an ancient stone bridge, where children are leaning over the low parapet, dangling bottles and bread-crumbs to catch minnows. A little way above the bridge stands a mill of old red brick, roofed with seasoned tiles that are tinted in all conceivable shades of green, brown and red. We pass along a grass-grown pathway through a straggling garden, gay with wall-flowers and forget-menots. On one side is an old orchard, with long grass, dotted with daffodils. On the other side is the stream, racing out of the mysterious depths of the mill itself, from which comes the chumping sound of the revolving wheel. We go through a dark chamber over the hatch into the daylight beyond, pausing to watch a big trout, poised only a few inches above the boiling turmoil of the mill-race, and holding his own against the current by slow strokes of a broad, square tail. A beauty, noted for future guidance.

Then a muddy track takes us through a copse above the mill. One big clump of marsh-marigolds is growing on the edge of the water, the stream washing its roots; on both sides of the track grow young dock-leaves and nettles that will be waist-high a few weeks hence, and here and there, close to the bank, the water-avens shows its graceful, drooping heads, with their 


\section{A WILTSHIRE WATER-MEADOW 67}

red-purple hoods and bright yellow stamens. Here and there is a delicate lady's-smock, and a few daisies. Amongst the dock-leaves rises occasionally the fat stem and pale mauve head of a butter-burr. What, by the way, has it done to annoy the botanists? Why is it called by one "the most pernicious of all the weeds that this country produces"? and the only evidence he produces against it is that it is "planted near bee-hives by Swedish farmers, on account of its early flowering." What harm does it do?' I have only seen it in this one muddy spot, where nobody wants to grow anything else, and the mauve heads, seen amongst the dock-leaves, are not unattractive.

The copse ends at the old wooden rail, and beyond it opens up what has brought me here, the first view of the water-meadows in glory indescribable, carpeted with masses of marshmarigolds. The whole valley is bathed in sunshine, and here is the spot to pause for a quiet smoke in the shade, thinking over battles fought with big trout in this meadow in past seasons and plans of campaign for the future. To-day we will reconnoitre, and it is time to leave the shelter of the copse, climb through the rails and into the meadows. The long boots, made for very different work in the 
Flanders trenches, keep me dry and warm as I flounder through shallow water, sometimes blundering into unfamiliar deep channels, sometimes sticking in muddy spots, always keeping an eye on the stream for signs of life.

This is a wonderful part for fly. Succulent little olives and some large grey flies that I cannot identify are floating down, poised lightly on the surface, especially round one spot where I hooked a monster last year, a deep, lightcoloured fish in the pink of condition. He was very lightly hooked, and the fly came away at once. I never saw him again during that season; the weeds were shaved off closely next day, the water fell many inches, and he fled from publicity. Now the water is deeper again, and the weeds have grown up, not quite to the surface, but waving in long branches below. The reflection of the sky is on the water at the angle at which I stand, so it takes some time before I get accustomed to the light and see into the water properly; when I do, the broad side of a big, light-coloured fish catches my eye as he sinks out of sight in the weeds. Is it my old friend? And has the recognition been mutual ? I wonder. Another mental note is made for future guidance; perhaps, later in the season, there will be a sequel to this 


\section{A\$WILTSHIRE WATER-MEADOW 69}

story. So onwards I follow the stream, stumbling through a marshy bit trodden soft by cattle, then on to sounder ground, until I reach a post-and-rail fence ending in a deep pool with a big willow hanging over it from my bank. Some one up-stream has been cutting his weeds : a pile of them lies rotting in the sun, held up by an old post near my bank. There is a gravelly shallow on the opposite side, and in it, the sight of all sights for a fly-fisher, seen for the first time in the year, a trout, taking persistently and confidently every fly that passes within a foot of his nose, following those that pass him when they come down in batches, and letting few escape. Only about a tenounce fish, but a little beauty, in good condition already, and rising freely-soon the big ones below will be doing the same! I watch him for a time, glad that I left the little rod at home. I could not have resisted trying whether I could make a fly drift through the little eddies over his nose in exactly the same way that the natural flies are drifting. Then I turn homewards down-stream. There is nothing moving in the water above the copse but one small jack, which makes a characteristic sudden dart for a few yards and then settles close to the bottom across the current. They often do 
that-I wonder how they manage it, when other fish are obliged to keep their heads up-stream.

On my way up I had noticed another big and very dark trout, lying in mid-stream about half-way down the copse. I want to study his condition, so, when about ten yards from the spot, I negotiate the muddy path on hands and knees, screened by the dock-leaves. This part of the river is like an aquarium: trees keep the glare of the sky off the top of the water, and you can see every spot on the sides of the trout, every undulation of their tails, and every wave of their fins to keep them balanced in the current. I soon spot him again, showing up nearly black against the bit of clear gravel at the tail of the weed-bed. $\mathrm{He}$ is in better condition than I thought he was, and he should improve in a few weeks; an old fish, and high time that he came out. I make once again a mental note, and stay for a few minutes watching his graceful movements as he swings leisurely from side to side to take something under water that is being swept off the big weed-bed above. Then, just as I make up my mind to leave, there appears, a few inches ahead of the trout, and about a foot deeper in the water, a dimly outlined form, almost indistinguishable from the gravel background. 


\section{A WILTSHIRE WATER-MEADOW 71}

Its outline in places is broken by brownish splotches, merging in the shadows of the gravel stones and exactly coinciding with themthe true secret of camouflage, as known to the tiger and the zebra. It is quite still, near the bottom. It looks like a long, lanky pike, but it takes me several minutes to make up my mind that it really is one. Then I remember the wire in my pocket, creep away from the water, and fetch a long withy-pole from the mill. It does not take long to attach a wire noose to the end, and then the excitement begins. One thing is certain-directly the pole is shown the trout will be off up-stream, probably into the weed-bed, and it is ten to one that he disturbs the pike. That is exactly what happens, but luckily the pike makes only a short dart and remains clear of the weeds, so that it is still just possible to slip the noose over him, taking care that it does not touch his back, sides or belly; not an easy business, because refraction makes it difficult to judge his true position, and he lies rather deep in the water for such an operation. I leave him for some minutes to settle down, and he plays into my hands by rising a little nearer to the surface. He pays no attention to the pole or wire. I lower the noose gently into the water, move it slowly 
along his body, fearing every moment that the wire may touch the tip of a fin and send him shooting off. Then I give a sudden rapid sideways pull on the pole, feel his struggling weight in the noose, and haul him hand over hand quickly to the side and up the bank amongst the dock-leaves, falling backwards myself into a bed of nettles-the wire having parted from the tip of the pole just as I got him well on to the bank! I must have left a kink in it.

I have never known such poisonous nettles as we grow in these parts. It is a merciful decree of nature that causes dock-leaves to grow so near to them! 


\section{VI}

\section{THE FIRST DRY-FLY DAY}

THE first dry-fly day! Freedom to ramble 1 in the valley of a South of England chalkstream in the month of May. A valley shut in by down-lands, its sides clothed with copses of beech-trees ringing with the song of birds. Water-meadows blazing with colour and the crystal waters of the stream itself meandering through them. Freedom to fish with the dryfly for trout from some of those meadows! The country-side at its very best, and the climax of a fisherman's expectation during a long winter in these parts at last arriving. A good hatch of fly seen yesterday, and every prospect of another to-day.

I am just back from my first dry-fly day, tired out but happy. The Chancellor of the Exchequer can do his worst and I shall bear him no ill-will. I have the luck to know the tenant of the mill, with fishing rights on both banks for about four hundred yards of copse and meadow. He lets me go there whenever 
I like, and me alone. He wires the pike himself, works his will upon the eels by every method of barbarism known to him, and leaves the trout to me. I have been watching his water for weeks, and I marked down five good trout therein. This evening there are three left. But I am going ahead too fast. I could not help it. Two beauties are lying in state on a big dish in the hall, to be admired by passers-by, and I cannot resist sitting down to share the joy of their capture with my brethren of the dry-fly who are pining in cities and longing to be where every sensible man should be when the thorn-trees are white with blossom-by the banks of a river.

To-day's captures are small-headed, deep in girth, and still keeping the golden and silver shimmer on their sides that they had when first out of the water, kicking in the fresh meadow grass. The reason of their beauty enduring so long is a special secret, not known to all troutfishers-the secret of wrapping them up in newspaper directly after they are caught. Those who do not know of this, I recommend to try the experiment. But I have got too far ahead again with my story. The first trout of the season was the smaller of the two. He was rising confidently near my bank as I walked 


\section{THE FIRST DRY-FLY DAY}

up through the copse above the mill. An impossible cast. Bushes all round me, the stream too deep, the bottom too muddy to wade in, and a strong wind blowing straight in my face. A patch of clear bank lay on the opposite side, so the best chance was to walk all the way down to the mill and up the other bank. He was still coming up to fly when I got up to him; a final touch of oil on the fly -a small "variant" with gold body-and then the first cast of the year over a fish, always a doubtful moment; but the wind helped: the fly dropped softly a yard above him, floated beautifully exactly over his nose, was sucked in, and in a few minutes he was in the net, a nice lively fish, a few ounces over a pound. Then back to the mill again to cross, because the stream bends sharply higher up and is fringed on my bank with trees, an open meadow on the other side. That meadow was the scene of to-day's great battle.

Walking cautiously up the bank beyond the copse, there was no sign of fish-life for about two hundred yards, though there was plenty of fly. A few big flies, sailing majestically amongst the lesser sorts, were fluttering on the surface or struggling to leave it. And then-a dimple, a few yards below a weed-bed, just where, a week ago, I had marked down a big trout. I 


\section{MOSTLY ABOUT TROUT}

creep up to within a few yards of the spot, spread a mackintosh on a fairly dry little hummock, recline thereon, and light a pipe, awaiting further developments. Nothing happens for five minutes, which seem like an hour; then another dimple, followed a few seconds later by another in the same place. I measure the distance by a cast well to one side, and then try for him. An eddy of wind takes the fine gut round in a loop, luckily well below him. Then a lucky cast above him and a foot to one side, the stream taking the fly in the right direction. He has it! At least, that was the obvious deduction, but all I knew was that there was a terrific strain on the line. The water is deep here-four or five feet-and the trout bores down to the bottom and stays there. I keep below him, putting on all the strain that I dare. He keeps on a steady course down-stream, with occasional turns up-stream, tearing line off the reel, which I take care not to touch, thinking of the fine gut point, until I can recover the line inch by inch. Twice he makes for a hole under a tree root on the opposite bank, a spot that I know well, probably his home when not feeding, and I haul at him as strongly as I dare and get him away from danger to my gut. The water is slightly coloured by 
weed-cutting above, and it seems as if I should never get a view of him. At last, keeping up the strain, I see a broad tail waving, and beyond it a dimly outlined form boring downwards almost vertically. He bores out of sight again and I seem to be powerless; no amount of strain will get his head up. We are near the copse, where I can no longer follow along the bank, and I look forward to a break or to a cold bath in the mill-pool; but a tremendous strain, doubling up the rod, the gut near breakingpoint, brings him just in time into slack water near my bank, where there is a shallow pool of overflow water. This exhausts him-at last. I estimate the time at between ten minutes and a quarter of an hour till he rolls over, the landing-net under him, and is lifted out. The fly was fast in his back fin! The strain had caused it to draw about half an inch, leaving a tear behind it, and it dropped free as I took the fish out of the net. He pulled the indicator on the spring balance well below the two-pound mark-a lovely fish, in the best of condition. There is always something new about dry-fly angling; never before, in fishing experience covering half a century, had I foul-hooked a trout by the back fin. Let me commend the experience to those seeking an exciting and prolonged adventure. 


\section{VII}

\section{ON THE ITCHEN, IN MAY}

A $\mathbf{N}$ undefinable charm of peace moves upon A the face of running waters. For most natures there is always something soothing in their flow; for some there is added a keen interest in the living creatures beneath. The wet-fly fisher must use his qualities of imagination and deduction about the whereabouts of fish, their moods, their fancies, and what is likely to attract them; it may be-where salmon are concerned-to annoy them. The dry-fly man depends more upon his eyesight for all this information.

In sport, as in warfare, much of the art of success lies in trying to project your mind into your opponent's brain, to look at your problem from his point of view, to study his nature so as actually to $b e$ him for the time, as far as in you lies, in order the better to understand his outlook upon the problem of the moment. To do this you must imagine your- 


\section{A DAY ON THE ITGHEN}

self in his actual environment, a difficult task at all times, even when he is a human being whose upbringing as a soldier or a seaman has followed much the same lines as your own. You may have met him. A précis of his biography may lie before you, and doubtless, if you are wise, you have tried to master his national characteristics in the pages of history or diplomacy. An even more difficult task lies before you when your opponent is not a human being but a trout, living in another element, with all the difference in the world between its optical phenomena and those obtaining in the atmosphere in which you live. Dr. Ward, by his experiments in under-water photography, has done good service to fly-fishers, both wet and dry. His photographs teach the wet-fly man the importance of paying attention to the direction of the source of light which illuminates the fly as it approaches the fish, the "flash," as he calls it. For the dry-fly man he has done more. He has shown the limits, in still water, of what he calls the "window" on the surface, through which a trout sees objects in the air above the stream or its banks. He has proved that, beyond the "window," the underside of the water-surface appears to the trout as a looking-glass, which 
reflects objects deep in the water or at the bottom of the stream and screens from sight everything in the air above. He gives us much to ponder over. He explains the optical environment of creatures in the water-world. They see upwards into the air only through a sort of inverted cone with its base on the surface of the water. Beyond the base of the cone comes the "looking-glass," in which objects beneath the water show upside-down reflections, like the mirage of the desert, above their true images. Until a dry-fly floats into the window, or base of the cone, the trout can see only the submerged portion, the hackle and perhaps the body and the hook, projecting through the surface of the lookingglass. When the fly comes into the window the whole of it appears, in silhouette, against the sky.

I have often wondered why a certain artificial fly, which resembles no insect of my acquaintance, should do as well as it does in dry-fly water. Trout sometimes move quite a long distance to take it. It is dressed with a very long, bristling hackle, which holds it well out of the water, and wings pointed forward, with either a quill or gold tinsel body. The friend who earned my everlasting gratitude by teach- 


\section{A DAY ON THE ITGHEN 81}

ing me to fish dry-fly calls it "M. Pegoud," after the pioneer of human inverted flight, because it generally alights upon the water on its back, hook upwards. Obviously the hook must therefore be unseen by the trout, while the fly is in the "looking-glass," showing only the hackle; perhaps that is why the fly does so well. We can ponder over that and other problems while, like good dry-fly water, we glide slowly on our course towards a dryfly day.

The man who fishes dry, as we have noticed, has more direct evidence than the wet-fly man about the whereabouts of his opponent. $\mathrm{He}$ locates every individual trout. Either he sees them in the water, or he sees indications of their presence, breakings of the surface, which may or may not be true rises to floating flies. Whatever they are, they show the actual position of the trout, and then- But it is hopeless trying to describe such moments : the instant alertness, perhaps after a long wait, the thrill of excitement, the enforced calmness of brain while thinking out the problem of approach unseen to casting distance, how and where to cast, what fly-but we will leave that aspect of dry-fly fishing for the present, and words are a poor medium to convey such feelings. 


\section{MOSTLY ABOUT TROUT}

When the trout himself is visible you can, with practice, form a fair estimate of his size and make up your mind whether to try for him or not. (Even when he is not seen, the breaking of the surface gives indications.) Then his mood. What sort of mood is he in ? Hungry? confident? easily frightened? suspicious? dainty? His attitude in the water tells you much, if you can see him. You soon learn that every trout, like every man, has his own individual character, and on well-fished waters he has personal experience superimposed on hereditary instinct and caution. The character of each trout remains constant, but his moods vary. During the "morning" rise-if there is one, in these days of summer-time, when one o'clock is really noon-his mood is not the same as it will be in the late afternoon, and during the late evening rise it may again be quite different. Always, if he shows by his movements that he is taking an interest in his surroundings, it is worth while to try to tempt him. I have in mind a large trout, just over three pounds in weight, that I hooked and lost twice early in one season, and fished for intermittently on occasional evenings for three months afterwards. Sometimes he disappeared after the first cast. Sometimes he came up 


\section{A DAY ON THE ITCHEN}

perpetually, to take natural flies only, however often he saw the artificial, and however many patterns thereof were presented for his inspection. At last, at the very end of the season, he made a mistake and was landed successfully, after a tremendous struggle.

Some trout are lethargic both in character and mood. These may remain-permanently, as it seems to us who only visit the water by day-deep down in the water and quite inert, seemingly asleep. With such trout I have had no success, and after much unrewarded effort I have given up trying to take them. There is a certain tradition of backsliding from complete candour in fishing-stories which makes me hesitate before adding a true tale of one such fish who was abnormally indifferent to his surroundings, but all fly-fishermen will recognize the truth of this particular story, because, if not true, why should I place before them such damning evidence of frailty and deviation from the fly-fishers' code of morality? A certain valued friend, who was forbidden by his doctor to eat nearly all foods but fish, was coming to luncheon with us. We had no fish. I took my rod down to a small chalk-stream containing large trout, and soon spotted one, lying fairly deep in the water and quite inert, on a 
gravel patch a few feet below the end of a weedbed. I stalked him in the approved fashion from below, keeping myself and my rod out of sight. I put several flies over him without attracting his attention. I then managed, with some difficulty, to drift a sunken fly past his nose by the method described by Mr. Skues in his Minor Tactics. Each time the fly was ignored. Then I walked up the bank for a closer inspection of the fish. Much to my surprise, he allowed me to come within about three yards without paying the least attention to my movements. The morning was passing away. The fryingpan and gridiron were awaiting my return. The predatory instincts of some cave-dwelling forebear were strong within me. I threw the gut-cast over his back and recovered it swiftly; I am afraid with some subconscious idea that the hook might attach itself to his person. It did not; but the strange thing was that even then he took no notice-he did not seem to be even ticklish, much less alarmed. Then I laid the rod itself gently on the trout's back, and drew it smartly towards me to wake him up. Then at last the fish withdrew with dignity, and a gentle waving of his tail, into the fastness of weeds. Maybe that trout was blind in one eye, which would afford an explanation of his being 


\section{A DAY ON THE ITGHEN}

so conspicuous an exception to universal experience of the timidity and wariness of his kind.

We seem to have wandered a little out of our course towards a dry-fly day, but that is one of the advantages of the art: there is usually no hurry. However long you may linger over breakfast, you generally arrive at the water too early; and then, again, the joys of anticipation are not to be despised. Lord Grey of Fallodon confessed lately that during his public career he was obliged to ration himself in the pleasures of anticipation, and never allowed himself to dwell at night upon thoughts of the approaching fishing season until after the 1st of January, for fear that his work should suffer. Here is an extract from the address which he delivered not long ago in the United States, which is worth reading before our dry-fly day begins :

You can get greatness, too, from . . . a keen sense of the beauty of the world and a love for it. I found it so during the war. Our feelings were indeed roused by the heroism of our people, but they were also depressed by the suffering. In England every village was stricken, there was grief in almost every house. The thought of the suffering, the anxiety for the future, destroyed all pleasure. It came even between one's self and the page of the book one tried to read. In those dark days I found some support 
in the steady progress, unchanged, of the beauty of the seasons. Every year, as spring came back unfailing and unfaltering, the leaves came out with the same tender green, the birds sang, the flowers came up and opened, and I felt that a great power of Nature for beauty was not affected by the war. It was like a great sanctuary into which we could go and find refuge for the time even from the greatest trouble in the world. . . .

The continuance of the beauties of Nature was a manifestation of something great and splendid which not all the crimes and follies and misfortunes of mankind can abolish or destroy.I

I will not make any inadequate comments. We see a picture of a great man, deeply stirred by the sufferings of humanity, seeking solace in the beauty of Nature (by running waters). It was not quite from that angle that I meant to approach our dry-fly day. Let it be in the ordinary work-a-day world, and let us take our text from the same writer's book on FlyFishing :

If work be worthy or noble, the greatest satisfaction of life is to be found in doing it well; the exercise of his highest powers is the glory of man's being, and the discovery or development of them by use transcends all pleasure. But not all work is of this kind, and in most if not in all of it there is much drudgery, so that we are tormented from time to time with a strong desire to get

× Recreation, by Viscount Grey of Fallodon. 


\section{A DAY ON THE ITCHEN}

away from it.... Most of us endeavour to divide our lives into three parts-work, rest and recreation; and it is with the management of the third part, and the place of angling with regard to it, that this is concerned.

With us lesser folk it may be that the nobility and worthiness of our work is a less conspicuous feature, but to get the utmost enjoyment out of a dry-fly day, it must be preceded by a long spell of hard labour in some town or city. Let it be in early summer, when we have been pining for country sights and smells, and only the mental alertness and human interests of the town have inspired us to suppress such longings and to "stick it out." We probably arrive at the London terminus with brain and body weary and nerves overstrained, and we doze during the journey, waking up at times and recognizing familiar scenes passed on the line. We get out of the train with all our powers reviving with the change from town to country air. We feel fit for anything. If we are wise, we realize that we are not. The fullest enjoyment of many a dry-fly day is lost by over-keenness, by attempting exertion beyond one's physical powers when out of training, and-I confess to the weakness-by failing to accept philosophically such incidents as the catching of a hook in one's clothing, or 
such crowning disasters as the loss of a big fish in the landing. We do not get the best out of existence if we rush hurriedly from work to strenuous recreation. In our younger days we are most of us inclined to do so. I certainly was, until I read and digested R. L. Stevenson's little maxim that "Extreme busy-ness is a sign of deficient vitality." Before that I had imagined it to be the sign of the opposite, but, thinking it over, we are struck with the idea that "busy" folk only wear themselves out without producing much lasting result. We get some help on this point from Charles Kingsley, another keen chalk-stream fisher, but not of the dry-fly persuasion. I suppose that most of us know our Water-Babies, and have learned from Mother Carey, as little Tom did, the great secret. As she got through so much constructive work, he thought that she must be too busy to talk to him- "I am not going to trouble myself to make things, my little dear; I sit here and make them make themselves." Kingsley, by the way, got that wisdom from the East, but to follow up the origin of the tale would be too much of a digression.

The moral for the fly-fisher, of course, is to study Nature and apply her laws to his purpose, from those affecting the waywardness of trout 


\section{A DAY ON THE ITCHEN}

to those governing the play of rod and line in throwing a small fly into the teeth of a downstream wind. The rod will do that for him, when once he gets the trick of not interfering too much with its activities, and so exhausting himself to no purpose. Skill in casting accurately and without fatigue is a great asset to the dry-fly man. Like most things worth having, it can only be acquired by hard work and constant practice. To some folk it comes more easily than to others, but when it does come it brings with it a feeling of admiration for the qualities of a good rod that can work such wonders with so little human help. Every foot of a cast, line and rod, from fly to wrist, then seems to be alive, and at the same time under perfect control. Shall we imagine that we have it, before we begin our day ? "Let's pretend" is a lovely game, both for young and old.

And now our dry-fly day is dawning. The river is quite close. We shall arrive at it fresh, without having drawn upon our reserve of energy by a long and tiring walk. We shall get plenty of exercise before sunset. Late as it was, we could not keep away from the water last night; we smoked the last pipe leaning over the low parapet of the old stone bridge near by, looking down into the glassy water at 
the waving weed-beds and the forms of the large "bridge" trout, the anglers' pets. Then we slept soundly between lavender-scented sheets, breathing country air laden with the night-scents of garden-flowers. The earlymorning twitterings, followed by the bird-chorus, reminded us of the day's holiday before us, until we lost consciousness again in a last delightful doze. Then we woke up once for all and looked out at the weather.

What weather shall we choose? Let there be promise of a hot day, but not a thundery one, and let there be none of those adhesive flies that afflict the angler in the heat-haze of the later months. Let there be a hot sun, but some freshness in the air, and let it not be too late in the season to see orange-tip butterflies flitting along the high hedgerows of the grass-bordered road. Let the wild roses be out, and foamy masses of heavy-scented elderflower. Let there be may, both white and pink, single and double, yellow laburnum and lilac; let there be some copper beeches to show up as a background thereunto. Let all the trees be in fresh foliage, not dense enough to hide the birds, and let everything have been washed clean by a recent shower. And now to the business of the day. 


\section{A DAY ON THE ITGHEN}

First, the soaking of the gut. Some folk wait until breakfast-time, and then use the slop-basin, with only hot water from the jug available to fill it. I always use my soap-dish, first removing the soap in its tray, and cold water, and I leave a gut cast and a few points to soak there during breakfast, coming up afterwards to fetch them. If we are lucky enough to live here, the rod is up already, with the reel on it, and the line threaded through the ring-an exasperating operation, it always seems to me, taking much too long when you are longing to start, especially if you find, after attaching the cast, that in your keenness to be off you have missed out a ring, and have to go through the whole operation again. Then the soaked cast goes on, a point and a fly attached; the cast is passed round the back of the reel, and the fly is then hooked into one of the rings on the rod, a touch of paraffin is put on the fly with a brush, the rod is stuck in the grass by the spear in the butt, and you pull on long waders for the water-meadows. Then you sling the fishing-bag on your shoulder, landing-net attached, pocket your luncheon and a flask (or a couple of bananas in the place thereof) and mentally muster your kit. Rod and appurtenances as already described. Little 
box of dry-flies. Spare casts and points. Paraffin bottle and brush. Something to cut with. Bit of indiarubber to straighten curly gut. Springbalance marked in pounds, ounces and fractions. A little pocket "priest" to give the coup de grâce. Pipe, tobacco and matches.

Once I saw a similar list-I cannot remember where-written out carefully by a dear old absentminded fisherman of a past generation. The last item on his list was "Kiss wife."

Then you pick up your rod with a vague feeling that, after all, you have forgotten something important. So you have. I began this article with an analogy between trout-fishing and warfare. Many years ago, after having as a subaltern had some experience of active service involving hard marching, it fell to my lot to instruct classes of young officers likely to be similarly situated. There was much to teach them, but I remember ending my course of instruction with the words "Grease your boots," and years afterwards I received many grateful thanks for that advice. For the dryfly man there is the all-important maxim " Grease your line." You cannot do so too often, and for two reasons. A well-greased line lies lightly on the water, keeping rod and fly in intimate touch with each other, and a floating line is more 


\section{A DAY ON THE ITGHEN}

easily picked off the water than one sodden and waterlogged. A good recovery of the line is more than half the battle in casting. So before starting, and again during the day, as much of the line as will lie on the water must be well greased. Deer-fat is good, spread on chamois leather. So is an equal mixture of vaseline and candle-wax, boiled together and then cooled into a little cake.

Now we can really start upon our way. The place that occurs to me for the moment as the best to wait for the rise is on the Itchen, the finest dry-fly river in England. ${ }^{x}$ A nice shady spot to wait, as the river there runs through a wood with high trees over the water, no low boughs to interfere with casting, and a pathway to follow, close to the river, on the right bank. The shaded light enables you to see every spot on every trout within range, and the trees prevent you and your rod from showing against the sky. We will begin fishing as soon as a hatch of flies come floating by and the trout begin to take them. Meanwhile, we can observe their habits and learn much about the crosscurrents in the water: we notice some trout heading up-stream; some few, in deep places,

I Above Winchester, perhaps; below, the road-tarring has practically ruined the fishing. 


\section{MOSTLY ABOUT TROUT}

lying across, showing which way the undercurrents set. Above the wood is a wide bit, with a long cast to the other side, where the trout lie; then a plank bridge takes us over to the left bank and a lovely bit of dry-fly water, where you see the rises but not the trout. There, on a few hundred yards, we can spend a happy day amongst trout that, if we select the most sedate-looking rises, should average about a pound and a half, or rather more. How many shall we allow ourselves? Three brace, weighing nine pounds, during the day rise, should be enough to satisfy anybody, especially if there is a two-pounder amongst them, with the chance of another brace in the evening. The hooking and landing of such trout has been described by many pens. The spotting of the rise, the selection of the spot on the water where the fly should drop so as to float light-heartedly over the fish, following the eddies of the stream without being affected by the drag of the line lying on the water down-stream; the flicking of the fly to dry it well, and the final cast, the tense moment as the fly passes exactly over where we saw the rise, the gentle disappearance of the fly as a big trout takes it, the steady lift of the rod as he closes his mouth and turns downwards, the tremendous feeling of elation 


\section{A DAY ON THE ITGHEN}

as the rod-top bends and the butt and wrist throb with the strain, the playing of the fish; wondering whether enough care was taken in attaching the fine point to the cast of gut, the final tiring of the fish, until-we hope-he is guided by the strain down-stream steadily into the net, carefully lowered near the bank to receive him, and, at last, the lift of the net, heavy with his weight. If that has happened six times in a day, with disasters galore intervening to accentuate each triumph, such happenings should suffice for deep contentment. It is strenuous work; the fisher does justice to his tea on a summer's afternoon, and, if he is wise, he adds two poached eggs thereto before tackling the jam and cake, and he has the loaf on the table, if he means to go out for the evening rise. That will be better later in the year, when that delightful feeling of freshness comes into the air after a sweltering hot day, and the valley is bathed in the yellow afterglow of the sunset.

And to all dwellers in towns, with the joys of fishing latent in their souls, I would say, with Izaak Walton :

But turn out of the way a little . . . towards yon honeysuckle hedge; there we'll sit and sing, whilst this shower falls so gently upon the teeming earth, and gives yet a 
sweeter smell to the lovely flowers that adorn these verdant meadows.

Look! under that beech-tree I sat down, when I was last this way a-fishing. And the birds in the adjoining grove seemed to live in a hollow tree, near to the brow of that primrose hill. There I sat viewing the silver streams glide gently towards their centre, the tempestuous sea; yet sometimes opposed by rugged roots and pebble-stones, which broke their waves and turned them into foam....

As thus I sat, these and other sights had so fully possessed my soul with content, that I thought, as the poet has happily expressed it,

I was for that time lifted above earth And possess'd joys not promised at my birth.

But every wise man has his own hobby, and to those to whom such joys do not appeal there remains the advice of the statesman from whose address, delivered in the United States at the Harvard Union, in December 1919, I have already quoted: "If you do not care for fishing, do not fish. Why should you? But if we are to be quits, and you are to be on the same happy level as I have been, then find something for yourself which you like as much as I like fishing." . 


\section{VIII}

\section{A WEEK-END IN WILTSHIRE}

T SUPPOSE that there were week-ends in 1 war-time; but then no one could abandon himself fully to the joys of the country. Even over the banks of a Wiltshire troutstream there always hung the war-cloud, and thoughts of the thin and ever thinner line of the best of our manhood, bending and nearly breaking before the pressure of enemy hordes driven forward to destroy all the ideals that make life worth living in this world. Now all is changed. This is the story of a typical May week-end in Wiltshire water-meadows.

After the usual journey from Waterloo through the wilderness of brick that seems' never-ending, till sleep comes to one's aid, eyes open upon a country of dry-looking downs which might be in the Free State or the Transvaal, if it were not for the happy knowledge of a little trout-stream and its water-meadows, tucked away only a few hundred yards from the part of the line 
we are now passing over. Let us get on to the next morning as quickly as we can, to a little earthly paradise already described, where, alas! there is only room for one, who carries the knowledge of it about as a happy secret throughout the whole working year. There are only two water-meadows, and a copse, on the right bank of the stream; a wood and two copses extend along nearly the whole length of the other bank, and under the boughs of them I know of several heavy trout. It is a wee river, best fished with a little eight-foot rod, a typical chalk-stream, with water as clear as crystal except for the little gentle swirls on the surface where something beneath obstructs the free run of the current. Gut must be of the finest, or every trout that sees it will flee to cover. The rod is ready, put up overnight and picked up in the morning in a little study fragrant with the scent of lilac and pheasant-eyed narcissus. Out into the garden by widely opened French windows, down a hill, and away by a dusty road to the gate leading into the water-meadows. Splash through sparkling little runnels of clear water in the rich emerald-green grass, dotted with golden clumps of marshmarigold; one of my waders sticks in a mudhole in my hurry, as the moment gets nearer 
for my first view of the chalk-stream. Down on my hands and knees for the last few yards, for fear of scaring a big fish whose usual haunts I know; just a moment's pause, to touch the hackles of the little fly with oil, in case he should be rising, and then-I raise my head slowly and cautiously to look at the water-the stream is coming down as thick as pea-soup. The people above are cutting their weeds, which are passing by in great masses, and they are sending down all the mud that has accumulated in their mill-pool during the past winter. Numbers of flies are floating on the surface of the pea-soup, which would mean a good rise and a splendid day, if the trout could only see them.

There is a certain missionary hymn, familiar to us all in our early years, about a country where prospects please but the vileness of man is accentuated. I decide to concentrate upon the pleasure, ignore the vileness, and spend my remaining two hours (there is work to be done in the afternoon) watching the pea-soup flow by and listening to the bird-chorus. The cuckoo soon becomes a burden, as the whole air seems to be full of his note ; the blackbirds and thrushes are silent for the time, but a nut-hatch is busy in the wood opposite with his queer noise, and there is a snipe drumming somewhere overhead. 


\section{MOSTLY ABOUT TROUT}

As I go up the bank I scare a wild duck. She goes down-stream, pretending to have a broken wing in order to lure my attention away from her seven little ducklings. A moorhen with her queer little black fluff-ball progeny runs over a weed island, and water-rats swim from side to side of the stream or dodge along the banks.

Near the bridge, my top boundary, I find a big New Zealander and a pretty, fresh-looking country girl. Where the stream laps the roadedge are two little rival fishermen, luring minnows into bottles with bread-crumb bait. Time passes in talk. I look at my watchonly ten minutes more. The water seems suddenly to be clearing. Soon I see the weeds at the bottom, then-a dimple on the surface, under the opposite bank. It seems almost too good to be true. There it is again! and this time an unmistakable rise to a small fly, swirling out from under the bridge arch. There he is, up again. The New Zealander, coming as he does from a land of trout and knowing their shyness, melts away out of sight, taking his companion with him. I sink down on my knees in the mud. Two flicks in the air to dry my fly, a cast to one side to measure the distance, and then a cast over him. He won't have it. 


\section{A WEEK-END IN WILTSHIRE IOI}

I put it over him again, twice, and then try another fly. No result. $\mathrm{He}$ is still rising. Another change of fly. No result. Then a rest for thought. He is rising more confidently, and the idea enters into my mind to try the first fly again. He takes it, firmly hooked, and there is a terrific strain on the line. I am below him, but seem powerless to turn his head downstream. A rapid rush towards the bridge. He changes his mind and rushes down-stream at me. A splashing, stumbling sprint along a muddy bank to keep the line taut-a cautious reeling-in -a gentle guidance down-stream between weedbeds and under boughs of trees until he comes under my bank. An attempt to guide him into the net placed below him, and-the first sight of it sends him ten yards up-stream again. Then a steady strain till he is in a narrow channel where the net awaits him in a runnel between bank and weed-bed. Most of him seems to have headed into the net. A strong, firm lift-he is in it, and I stagger away from the stream into the meadow, with knees shaky, relaxed muscles and a queer feeling of exhaustion. One knock on the head from a pocket "priest" -the fly had come out of his mouth as he entered the net! A trout in prime condition, deep in outline, gleaming golden in the sunshine, and 
102 MOSTLY ABOUT TROUT

his weight by pocket-scale $3 \mathrm{lb}$. $4 \mathrm{oz}$. For the sake of brother-fishermen I will add that the rod was a little one, the gut point an Ogden Smith's twenty-inch fine "four $x$," and the fly of size 00, a "variant"; but to no fisherman can I dare disclose the exact whereabouts of that little paradise where I spend my week-ends in Wiltshire. 


\section{IX}

\section{A MAY-FLY DAY}

TT seems only a day or two-it is really 1 many weeks-since I was splashing along the banks of this stream one bitterly cold day, searching for pike, and the first swallow appeared as a promise of what was to come. Then, suddenly, came the spring, and the gorgeous marsh-marigolds and delicate lady's-smock showed in the rich water-meadow grass. There were primroses and wood-anemones in the withybeds. Now summer has come; the grass has sprung up nearly a foot in the warm sunshine, and it is filled with wild flowers innumerable, of names known and unknown to me. The whole valley is resounding with the monotonous note of the cuckoo, and the air is filled with the song of birds; the sound of bells just reaches me from an ancient church-tower in the distance. It has been a wonderful day's fishing in these crystal waters, which now flow slowly in the long stretches, faster in the runnels between 


\section{MOSTLY ABOUT TROUT}

the flowering weeds which in places obstruct the channel. Trout love the shelter of those weedbeds in the daytime. Neighbours have paid no attention to their wants, and have shaved off closely all the luxuriant water-plants; the result has been that every big fish for miles has fled to these two meadows, and the average weight of those I have caught this year is the greatest I have ever known-2 lb. 10 oz., all deep fish in prime condition. To-day I have landed three of these monsters and two others have escaped, the fly having come away after holding only for a few seconds.

It has been a glorious day, with everything for once in favour of the fisherman, including a gentle air up-stream to take out the last twentyinch link of the finest gut and the tiny fly. There was a long wait before the trout began to show themselves. It is impossible for a keen fisherman to remember that our new idea of keeping "summer-time" has not yet spread to the water-world, so, of course, I went to the meadows much too early; but. with everything freshly coming out and no signs of decay anywhere, there are plenty of compensations for an hour or two's idleness in water-meadows in May or June. I will not enlarge upon them. There are those who jeer at the dry-fly fisher because 
of the attention he pays to things apart from the catching of trout. I will not invite their criticism; I share their views of the influence of a heavy basket upon the enjoyment of a day's fishing, and my three fish, weighing nearly nine pounds, bring a comforting strain upon my right shoulder. The May-fly rise began in the late afternoon, and two of my three captives were taken during that time, but not with Mayfly. Far be it from me to speak slightingly of the "duffer's paradise." As I fish this stream with so small a rod, I do not like a great flapping May-fly at the end of a fine cast, for the simple reason that I cannot manage it properly. I love the little flick behind me of a tiny dry-fly, because I know that, when it does that, it will go forward accurately and alight with wings cocked, within a few inches of where I want to place it. A May-fly does not flick, it flaps. The fish I have so far hooked have all taken a small fly of the size that is called by the tackle-makers " 00 "; and now I come to the last chance of seeing a rising fish on my way home.

I am passing through a little wood where a mill-pool is overhung with trees. The sluices have been opened for some days to let the procession of weeds, cut in the higher reaches, pass 
away down-stream. The result is that the water is very shallow here, and very clear. You can see every living thing in the pool, and on my way up-stream earlier in the day I marked down in it two large trout, light in colour, in good condition, and weighing, I should say, about three and two and a half pounds respectively; but both are those nerve-shaking enemies of the dry-fly fisher, "cruisers." They refuse to conform to the practice of all large trout of normal habits; they do not select the best spot for feeding, and remain there, leisurely sucking in the flies that pass exactly over their noses, refusing to move more than a few inches to right or left in pursuit of other passing food. To take such normal trout is a comparatively easy task; at all events you know the rules, even if you are not skilful enough to follow them. You must so arrange that your fly floats, with its wings cocked, directly over their noses ; there must be no "drag," the fly must not be pulled by the line, but be floated along like a natural fly, resting on the stream as if there were no line attached to it; and you must not let the trout see the line itself, only the last link of your cast, which is of the finest gut. Above all, the fish must not see you or your rod. If a trout conforms to the rules, keeping his 


\section{A MAY-FLY DAY}

head always pointed in the same direction, upstream, you know where you are, and keep out of sight by being well below him. "Cruisers" obey no such rules; they take a few flies in one spot, and then leave it for a cruise, either up or down stream. Generally, they cruise about on a course forming roughly an oval, but you cannot be sure that they will do so. After that preface, let us get to business.

As I pass down a path in the wood, overgrown with huge dock-leaves and nettles, I see the larger of my two friends of this morning rising steadily in about eight inches of water on the other side of the shallow mill-pool. Down amongst the dock-leaves at once, lest he should see me, and into the water close under the bank, between two trees growing most awkwardly for casting from my side of the stream. A cold sensation, as the water wells in through a hole that must have been made in one of my waders by a sharp nail in a fence I crossed lately; but such trifles must not count; it is my only chance. If I hook the fish I cannot follow him along the bank because of the trees, and I know that when not foraging for surface food his home is in a certain deep hole about twenty yards down-stream. All I hope for is that I shall not sink up to the waist in the soft mud collected 


\section{- 108 MOSTLY ABOUT TROUT}

under the bank. He is still rising, and I am just getting my rod up for a cast when he starts for a cruise, heading down-stream directly for me. I keep perfectly still; my heart in my mouth. About level with me, he turns up-stream again, taking an occasional fly as he goes, and making only the least dimple on the surface as he does so. He was so near to me at one time that I saw every spot on his side, but the background of bank and trees just saved me from discovery. He gets back to his old place and feeds there again; now for the first cast. The boughs of the tree below me do not come down to the water-the lowest is fortunately about six feet above the surface of the stream; I can flick the fly under it for the back cast, and so get it forward to where the fish lies. Five minutes of underhand casting, trying to get the fly above the fish, failing every time, and then he is off for another cruise. This time he goes a few yards up-stream and then comes down the middle, again without seeing me. He goes back to his old place. I move up two yards, and in doing so get one foot stuck in the mud, making a wave as I pull it out. The wave goes over him, and he stops feeding for what is probably a minute, but it seems like an hour, pondering over the phenomenon. Then he takes 


\section{A MAY-FLY DAY 109 .}

a fly again; a little puff of wind helps me; I can reach him now, and I get my fly over him several times. He will have none of it, though he turns up to it twice, and once follows it for two yards down-stream, examining it with interest till it drags, pulled by the stream sweeping down my line, which floats on its surface. (I have not dared to lift the fly while he watched it, and if I wanted to I could not, as boughs of the tree are just above my head.)

Then an awful moment of suspense. I hear someone coming down my bank, and that someone, if seen by the fish, will put him down for good. By great good fortune it is no stranger, but Herself, come out to find out at what time I am likely to be home for supper; and Herself, knowing the ways of trout, drops upon her knees in the muddy path between the dockleaves as she catches a glimpse of my hat showing above the bank. And then comes great luck. $\mathrm{He}$ is taking May-fly now, and taking them confidently, so a May-fly he shall have, in its "spent-gnat" form, which is generally, in my experience, the most attractive. The usual horrid flap at the back end of the cast, and the fly falls about two feet short. Four times I fail to reach him, and then he moves up about a foot. One more try, and this time a gentle 
up-stream air helps out the last link. The fly alights gently, a foot above his nose. $\mathrm{He}$ takes it confidently, and, as soon as he feels the hook, dashes full-speed down-stream to his haunts below. I cannot raise my rod to play him at this spot, so have to put the strain on sideways when he stops his rush. The struggle, splashing down to him, reeling in as I go, waders sticking at every step, the clear stream becoming thick below me with the mud thereby stirred up, and, after a five-minutes' battle, the final lift of the landing-net, into which he has blundered in the thick water : all this I leave to the imagination of brother-fishers. Then I clamber up the bank, splashed from head to foot, and with hands and face stung by nettles as I get up the steep side. I had overestimated his weight by only two ounces. His good condition I had not misjudged, as he showed by a tremendous fight for freedom.

Herself and I walk homewards together. The whole course of the stream is marked with clouds of May-flies rising upwards from the water, and the clouds turn a delicate pink as the glow of the sunset sky shines through myriads of transparent wings. We seem to hear a gentle rustle as the flies rise in thousands from the stream and flutter upwards into the new element, 
of which their water-life could have given them no conception. Mrs. Gatty's parable about the Dragon-fly, who, to some of his brother-watercreatures in the pond, was " not lost but gone before," comes back from the memories of childhood. But I am wandering with the May-flies into regions celestial. Dry-fly fishers must not digress from their business, the catching of fish. We went home to supper. There was a trout, with flesh rosy and firm. There was also salad, gooseberry-tart, and cider from a cool cellar. Brethren of the Dry-fly, I bid you Good-night, and may your dreams be as pleasant as my waking hours on a May-fly day. 


\section{$\mathbf{X}$}

\section{AN EVENING RISE}

T $T$ has been a stiflingly hot day in the 1 Itchen Valley. The cold north-east winds of May that sometimes try one's skill to the utmost in up-stream casting seem to be very far away in a long-distant past. The glory of June has gone by, with its well-defined day-rise, when trout were easy to take. On this July day of scorching heat, fishing has been very difficult and very strenuous. Not a rise has showed on the surface. One or two little trout have leapt out of the water, always a bad sign for fishermen. It has been a case of hard and continuous work in a hot sun, plodding about in heavy waders through deep mud and occasionally peering through the sedges on the chance of seeing a good trout looking sufficiently alert for it to be worth while to drop down-stream and cast for him. Not one sizeable fish would look at anything but the smallest fly, and a red quill on a " 000 " hook, 
attached to a long point of fine (xxxx) gut, with not a knot showing thereon for eighteen inches. In six hours' fishing three such trout were induced to take. They usually average almost exactly $1 \frac{1}{2} \mathrm{lb}$. in weight in this particular bit of the Itchen (between the Tichborne and the Avington Park water). One of the three, from the feel of him and the dignity of his movements, I should say must have been $1 \frac{3}{4} \mathrm{lb}$. or over. All three got away, the tiny hook having lost its hold. A day of disappointments and of sheer toil, begun in over-keenness, and ending, for a time, in physical exhaustion. There was one compensation, companionship of the best, that of a fine soldier, late of the Rifle Brigade, whom many would place at the very top amongst those who put the soul into the little old British Army of 1914.I Of him it was written, after the country had lost him: "He banished all meanness from his neighbourhood, all thoughts of self-interest and personal advancement. Duty, discipline, self-discipline, and the joy of life -these were the rules he walked by; and if you found yourself in his company you had perforce to walk with him, keeping up with his stride as best you could." " We had been

$x$ Brigadier-General J. E. Gough, V.C., C.B., C.M.G., A.D.C.

2 Ordeal by Battle, F. S. Oliver. 


\section{MOSTLY ABOUT TROUT}

together for part of the day, and we had met for luncheon at the big hatch by the lower boundary. A curious incident happened there. We were both too keen to take our eyes off the water for long, in case the luck should change, and, while we were having our luncheon, we saw a lively-looking trout, less than a pound in weight, suddenly begin to rise confidently at something small which we could not distinguish. He was within easy casting distance, and we put fly after fly over him without sending him down, also without any sign of interest on his part. At last, by way of experiment, we tried an enormous silver sedge, tied on a hook of about 3 or 4 . He seized it at once! There is no accounting for the ways of trout. Like women-folk, they are creatures of "infinite variety."

By three o'clock things had got beyond a joke. The air seemed all used up and enervating; such trout as we could see were all on the bottom, rigid, and apparently asleep. Flies swarmed round our faces and wrists; flies that settle again within a few seconds, however many times you brush them off, and leave a sense of clammy stickiness wherever they have settled. Fishing seemed more hopeless than ever. We gave it up. We rested in 


\section{AN EVENING RISE}

the shade as far as the flies would permit, taking turns to visit the river occasionally, in case any trout should have begun to feed. We had tea, boiling our eggs over a little fire of dry wood and taking refuge from the flies in the fragrant smoke. So the long afternoon passed away....

Suddenly there came a subtle change in the air. Shadows were beginning to lengthen, and the sunlight began to tinge the landscape with gold. It was time to try again. Waders and the thick woollen stockings that go therewith had been lying spread out to dry in the sunshine while we luxuriated barefoot in the warm, sweet grass. Tackle had been overhauled and line greased afresh, to ensure its floating well during the evening rise. Soon we had donned wading equipment, slung fishingbag and landing-net over the shoulder by the strap, of which it is such a joy to be relieved for a time in hot weather, and we returned to the water as keen as ever. By no means too soon: the trout were already on the move; they were beginning to take up positions for a good view of the moving supper-table soon to pass between them and the sky. Here and there, at long intervals, one rose. If the moods of trout change from month to month and 


\section{MOSTLY ABOUT TROUT}

from day to day, how much more do they change from hour to hour of a long, hot summer's day!

Sometimes, early in the day, you find a good fish poised a foot or so below the surface, not actually taking fly, because at the moment there are none to take, but evidently on the look out and paying close attention to his surroundings. You manage, by skill or by sheer good luck, to get a fly over him nicely, without showing him too much of the gut. He takes, confidently-if you let him. Sometimes, if he turns towards you, following the fly a few inches down-stream, and you get a view of the pink interior of his great mouth, the temptation to tauten the line too soon (and thereby lose all hope of hooking him) is irresistible. If you do that you may possibly prick him; you are certain to send him off to his favourite weed-bed or hole under the bank to ponder for the remainder of the day over the deceptiveness of appearances. Sometimes you give him time to shut his mouth, and, if you do, he takes confidently. You want quick eyesight and the trick of getting the light at the right angle, to spot the non-rising fish which are likely so to take. I have known great days of sport and heavy baskets on hot, still days, in baking 


\section{AN EVENING RISE}

sunshine which makes the gut glitter, as seen from your point of view, and therefore, be it noted, not from the point of view of the trout, who sees things from a different angle and against a different background. During such a day, if you can face the hard work in a hot sun and wander about constantly, keeping yourself out of sight and not shaking the bank, or making a wave in the water, should you be wading, it always seems to me that the confidence and unwariness of trout are at times amazing.

The same fish have changed in their character completely when they come up between six and eight in the evening to make surface rises. They seem to be confident and unsophisticated. Whatever natural food they may be taking they do not seem to be investigating closely, but just to be sucking it in gently, making a little ring on the current. Try them with the artificial. The least glimpse of the gut, the smallest error in the cock of the fly, and they are scared at once. They bolt for shelter, sometimes making it their business to dash about and alarm their neighbours within a range of many yards. Whether I thereby eliminate the faulty cock of the wings of the fly, or for some other reason, I generally find 


\section{MOSTLY ABOUT TROUT}

a small dark fly, tied with soft short, bristly hackles and no wings, the most effective with such trout.

On that summer's evening on the Itchen of which I write, we had good fortune with those early evening rises, and we had grand sport, an unusual experience in the slanting sunrays. You generally have to wait for success until they are off the water. Then came the great moment, when the sun had dipped well behind the chalk-hill downs, when great noses came up to make head and tail rises, showing dark upon the waters, gleaming golden and rosecolour in the afterglow. Such an end to a long day of disappointment! They were taking little flat-winged spinners confidently. The evening rise not only looked good, as it so often and so deceptively does, but it was good. They really took, and shut their mouths tight upon the fly, so that when the rod point was raised the little hook was firmly embedded, every time in something firm and holding. When one rod was waiting for the next rise to show, the other was often bending and throbbing; the music of the reel, the finest music of all to a fisherman's ear, was wafted across the meadow on the evening air as an encouragement to further effort. My pipe, to complete the 


\section{AN EVENING RISE}

picture, was drawing well, and the curl of smoke therefrom kept the midges from assaulting that most vulnerable spot just where the forehead meets the lining of the hat. Even then the sport was not over. As darkness approached sport got even better and fish bigger. In time, it was no longer possible for the keenest eyes to spot the floating fly, though in places, where the reflection of the sky struck the water, even a small one could be seen for a time. Large sedge-flies and moths then came fluttering along the banks, and the last and heaviest fish was taken on a silver sedge, after many minutes had been wasted in trying to attach the gut thereto. In my excitement I had forgotten the old trick of looking upwards against the sky at the eye of the hook, so as to see it more clearly. The fast-fading light makes every minute precious, and the feeling that it is so tends to rattle an over-eager temperament.

That evening rise leaves lingering memories not easily effaced. The cawing of the rooks in a distant rookery, the bicycle ride to the inn at Itchen Abbas, a well-known fisherman's resort, along the dusty road between dark hedges and overhanging trees. Past gardens with rambler-roses, flowers and sweet herbs giving out their scent in response to the cool 
air and fast-falling dew. Bats, softly flitting out of the velvety darkness of a summer's night, attracted by the bicycle lamps or by the flying insects shown up thereby; supper at the inn; a last pipe, and a talk over the incidents of a long summer's day, ending with that wonderful evening rise. And so to bed, very tired, very sleepy and filled with deep contentment. 


\section{XI}

\section{SEA-TROUT IN THE SHETLANDS}

T ITTLE TOM, the Water-Baby, was driven out of the river where he passed his early years by the effect upon the water-world of a hot summer culminating in thunderstorms, and by the used-up, oppressive atmosphere that goes therewith. There is a certain time in every year in the valleys of South-country chalk-streams when that same used-up feeling tends to oppress; even the evenings and the nights cease to be cool and to give relief. Then -it may be towards the end of July, it may be early in August-come memories of purple heather and of green bracken, of bog-myrtle and cotton-grass, of springs of icy-cool water in spongy emerald turf in nooks on the mountainside, of great granite boulders, lichen-covered, and of clear rapid streams swelling to turgid torrents in their rocky beds in July and August spates; of those same streams fining down again to clear amber-brown, streaked with foam- 
bubbles, and of sea-trout in the deep pools and in the rapid runs. Above all, of the pure and keen air coming up the strath or over the moors and lochs, fresh, like the trout, from the sea.

There is something about the play of a seatrout that you get in no other form of fishing with the fly. No one who has seen them shooting up a high fall, which salmon after salmon has failed to negotiate, can fail to marvel at the tremendous energy and muscular power bottled up in their shapely forms. You get the full benefit of that energy when you hook one on a fly. But let us put off the memory of such struggles till we get to the recital of the landing of a big one, not "freshrun" but, better than that, not even run at all, still in the sea water of a Shetland voe. They are then in the full vigour of their life in the sea, of which element we are tempted to believe the tale that it is the mother of all living things in this planet. Charles Kingsley, from whose writings it is so difficult to avoid quoting in a book on fishing, seems to have held that view. "Tom," the Water-Baby, when the fresh river water turned salt all round him in the mouth of the estuary, "felt as strong, and light, and fresh, as if his veins had run 


\section{SEA-TROUT IN THE SHETLANDS 123}

champagne; and gave, he did not know why, three skips out of the water, a yard high, and head over heels, just as the salmon do when they first touch the noble, rich salt water, which, as some wise men tell us, is the mother of all living things." The President of the American Natural History Museum, according to a Press report of March 1918, put forward the conundrum whether life "is solely physicochemical in its energies or whether it includes a plus energy or element which may have distinguished life from the beginning." I apologize for the polysyllables. Most fishermen would, I know, prefer the language of the poet to that of the scientist to describe the upward evolution of life, in ten million centuries or so, from the ingredients of sea water to man:

A fire-mist and a planet, a crystal and a cell,

A jelly-fish and a Saurian, the cave where cave-men dwell; Then a sense of law and beauty, and a face turned from the clod.

Some call it "Evolution,"

And others call it "God." (W. H. Carrieth.)

I should like to know the man who wrote that. But to get back to the scientist: he explained that existing sea water is an ideal chemical medium for life, as its chemical compo- 


\section{MOSTLY ABOUT TROUT}

sition strongly resembles that of the blood serum of the higher animals.

Of the marvels wrought beneath the sea upon the growth and vigour of the salmon, the trout and the eel, our three river fish that spend so much of their lives in salt water, there is no doubt whatever; and if you want your veins to run champagne, and yourself to feel strong and light and fresh, the sea-trout of Scotland or the isles will give you every opportunity of acquiring that feeling.

My first experience of sea-trout fishing was on a loch in the west coast-a lovely day in glorious scenery. We were on a walking-tour (passed mostly either in a boat or on wheels), and we were spending the last night with a keen fisherman and most kindly of hosts, now gone to his rest. We were to be met by a yacht the next evening, to sail homewards past the sunset glories behind the islands of Rum, Eigg and Muck-but it is of fishing I am writing now, not of that sail homewards. Our host mentioned after dinner that he was fishing for sea-trout the next day and would one of us care to come too? I waited, silent, with my heart in my mouth, and much to my joy no one else was keen on fishing, so the lot fell to me. There was a nice fishing ripple. 


\section{SEA-TROUT IN THE SHETLANDS 125}

At first I found casting from a boat with a long rod rather awkward, but soon got into it, and landed, or rather "boated," thirteen sea-trout, averaging two pounds. It was one of those days, like my first with brown trout, when they attached themselves without any skill on my part, and, obviously purely through luck, I caught several more than my highly skilled host. Though the surroundings were very beautiful, my first experience of loch fishing did not impress me as being very high up in the scale of sport. The sea-trout played vigorously, it is true, but my rod must have been thirteen or fourteen feet, as sea-trout rods ran in those days, and there really seemed to be no reason why a fish should ever be lost when once hooked on such tackle. There was the whole loch for him to play about in, and plenty of line on the reel. Only one gave any excitement, by an expedition under the boat and a run on the other side thereof, but the gillie spun the boat round skilfully, and luckily the line did not catch in a splinter of wood on the bottom. Certainly the fish were a goodly sight, washed and laid out on the grass where we had luncheon; but I do not feel inclined to dwell on the subject of loch fishing from a boat for sea-trout, though $I$ have since some- 


\section{MOSTLY ABOUT TROUT}

what modified my opinions upon the amount of skill required.

After that experience other sea-trout days stand out in my fishing memories, of rivers, both on the west and on the east coast of Scotland. In the west, especially a day on the Lyon, on the late Lord Strathcona's water, in wonderful scenery and surroundings, where they took a "teal and black" (with silver twist) fly well just where the salt water met the fresh. In the east, a memory of one of the most delightful fishing days I ever had. A tramp for many miles by road and heatherpath to the upper pools of a little river on the coast of Caithness. The delightful feeling of independence which goes with sea-trout fishing, and of reliance upon one's own resources and such skill as one may possess. That was a great day. There had been a heavy spate, which had run down, leaving the river in perfect order, and plenty of sea-trout were running up. They only came for about an hour in the day, but during that hour they came well, and it was a heavy basket that helped me to cover, without undue fatigue, a six-mile tramp homeward by short-cuts across the heather. The smell of peat-smoke from the crofts passed on the way home always brings back the memory 


\section{SEA-TROUT IN THE SHETLANDS 127}

of that day to me; so it does of a holiday spent in sea-trout fishing in the Shetland Islandsat which subject, after these many digressions, we at last arrive.

That summer had been one of great heat and of hard, strenuous work, with but short intervals for rest and none for recreation. Packing up, even for a holiday, seemed an effort, and a third-class railway journey in a crowded carriage, with several changes, was, if possible, to be avoided. That was easily done, by going by sea from the Thames to Aberdeen, a most restful proceeding in calm weather, and there changing into the smaller vessel bound for the Orkneys and Shetlands, then rarely heard of by the public, but now familiar, at least on the map, to all students of the long watch kept over us by the British (helped later by the American) Navy in the Great War. My companion on that holiday was none less than the first Commander-in-Chief of our sea forces in that war, who, at that time, had never had an opportunity of adding fly-fishing to his other strenuous recreations. I had been attracted to the Shetland Islands by a hotel advertisement holding out hopes of an average of thirty pounds' weight of sea-trout in a day, taken on the fly, in lochs within range of the hotel. 


\section{MOSTLY ABOUT TROUT}

Lest I should cause a rapid migration of anglers to the same resort, I had better mention at once that the total weight taken by the most fortunate fisher at that hotel in five weeks was about fifty pounds, and I am firmly convinced that a large proportion were not caught with fly, but by trailing a spinning-bait in the saltwater lochs or "voes" in rough weather. These voes are arms of the sea stretching far inland all round the Shetlands, so that the coast-line itself seems to be about a hundred times the length of the circumference of each island, measured across the mouths of these voes.

We arrived at Lerwick at about 11 p.m. We did not quite have the experience of a view of the midnight sun, but I remember sitting at my bedroom window at the hotel, overlooking the harbour, after 11.30 p.m., reading a letter in broad daylight. Next day we drove about twenty miles by post-cart to our destination, supped, and were told our place on the roster with the other rods for the following day's fishing. There were eight men in the little company, and one lady, who possessed the attribute, priceless in so remote a spot, of great skill and experience in the tying of flies, of which such patterns as teal and red, 


\section{SEA-TROUT IN THE SHETLANDS 129}

teal and magenta, grouse and orange, and Zulu were in the greatest request. The next formality was the engagement of a gillie, an essential luxury, if not for any other reason than because without one it would be impossible to find one's way to the different beats, or to fish them if we did, as it was all boat-fishing, either in the deep voes or in freshwater lochs, of which the sides were unsuitable for wading. And now, at last, for the great experience of that holiday.

We started soon after breakfast for a tramp across heather to one of the nearest of the voes. They seem more like inland lochs than arms of the sea, winding, as they do, for many miles inland between heather-clad hills. The sea-trout in them take, if they take at all, fairly close to where small streams come down to the sea from the freshwater locks. These little streams meandering through the peat-beds can barely be described by the name of burns; they are better described as ditches. The voes were generally ruffled by a breeze, and we fished the shallower voes as one fishes a loch, pulling up to windward and drifting broadside on, if there were two rods in the boat; stern foremost, so as to be able to hold the boat against the wind, if there 
was only one rod, who could thus dwell on the best places and miss none of the water by drifting while putting on a new fly or cast. It is essential, when fly-fishing in salt water, to use eyed flies. A little spot of brown rust forms just where the gut touches the hook, and very soon the fly drops off, if exposed to the least strain; with eyed hooks you can get over the resultant danger of a break by re-tying the fly to the gut, cutting off half an inch thereof every time you do it, which should be at least every quarter of an hour.

This was a different sort of day: a bright one, with no wind, and perfectly calm, clear sea water-so clear that you could see every little pebble and shell on the bottom in three fathoms of water. The whole of that voe is of almost that depth, rather deeper in parts, excepting round the rocks and waving beds of umber-brown seaweed attached thereto. It was so calm and still that the smallest rattle of oars in rowlocks seemed to vibrate all over the glassy surface of the bay. Our plan of campaign was to muffle the rowlocks and to paddle gently and aimlessly about, throwing a long fine line as lightly as possible, letting the flies sink well, and then drawing them, 


\section{SEA-TROUT IN THE SHETLANDS 131}

hand-lining in enough slack line to enable the rod to lift the remainder for the next cast, and then "shooting" the slack line from the hand when the cast gathered forward momentum -badly described, but the usual way of fishing for salmon when you want to put out an extra yard or two of line.

We did nothing for several hours, possibly because the tide was wrong. Then we saw a boil on the surface, close to the rocks and brown seaweed. The gillie turned the boat round and backed me, kneeling, full of excitement, in the stern sheets, towards the spot. My rod was not a long one, only about ten and a half feet, a rather stiff greenheart. It threw a very long line, but, in my hands, it could never achieve a short one. The line was tapered, a thin one, but heavy for its thickness; the gut-cast a very fine one, necessarily so, on such a bright day, in sparkling clear sea water. The boat was handled skilfully. I always think that in boat-fishing more depends upon the man with the oars than upon the man with the rod. Suffice it to say that the flies were presented to the vision of the fish without his having seen, or been frightened by the sound of, the boat. The next thing that I knew was that my reel was screeching, the 
handle spinning so quickly that it became invisible. It was not one of the modern reels with big drums and adjustable check that rejoice the fisherman of to-day. The spindle was thin, and the check, which worked with the same power when reeling in or letting out line, made a tremendous noise; almost like the rattles used by small boys to frighten birds off the crops. A very noisy and very inspiriting sound.

That first rush, tearing line off the reel, was terrific. It was comforting to know that there was plenty of "backing" on the reel, strongly spliced to the end of the silk casting-line, and soon the backing began to show. The fish seemed to be making for the open sea at the mouth of the voe, several miles distant. Then came disaster. I held the rod-butt a little too close to my body. The handle of the reel, still spinning madly, just touched my waistcoat. It felt like only a little flick, but with a big sea-trout still in the momentum of his first rush and a long and heavy line towed behind, keeping the fine gut as taut as a violin-string, it was enough. I reeled in sadly, put a fresh point and fly on the cast, and sat for some moments silent, in blank despair, not daring to glance towards the gillie. So passed the morning. For some time we saw no sign of 


\section{SEA-TROUT IN THE SHETLANDS 133}

sea-trout, and went back to the old method of chucking and chancing it by the former unsuccessful method, keeping up our keenness, but with little hope of another such chance. Well, it is always worth while to stick it in sport, as it is in everything else. Luck may change. On this occasion it did. The sea was still as calm as the proverbial mill-pond; we had been watching the edges of the banks of brown seaweed for more rises without result. Then I happened to look in another direction and saw distinctly another boil, not near the rocks, but well out in the little bay. It was difficult to fix the exact spot on the face of the water; we could get the direction of an object on shore to steer by, but the difficulty lay in deciding how far off the fish had risen, after all indications had disappeared from the surface. Then, again, it was some way off, and there was some chance of the trout having moved if we did not row hard to the place, and a certainty of his being put to flight if we did row hard, thereby rattling the rowlocks and making a wave on the surface. I do not know, by the way, whether such a wave affects trout in the sea as it does in a pool in a river, but it was enough to think that it did. We effected a compromise, rowing as fast as we could, 


\section{MOSTLY ABOUT TROUT}

combined with all the gentleness attainable in handling the oars.

When, as we thought, about fifty yards or so from the right spot, we turned the boat and the gillie backed it, gently as before, for me to cast from the stern. It was well that we turned when we did. By inconceivable good luck I got that sea-trout on the very first cast; he took the dropper fly, deep down in the water, as I was reeling slowly in before gathering up the slack more rapidly with my hand in readiness for another cast. Then came a most glorious tussle, to the accompaniment of a constantly screaming reel. A steady wind-in with fingers lightly touching the handle, very lightly, ready to let go instantly and so save a break, when the check began to screech again with the next mad rush-and there were many, two of them ending in a leap out of the water. That is always a moment of moments. I read once that whether on such occasions you ought to lower the point of your rod to ease the strain or not depended upon whether the fish jumped head away from you or head towards you. There was no rule about what to do if he jumped across the line of direction between rod and fish. All I know is that I always lower the rod, instinctively, 


\section{SEA-TROUT IN THE SHETLANDS 135}

if a fish jumps, and I never remember having lost one thereby, so these were the tactics pursued with that Shetland trout.

When the mad rushes were over, there came a heavy strain on the fine gut, the fish playing very deep in water. Then came short rushes, the spray spouting in a sort of $\mathbf{V}$ on the surface where the line cut its way through the sea. Then a steady but severe strain, the rod bending to it. The gillie backed me slowly to the fish just at the right pace to enable me to reel in the line, and soon we could see the fish astern of us, swimming upright and apparently not the least incommoded by the full power of the rod. I shall never forget the view of his broad, greyish back, or the feeling of helplessness, and of wonder whether I should ever get him into the boat or whether the usual spot of rust was rotting through the fine gut-point. A quarter of an hour had passed away, seeming like a week. I will cut short the remainder of the tale, only adding that, in the end, the fish swam past the boat still upright and apparently still full of fight; the gillie hastily shipped his oar, and scooped him out just as I shouted to prevent him from attempting so $\operatorname{mad}$ a venture. He was a short fish, broad and very deep, and he weighed just over $4 \frac{1}{2} \mathrm{lb}$. 


\section{6}

\section{MOSTLY ABOUT TROUT}

There were other days, successful and unsuccessful, in freshwater lochs and in the sea voes; days of storm and wind and days of sunshine, but that was the climax : to describe the others would be but tame. On several days more sea-trout were caught, but much more easily, once eight in half an hour; but that one big fish on the finest gut on a bright sunny day was by far my best experience of sea-trout in the Shetlands. Every scream of the reel, every throb of the butt, remains fixed in my memory. It happened in '98, nearly twenty-three years ago. How time passes! The usual "tag" on that subject is old Horace's :

Tempora mutantur, nos et mutamur in illis.

That the times have changed for the fisherman is true. Trout are more fished for, and more wary, which is all to the good for the older generation of fly-fishers, providing for them, as it does, new difficulties and new interests. But have we changed much ? I scarcely think so. Not, at all events, in the excitement and delight of a struggle with a Shetland sea-trout. Perhaps in one way, in the competitive spirit. I retain a memory of satisfaction that my four and a half-pounder on the occasion described was the only one on the big dishes put out for 


\section{SEA-TROUT IN THE SHETLANDS 137}

the evening display in the hall of that hotel. All the other rods had had a blank day.

To prove that such a feeling has passed away, I will describe the fly that I have found far better than all others, not only on that occasion, but always when fishing for sea-trout in salt or brackish water, and even up a river. No wings, a soft hackle, rather short, of a smokygrey, and a silver body, not of tinsel but of dull silver twist. And may it provide for others as good times as it has for the writer! 


\section{XII}

\section{"MY ENEMY"}

$\mathrm{T}^{\mathrm{T}}$ is September, near the end of the trout1 fishing year in these parts, and it is raining softly and persistently from a grey sky. All the colour has gone out of the landscape, and all the glory of the water-meadow flowers. I am standing at an elbow corner of a chalkstream, where the river flows evenly down to the corner, washes against my bank, and then goes on its way downwards through the meadows. On the opposite side is a copse of alders, with a rank undergrowth of coarse grass and rushes; my own bank is clear of obstructions to the fisher, with the exception of a big willow which hangs over a deep pool about seventy yards below me. I am thinking of "my enemy," and missing him sorely. He was a very big trout, and the thought of him brings back memories of nearly every fishing day of last year's season. The glamour of a long campaign between us, which ended in a 
final terrific battle just a year ago, still hangs over the spot. I fear that I shall never see the like again, and I wish that the struggle had been prolonged over more than one year.

It was in the month of May last year when I first saw this stream. After an interview with the friendly owner of the mill, I walked up the left bank, splashing through the copse on the other side, which was then half under water, and I saw the noses of several great trout coming up to make selections from amongst fleets of flies which were floating down from the weed-beds above. I never saw such numbers and varieties of flies. This bit of the stream had then been long undisturbed, and the weeds had not been cut for several years. All the water-creatures had prospered abundantly and plentiful food had made the trout exceeding fat. Next day found me, with leave to fish, working up the bank to the corner at which I now stand, and contemplating a broad nose coming up at intervals to take a fly. Creeping up on my hands and knees, I could see the great trout himself, by peering through the sedges into the clear water. I had not seen a dry-fly stream for some years, or trained my eye to judging the size of trout, but I realized at once that $I$ had reached the first 
stage in progress towards my great ambition, to take my first three-pound trout on a dry-fly. I judged his weight at three pounds and a half and his condition perfect; hog-backed, of great girth compared with his length, measured from the slowly opening and shutting pink mouth to the gently waving broad, square tail. Such a fish! Slow in movement, with the dignity and the proportions of an alderman who has prospered exceedingly. And now, after the reconnaissance, for the opening of the great campaign.

Not having fished for some years, I had forgotten the secret of using for big trout the very best and strongest tackle to which they can be lured into attaching themselves. I ought to have remembered that I was dealing with an unsophisticated fish that had never seen an artificial fly. I used an old cast, the finest I had, of "four-x" gut, and the year of its purchase was not a good one for strength of gut. He took my fly at once. Directly he felt the hook he made a terrific rush up-stream through what looked like an impenetrable weedbed, leaped high out of the water in a clear pool beyond, and the line came back, less the fine point of gut. I reeled in sadly and tried my luck elsewhere. Next time I saw his broad 
nose come up he took my fly again with confidence. Again he made the same mad rush, followed by a jump, and again he broke me. These were the opening combats of the war, and in both of them I had failed.

Then came many weeks of prolonged and patient warfare. I could only get away in the evenings, generally about twice a week. There was always a hatch of fly soon after sundown, and I could make sure that he would then be feeding. During the summer months I must have spent on an average at least an hour and a half in every week trying to induce him to take my fly again. Out would come his nose every few minutes, sometimes two or three times a minute, but always to take the natural flies, which I had done my best to copy in the pattern selected. He would take them freely and frequently, without, as far as I could tell, even glancing at my copy, which constantly passed within an inch of the spot where his nose was appearing (it was a very easy cast, right-handed, from a point below him, a nice strong flow to carry the fly down, and not a vestige of "drag"). So the weeks went by. Then, one day in September, near the end of the season, I broke my landingnet in trying to bend down a bough of a tree 
on which my fly had caught. I managed to find a weak toy substitute, which I took with me for the evening rise, and found "my enemy" awaiting me as usual, rising freely and confidently. The usual game began. I think that I must have put eight or ten different flies over him, and he still rose confidently and constantly at every natural fly on the surface, ignoring altogether the artificial. There was a great rise of fly, as there always is after rain on this stream, and the road drainage had coloured the water to some extent. It was not, as it generally is, as clear as gin.

My enemy went on steadily rising to natural flies after I had succeeded in placing exactly above his nose, and also an inch or two on either side of it (in case he should be blind in one eye), what seemed to me to be exact copies of the fly on the water. He must have seen every one of the eight or ten patterns I tried, some of them three or four times, and still he rose. The light was failing and I was giving up in despair, as I had many times before during the season, when I determined to make just one more effort, using a fly as unlike as possible to anything he was taking. I put up a pink Wickham, tied on a hook of size 0 . In sheer weariness I made a poor cast, the fly dropping 
in a position which brought it several feet to one side of the fish. He came across at it, took it confidently, and dashed towards the weed-bed up-stream. I knew that he meant to bore through the weeds as usual and break the gut by a jump in the clear water beyond, so I put on all the strain that I could, determined to force his head down-stream before he could achieve his purpose. The little rod bent nearly double with the effort, and a break scemed almost certain, when at last the pressure began to tell. His pace slackened. He came to rest. His head turned, and soon he was boring steadily down-stream, trying to get his head down the whole time and to turn upstream into every weed-bed we passed during our progress; but I hauled him by main force, and gradually guided him towards my bank. It seemed as if he would never tire. Once or twice he headed round, and regained almost his full strength directly he met the current again. At last I managed to guide him under my bank, shifted the rod to my left hand, keeping up the strain, slipped the landing-net into the water below him, and tried to head him into it. He saw it, or me, and was off at once, well into a weed-bed. The strain was no longer a live one; it had become dead and steady. 
I believe in the theory that chalk-stream trout, when hooked, sometimes seize hold of weeds in their mouths in order to gain a purchase and prevent their heads being turned downstream by the rod-pressure. I put all the strain on the tackle that I dared, without result. There was still a dead pull. Then I bethought me of the dodge of hand-lining. I stepped back, pointed the rod at the weed-bed, took the line between finger and thumb, and gave a series of little tugs. After three or four of them, the strain again showed life, brought about, as I believe, by the little tugs having compelled the fish to open his mouth and let go the weed he was holding.

Down-stream again, as before, and across gradually to my bank. Another attempt with the landing-net, and another failure. This time no weed-bed available. Then the down-stream course again, followed by another try with the landing-net; but it was too small and shallow to lift out the great trout, and away he went, thoroughly scared this time, and boring up-stream for several yards before I could turn his head down again. Then steady downward progress towards the big willow-tree growing on my bank over a deep pool. He was making downwards of his own accord then, perhaps 
knowing that I could not follow along the bank farther than the willow, and that the water under it was too deep for me to take to the stream and follow by that route. My plan of campaign, like Moltke's, had not provided for the enemy's procedure after the initial stages, and a new plan had to be improvised. I determined to put the issue to a final test by hauling his head to my bank when still a few yards above the deep pool under the willow, and to try the landing-net once more. He bored on down the middle of the stream. The decision had to be instantaneous. I put everything on one venture, hauled him to my bank before the water deepened, tried the landing-net again, and failed to get him into it. He got clear, plodded a yard up-stream, and dived into the weeds. Then, as a last resort, I threw the rod down in the meadow-grass, waded into the water, followed the line of the gut into the weeds, groped with my hands amongst them for the fish, touched him lightly with the tips of my fingers, moved them gently up his sides, feeling with dismay the great breadth of his back, and wondering whether I should ever get a grip of him, or if he would bolt before I could get near to his head. Gradually my hands got to his gills, and then, with one hand 
gripping from above and the other lifting simultaneously from below, I gave a great heave which sent the fish on to the bank just clear of the water. Splashed all over, and with arms and sleeves soaked, I struggled to the side, climbed out, heaved him further into the meadow, lest he should kick himself back into the stream, followed him up, and gave the coup de grâce with a pocket "priest." The fly was still in his mouth; he was well hooked in the lower jaw. He weighed three pounds and half an ounce, so I had achieved my ambition.

Standing, a year later, beside his favourite feeding-place in the bend of the stream, I miss my enemy sorely, and wish that the campaign could have lasted longer or ended otherwise. I wonder whether I played the game quite fairly. Tickling trout is poaching; but is it allowable to land one in that way when all other methods have failed and the fly is still in his mouth, with line attached? Was I a true sportsman? Can he, from the Valhalla of gallant fish, reprove me by exclaiming " $\mathrm{Bad}$ form!" as did the Pirate King to Peter Pan, who had propelled, by a kick from behind, the final leap of the Pirate into the ocean? 


\section{XIII}

\section{A FISHERMAN'S FALL}

T TAKE it that between all true sportsmen 1 and their quarry there is a certain unwritten contract between pursuer and pursued. The fox-hunter does not go forth to slay foxes with lethal weapons, but to watch hounds hunting and to keep with them if he can. The game-shot does not stalk his birds and shoot them sitting. The stalker does not use a Lewis gun to pump lead into a stag at short range. So, between a dry-fly man and a trout there is an understanding on both sides. The trout may flee to cover if he sees man, rod or line; he must be shown only the fly and a link or two of finest gut. Not only that, but the fly must float cheerily and independently, as if alive, and there must be no sign of its being dragged by the floating line in any direction out of the natural course followed by the living insects poised on the little eddies and swirls on a chalk-stream's surface. Whether the arti- 


\section{MOSTLY ABOUT TROUT}

ficial fly need bear any resemblance to what it is supposed to represent, excepting in size, shape and movements, is a debatable point about which some fishermen discourse on paper, but whereon none would dare to express his innermost thoughts in the Fly-fisher's Club. So much for the dry-fly fisher. But what about the trout? There are two sides to every contract, and if the fisher on the one part is bound by rules and etiquette, what of the fish on the other part? If trout in dry-fly water never rose to take food on the surface, the fisherman might as well prove his skill in casting by dropping his fly lightly into a wine-glass on his tennis lawn, against half a gale of wind, standing a yard or two in front of the high netting surrounding the court. That would be interesting. It would not be fishing. This is the story of a fish that never, to the knowledge of any human being, came to the surface to take food. If that is his part in the contract with the brotherhood of sportsmen, what should the fisherman's part be, assuming that the sport of fly-fishing includes, even if only occasionally, the catching of fish ? But I will tell the tale of this trout.

My favourite haunt from May to September is a spot already described, a tumble-down 


\section{A FISHERMAN'S FALL}

mill of beautiful old red brick, roofed with lichened tiles of lovely colours which only great age can confer. The river below the mill runs through an old garden, a pathway crossing the stream just below the building where the water races out from the mill-chamber. Below this little bridge the water is deep, forming a little pool, but it soon runs off on to about thirty yards of gravel-bottomed shallow, overgrown with large willows. Then it passes under an old stone bridge, dating from the days of King John. So much for the water below. Wading up the shallow, it is an ideal cast upstream as far as the place where the water runs out from the mill, but there the little bridge is only about twelve inches above the surface of the river, and the most skilful fisher cannot get his fly far up the little tunnel.

Leaning over the rail of the little bridge, you can practically always get a view of the waving tail of a very large trout, invariably at least two feet below the surface. There is a legend amongst the family that dwell in the mill that once upon a time the fish dropped far enough down-stream to show his whole self, and that he was bigger than a big one I caught in the mill-pool above. (That weighed $3 \frac{1}{2}$ lb.) Personally I cannot vouch for his size 


\section{MOSTLY ABOUT TROUT}

at this stage in the story. I could only see about four inches of his tail, and the most experienced cannot estimate the weight of a fish from a vertical view of his tail, whatever may be guessed from a side view thereof. He was clearly a big trout: let us leave it at that. Now let us reconnoitre the position from above. You can do that with me, if you have made friends, as I have, with the mill family by saying how much you enjoy watching the children bathing in the little pool below the footbridge, especially when the evening rise is on, on a hot sunimer's evening. Not.so difficult a thing to say during this past season; when I can remember no such summer's evening.

Just above the footbridge you pass, by a small door, into the dark mill chamber. You hear the water gurgling under the floor, as you cross it, and a little shaft of light comes through a sort of window above the hatch beside the mill-wheel. You can open a door on the hatch side of the room and look through it up a grassy path leading through the copse beside the mill-pool, making a lovely little picture in the sunshine, as seen from the darkened room. But to business : we are after that trout. When the hatch is open the whole river, from a glassy slide of clear water, so clear that you can imagine 


\section{A FISHERMAN'S FALL}

that you see the bottom with no water intervening, turns into a raging torrent of tumbling water and foam. It is quite a small river, really, but a somewhat terrifying thing to have the whole of it in a dark room with you, until you get accustomed to it. You cannot close the hatch; it is out of repair. Below the hatch you can see the water running below you for about three or four yards, then it disappears under the floor. There is your problem. Four yards of river running at your feet, then passing under, say, five or six yards of the floor of a room, then under about two yards of footpath; under the path a big trout, inaccessible from below, feeding upon minnows and upon anything else that passes within its vision, well below the surface. So much for the reconnaissance, and now for the plan of campaign of a one-time dry-fly purist. The first operation must be to hook the fish; let us, lest we fall too low in the scale of sportsmanship, concede one point-we must hook the fish on fine gut. The obvious course open to the enemy will then be to pull. We shall find ourselves in a room, fishing over a hole in the floor in a river which then runs through a tunnel, the rod doubled up, a big trout at the end of the line, and not the remotest chance of exhausting him or of hauling 
him up to our feet to land him, if we did. We must try another plan.

The rod, being meant for casting, or for landing a fish, is clearly of no use here. We cannot cast in a room with only a hole in the floor to cast over, and we cannot land the trout where we stand. We take the whole line off the reel and leave it in the room, carry the rod down-stream, and prop it on the bank beside the shallow, about fifteen yards below the mill. So far, so good. Then we think of the next move. We tie a big cork to the end of the line that had been round the drum of the reel, and coil the line down carefully on the floor of the room, so as to run freely away downstream if required. Then we do the deed, first carefully searching the surroundings to make sure that there are no spectators. We attach to the fine gut something-I will not say what-that resembles, or maybe is an actual specimen of, our trout's usual diet. Let us call it, with so many writers on angling, a "lure," and leave it at that. We lower the lure carefully into the boiling torrent, which sweeps it swiftly down for a few yards, and then we gently pay out line-we know exactly how much is required to reach the fish, as we have already measured the distance and marked 


\section{A FISHERMAN'S FALL}

it on the line with a little twist of paper. We can hardly breathe for excitement as the paper gradually approaches our fingers-it passes through them: no result. We let about two or three yards more of the line go down-stream, in case he has followed the "lure." No result. We recover about six yards of line, very, very gently, and wait for a while. Then we pay out again. This time, just as the paper comes to hand, we feel a gentle tug. Luckily, we just succeed in keeping, without the aid of the rod, only just enough strain on the fine gut to avoid a break, and then at once we pay off all the line, cork and all, as quickly as we can, into the hole in the floor. Before we can catch the fish we must catch the cork, so we race to the place where we left the rod, wade out into the stream, and wait. In a few minutes, here comes the cork! It comes bobbing down under the little footbridge, and is carried into a backwater under the wall on one side, where flotsam and jetsam collect. We get the rod and secure the cork therewith. It seems to take a week to detach it from the line, to pass the line carefully down through the rings on the rod, fasten it round the drum of the reel, and then to wind in, standing in the shallow water well below the mill. At last the raised rod-point begins 


\section{MOSTLY ABOUT TROUT}

to lift the line out of the water. Soon we shall know whether there will be a live strain thereon. We must be fast in something. Is it the trout, and if so, is the line clear or caught up? Soon the gut is lifting; it nearly touches the underside of the little bridge. We move the rod downwards across the stream, keeping the point low, so that the gut shall clear the bridge, andhe is on! There is no mistaking the thrill of the butt. It seems that he will never give to the steady strain. He is deep down, and well up the tunnel. At last he has to turn his head, and the battle follows its normal course. Down the long shallow he comes, and well below him I keep, until, in a shallow backwater just above the old King John bridge, he comes to the net-4lb. 2oz., by the spring balance, and a well-shaped beauty.

At this point I woke up, went to breakfast in the Fly-fishers' Club, and looked my fellowmembers in the face. I had fallen as a flyfisher only in a dream. The next day I returned to the country, and watched the tail of that trout still waving under the little footbridge. Shall I be likely to fall while waking ? I wonder. There are only two or three days to the end of the trout-season in these parts. 


\section{XIV}

\section{A GRAYLING DAY}

THERE is no word in the language for 1 the silent, sliding flow of a large chalkstream. Running water has its charms for many besides the fly-fisher, but for him the greatest charm of all, and some day, perhaps, will be fulfilled my remaining ambition in life, to spend a whole year in fishing. January will find me casting a wagtail bait for pike in this stream farther down its course, where there are but few trout, and war is not waged upon other fishes with net and with wire, as it is here. February and March shall be spent in the North of Scotland, "up the strath" of the spring salmon river of which I know every pool. There I shall see again the wonderful variety of bird-life and hear the long-drawn note of tha curlew, that most healing note in nature. April in North Devon by Taw or Torridge, wading and fishing wet for small trout, and wondering at the beauty of the woodlands, 
the banks of wild daffodils and the notes of birds. May, June and well into July by a chalk-stream, fishing dry-fly and loving every minute of the long days and the glory of the water-meadows and copses, the birds in full chorus. Maybe it will be a wet July, and the weather reports will tell of heavy rain in Scotland. Then will come thoughts of sea-trout rising in streams clearing after a spate. A few weeks in Scotland, and then, choosing calm weather, a trip by sea from Aberdeen or Wick to the Shetland Islands. Sea-trout again, but this time fishing from a boat in the clear sea water of the sheltering "voes," casting a long line with a small rod and sinking the flies, or perhaps in one of the freshwater lochs. Then back to the South-country chalk-streams for the grayling in October and November, perhaps part of December; and then the pike again. What a year, and what a variety of waters! -flowing, gliding, running, rushing and rippling; breaking, perhaps, if we should get a strong blow into one of those Shetland seawater voes or exposed freshwater lochs. But here we are in October after the grayling. A bigger rod than the little greenheart I use in the small dry-fly stream I fish for trout, where everything is in miniature excepting the trout 


\section{A GRAYLING DAY}

themselves, monsters of their kind. This is a big river, and the grayling rise all over the wide bits, which are unwadeable in parts, needing long casting. A split-cane rod with a history extending over a quarter of a century, and, to tell the truth, only the middle joint of the original. There are memories of the old butt, which used to spring differently from this one, nearer to the hand. That butt was smashed in Breconshire, the day when I was carried off my feet, wading in the Usk, and fell into deep water, still gripping the rod (like a fool), and the butt broke between two rocks. The two original tops went in Brittany, not a fishing incident that time, but a smash when coasting downhill on a bicycle. You cannot break good split-cane by fair usage. The middle joint was only wounded, not beyond repair, in that smash. Once that joint took its part in the greatest exploit of this special rod, the landing of a six and a half-pound salmon in a river on the West coast of Scotland, a very " red" and very sulky autumn fish that took a small sea-trout fly. The fly- and cast-box also has its history; it was designed specially and given to me years ago by the best fisherman I know, at his wedding, when I was his " best man," a position I could not claim by the riverside. But the reel has 
a story, too; so has the old line: I must give up these digressions and get to the grayling.

I used to live in this happy valley, tucked away in the Wiltshire downland. The two best times of the year here are the spring, with all the fruit-blossom out, and the autumn, with the golden withy-beds and the glorious tints of the beech woods above them. I get there on a bicycle now, and this morning the whole scene is at its best. There is still just a trace of the rime of last winter's frost on the dead leaves lying on the shady north side of the hedges, and the cobwebs are all laden with moisture. There is no wind; the blue smoke goes up straight from the cottage chimneys and hangs in long filaments against the glory of the beech woods, which blaze with colour in the October sunshine. The bright tints melt into delicate blues and greys up the valley in the distance. Now we pass the old red manor-house and the little thatched houses and farm-buildings of the lower village, the pleasant scent of wood-smoke in the air. Then a footpath takes us to a wooden footbridge over the river, and here is the place to leave the bicycle under a hedge, pull on waders and put up the rod. Soon we come to a big hatch, with the turmoil of heavy water below it. 


\section{A GRAYLING DAY}

Then deep, still water, not good for grayling; but there is a rise under the opposite bank. A long cast, only an inch from the bank and under some overhanging grass, but we get the fly there somehow. It is sucked under by a trout. I ought to have known better; but it was irresistible, and it might have been a grayling (I was almost sure it wasn't, really!). Back he goes, after gentle handling, and seems none the worse for his experience. Then along the bank, which is very wet, with about six inches of water over the short grass in places, and hence the need of waders. Soon we come to a bend where the water is shallower, a good place for grayling, as I know of old. They seem to congregate in special spots. There is always a big rise of fly this time of the year in this river, more than in the summer months, so the grayling are sure to show up soon. War was waged against them lately, I know, with nets and other devices; they breed quicker than the trout, and take the food intended for the fattening of their betters. Nothing short of dynamite will keep them down when once they get the ascendancy, so my instructions are to be pitiless, to disregard size, and to kill every one that I can take. A little fleet of flies is sailing gently down on the current, so 


\section{0}

\section{MOSTLY ABOUT TROUT}

they are sure to be up soon. There's a rise! There's another! There are two more, all within a few yards of each other! All unmistakable grayling rises this time, quick little sucking snatches, quite unlike any of the rises of trout, much as they vary.

All but one of the rises is within casting distance, and I get half-a-dozen grayling altogether at this spot, small ones, from about four or five ounces up to three-quarters of a pound. The bigger ones seldom rise to a dry-fly in these parts, though I know that there are some big ones about, up to two and three pounds. The seventh is better-a pound and a half. Then no more flies are to be seen, and no rises.

The bicycle-ride was a long one, the slackness of autumn is in my ageing muscles, and the step of a stile affords a convenient seat, so now is the time for luncheon. The ordinary sandwich is an abomination; not so the fresh mutton-pies of a pastrycook passed in the town at the foot of the valley, nor the new well-browned sticky buns, a sign of the return of peace to the land, the passing of the "substitutes." Yesterday was an apple-picking day; there is a wonderful crop this year, and grand weather to get them in, and my pocket contains samples of the best of the windfalls--a Cox's 


\section{A GRAYLING DAY}

orange, a Warwick pippin, and one or two little russets. Then a few minutes' rest, with an old pipe drawing well and plenty to look at. This part of the valley is a sanctuary for wild duck, and besides them the moorhens are worth watching; so are the water-rats, falsely so-called. Then over the stile, through a withy-bed, and the best place of all for the grayling, which are rising well again now. A wide shallow below a picturesque mill, with a few autumn flowers still surviving in the garden, the old church tower showing up behind, and alongside me, across a marshy bit trodden down by passing cattle, is the valley road, with a friend of old days passing occasionally and exchanging greetings and items of village news.

I spend an hour or so at this spot amongst the persistently rising grayling. They differ from trout in that way; it is always worth while going on putting the same fly over them, and nothing seems to put them down, probably because they stay deeper in the water, excepting just at the moment of a rise, and so see less of what is going on in the air above. The big fin and the air-bladder help them to come up almost vertically when they rise. I lay out my catch. Nice, clean, silvery fish, with a faint scent of wild-thyme. Each one glittered 
with colour when he came out of the water, opal tints on silvery pearl-grey, with dark head and back, which bears a violet fin shot with purple-red, as I have heard it described, I forget by whom. A nice full basket; some to be distributed to old friends passed on my way home, some to appear at to-morrow's breakfast; and excellent they are, split open, dipped in flour and grilled, and, when still very hot, a little lump of butter placed upon them, should there be any butter in these days of high prices.

And so back to our starting-place, to pick up the bicycle and pack the heavy waders thereon. Fishing days are short in October, and the evenings not as they were in the summer months. It is well to linger at the top of the rise, where the narrow valley widens out, and look back at the scene. The gorgeous tints on the woodlands are mellowing in the afternoon light. Distances are misty-blue, and the smoke of the village lies as a fragrant haze about the wooded slopes.

A haze on the far horizon, an infinite tender sky, The ripe fruit of the cornfield, the wild geese sailing high; And all on upland and woodland, the charm of the goldenrod :

Some of us call it "Autumn," And others call it "God." 


\section{A GRAYLING DAY}

The peace of autumn is over the woodlands and the water-meadows with their silver ribbon of winding stream, as we leave the valley and pedal homewards to tea by the fireside in the study, and a quiet evening with the winter consolations of "indoors," books and writing materials. Farewell to the fly-rod until after the turn of the year. 
XV

\section{BY THE STUDY FIRE}

T $T$ is not given to all middle-aged folk, 1 still less to those of "present-day" maturity (age not specified), to welcome the wild north-easter of winter or to take more than a vicarious interest in its lashing the hungry pike into madness. Such delights are seldom the perquisite of any who have spent forty years of life in all climates, and feel the results during the rapid changes of weather of England in the winter months. To such folk many of the consolations of life must be found during part of November, all December and most of January, by the study fire, or from what can be seen out of the windows. I am lucky myself in having windows both east and west, and generally there is something to be seen therefrom. From the writing-table there is a view of a magnificent old horse-chestnuttree, now naked and leafless, showing its beautiful proportions in black silhouette against 
the western sky. Not long ago it was clothed in the glory of great orange and yellow leaves. They withstood the gales and rainstorms of October, but suddenly, on a still November night, they all fell together, for no apparent reason, and in the morning they were piled knee-deep on the grass covering the roots. That was the first indication this year of the coming of the time of suspended animation for fishermen who are not in the full vigour of youth. It was a warm, still day, and the tree's discarded raiment showed up gloriously, gold, orange and scarlet, in the sunshine. Next day began a series of little blizzards with a powdering of snow, followed by damp, grey days; all the leaves have long been swept away to rot and to produce leaf-mould, wherein other plants will some day prosper. It seems a long time until the sticky brown buds at the ends of the twigs of that tree will burst in response to the warm sunshine of spring and to the pressure within of great pale green leaves and columns of pink blossom. Botanists tell us that those brown, sticky bud-cases contain the leaves already formed in miniature, and even tiny columns of pale pink florets. Hitherto I have been content to take on trust, based upon the experience of former years, the certainty 
that next spring will be as others; but one may as well experiment-it will be a nice thing to know for certain whether it is true.... I have just tried, and I commend the experience to others. I picked one of the buds, and cut it in half with a sharp knife. First came the thick, sticky brown outer case, with a lining of pale green, forming the counterpane of the bed in which the delicate flower-column is kept warm and secure from frosts; then some pale green blankets with soft woollen linings; then the baby leaves, smothered in silvery wool, and then the little column of pink babyflowers, each well protected from the cold by similar, only still softer, wool. And all that to be seen with the help of a pocket magnifyingglass! The thought arises of the other wonders which a proper microscope would disclose. I must try, some day.

From the study window to near the chestnuttree runs a lilac hedge, and that gives much more interest; not the hedge itself, which is too aged to flower or to produce more than a very few leaves, but the birds that frequent it. By the way, I wish that the bird experts would make it as easy as the botanists do for the ignorant amateur to find out what he wants to know without a prohibitive amount of labour 
and research. Every fisherman takes a delight in the birds that he sees and hears all the year round, whether he knows their names or not. Sooner or later he does want to know them; when he does, the first thing that he looks for is a list: $(a)$ of residents who are always with us ; $(b)$ of those who come to this country to breed; and $(c)$ of those who visit us in the autumn, winter and spring, but go elsewhere to breed. These three classes would do to begin with, and I do not know of any book, published at a price attainable by the average fisherman, that gives them. The other classes would be $(d)$ occasional visitors who used to breed here; and $(e)$ rare stragglers, seen, but never known to have bred here.

In case any brother-fisherman should find it of value, I will here give a list, prepared by an expert friend, of $(c)$ the birds that visit us from abroad in the autumn, winter and spring. There are fifty-five of them, and this is the list:

Perchers (11).-Redwing. Fieldfare. Black redstart. Robin (continental form). Greater or Greenland wheatear. Eversman's willow-warbler. Great grey shrike. Scandinavian rock-pipit. Lapland bunting. Heron Tribe (1).-Spoonbill.

HAWr Tribe (3).- -Honey-buzzard. Rough-legged buzzard.

Marsh-harrier. 
Duck Tribe (5).-Scaup. Golden-eye. Long-tailed duck. Velvet scoter. Smew.

Goose Tribe (5).-Bean goose. Berwick goose. Brent goose. White-fronted goose. Pink-footed goose. Swan Tribe (2).-Bewick's swan. Whooper. Plover Tribe (16).-Turnstone. Grey plover. Purple sandpiper. Green sandpiper. Wood sandpiper. Curlew sandpiper. Dusky or spotted redshank. Avocet. Black-tailed godwit. Bar-tailed godwit. Jack snipe. Great or solitary snipe. Sanderling. Little stint. Knot. Grey phalarope.

Gull Tribe (5).-Little gull. Iceland gull. Glaucous gull. Pomatorhine skua. Bouffon's or long-tailed skua.

Petrel Tribe (2).--Sooty shearwater. Great shearwater. Diver Tribe (5).-Little auk or rotche. Great Northern diver. Red-necked grebe. Black-necked grebe. Eared or Slavonian grebe.

I must confess that I have not seen any of these fifty-five out of my study window, but others may be more fortunate. I wish that I had space to add my friend's other lists of the 441 British birds (roughly, 267 "land" and 174 "water" birds), of whom 185 species breed in this country, the remainder elsewhere. Out of the whole 441 only six have so far accepted my standing invitation to visit the hedge outside; I suppose because I have not provided sufficiently varied fare, only coconuts cut in half, meat-bones (hanging), cold mutton-fat or lard (smeared inside the coconut 
shells when their original contents had been pecked clean), and the usual bread-crumbs and other scraps from the breakfast-table. I must provide hemp-seed for the seed-eaters, and nuts. Also fruit, when we have a good enough year for apples to provide a surplus; and, above all, a bath. Then perhaps more sorts of birds will come and keep company with me as I write at that window. Of the six who do come, taken in order of preferment, I put the tits first. A busy blue-tit always comes early, to investigate. He is generally to be seen before breakfast, if I have got over early enough the conviction that middle-aged folk are, like dormice, intended by nature to sleep snugly through the winter months, instead of forsaking a well-warmed bed to shave by candlelight in a cold room. The blue-tit can be counted on directly after breakfast. Two cole-tits, slightly differing from each other in their markings, arrive soon afterwards. Later in the day a big ox-eyed tit turns up, very definite and brilliant in colouring. I noticed that the smaller tits gave him a wide berth, so I looked him up in a book to find out the reason. It seems that he is fond of picking the brains of smaller birds, which probably accounts for his unpopularity. I have known eminent men in 
public life to be shunned for having, rightly or wrongly, acquired a similar reputation in their dealings with other folk of their own kind. I do not hesitate to mention this, because I have placed myself in the same category by giving the above list of bird-visitors, drawn up for me by a friend, who must have expended much trouble in its compilation. The list is of those who do not breed with us, so I have at all events kept my promise to him not to encourage pre-natal bird-murder, known as amateur egg-collecting.

After the blue-tits and cole-tits, my favourite amongst the bird-companions who venture close enough to my study-table to be intimately acquainted is a wren, always an attractive, busy-looking little person, with the wonderful trick of flying full-speed to within an inch or so of a solid trunk or an ivy-clad wall and alighting thereon as softly as thistledown. Next comes the old friend of our childhood, cock-robin, the boldest of all, especially if he finds you digging in the garden and likely to turn up something to his advantage. The only others that come near the window are sparrows and starlings, both reminiscent of a youth spent in towns, where I remember my first view, as a boy, of a starling that was attracted 
by some bread-crumbs spread for sparrows on a window-sill, and my delight in the rainbow sheen in his feathers in the sunshine. In the country they are too common to be a wonder to old or young, though the pale-blue eggshells, which, for some reason best known to themselves, they drop about the place later on, are rather a joy, both for their lovely colour and as a sign of spring. The starlings' table manners are not to be commended. They don't give their fellow-guests a chance. I have put them before those little reprobates the sparrows by mistake. Like all other reprobates, sparrows have many attractions, and no one who has been cheered in the remembrances of home by their appearance in other climes can help having a soft spot in his heart for them. Still, they do make war collectively against more attractive birds. I saw in a paper the other day that the best way to keep them off a bird-table is to stretch black cotton round it, as one does round the first crocus in the grass, in the vain hope that the wretched sparrows will thereby be prevented from nipping it off to get the drop of sweet juice which is then exposed. The house-sparrows do not trouble the tits in my hedge much, and black cotton is expensive, so they can investigate the mutton-fat and the 


\section{MOSTLY ABOUT TROUT}

lard, if they like-they cannot hang sideways on twigs and peck at it, as the tits do; so they could get very little, even if they cared about it. We have other bird-visitors in the garden, including bullfinches, greenfinches, chaffinches and a wee gold-crest. Also, of course, thrushes and blackbirds, the former a great joy for their winter singing; but they are not to be seen, as a rule, from the study fire, as they do not come for food by the window, excepting in the very hardest weather.

It is in the evening, when curtains are drawn and lamps are lighted, that the study fire itself is most attractive. A coal one is, of course, out of the question for all but millionaires, and so much the better. There is nothing in a coal fire that touches the comfort and associations of a fire of logs or of peat. The scent of peat-smoke always reminds me of happy fishing days in Scotland, Ireland or the Shetlands. Scents bring back memories more vividly than either sights or sounds, but it is of indoors that the peat-scent reminds me most, while the scent of wood-smoke brings back outdoor memories. A picnic on a Greek island, another in a beautiful wooded hill-side in North Devon, another on the west coast of Scotland, an evening halt after a march in the Soudan 


\section{BY THE STUDY FIRE}

desert, early mornings in camp in peace and in war, a shooting trip with the companionship of good sportsmen in Turkey, a fishing trip, camping out, in South Africa: memories like these crowd about the smell of burning logs.

Such memories, with the thought of outdoor days to come; help the fisherman through the long winter months. And, after all, they are not so very long. Most of November, all December and, in most years, the whole of January. Even on those grey days which take the colour out of everything, there is always the arm-chair, the pipe and the bookshelves, with their inexhaustible store of inspiration from those who thought great thoughts and did great deeds in the past, and from the folk who are doing the same to-day. The study fireside is like the banks of a trout-stream in one way: only exceptional human companionship is desired there. But well within sight of my chair are portraits of four men, great both in public and in private life, who have honoured me with their friendship and inspiration: a British statesman, a Field Marshal, an Admiral, and a Prime Minister of a new nation. Three of them are keen fishermen, and the other would have been, if he had ever had the chance. Three of the four are living, so names must not be men- 


\section{MOSTLY ABOUT TROUT}

tioned. Everyone has his own little collection of friendships with those greater than himself, whose influence (unconsciously exerted) helps in the defeat of mean and petty motives and in keeping standards high, even if unattainable.

Then, for the fisherman, there is always the consolation in spare moments of overhauling tackle, oiling reels, sorting and rearranging flies, discarding old gut and such-like activities, to prepare for fishing days to come. Some have enough leisure to tie their own flies. For all, whether fishermen or not, some form of production, by hand or brain, is essential to contentment. A sense of achievement, or even of effort resulting in failure to achieve, is the best form of soporific when laying one's head on the pillow to pass in forgetfulness some of the hours that intervene before the opening of a new Fisherman's Year. 


\section{PART III}

ANGLING ABROAD 



\section{I}

\section{AN ALBANIAN TROUT-STREAM}

THIS is an old memory, almost as old as 1 that of my first trout, a memory of the Mediterranean Flagship, sailing-sometimes literally sailing without the aid of steam-in summer seas "up the Straits." We anchored in Avlona Bay, that wonderful land-locked harbour in Albania. The chart showed a little stream running into the sea near the entrance of the bay, and the word was passed to the uninitiated that that stream held trout, and good ones. The weather was blazingly hot; day after day a hot sun had shone in a hard blue sky, and there was no prospect of a cloud therein for several months; we are so seldom troubled in that way in the British Isles that it is difficult to imagine the longing for a cloudy sky, and for the smell of a shower striking on parched earth. In those days the ships of our Mediterranean Fleet were painted black, and although we had spread an awning-curtain, like 
a little crinoline, outside the ship at the level of the upper deck, and that kept off some of the direct heat of the sunshine, we got the full benefit of the rays reflected from the water, which struck the ship's side and intensified the heat within. Canvas "windsails," to catch what air there was and carry it between decks, had been of some use at sea, but in harbour they hung limp and useless. The Admiral's gun had gone off as usual at 5 a.m. The sound of holystones on the deck above and of water swishing through the scuppers had come soon afterwards, and I remember lying on a cool grass-mat thinking that I had a day off, and planning how best to spend it. (Such use of a grass-mat, by the way, is a great aid to sleep in hot weather, because when sheets and pillows get hotter and hotter during the night a grass-mat does not.) Reflections from the sunlight on the water were playing about on the under-surface of the awning curtain, as seen through my port. A hot day was beginning after a hot night.

So the morning passed-the seaman's morning -which begins at 4 and ends at 8 a.m., with the hoisting of the white ensign aft, all hands saluting, to the tune of our national anthem. Hanging my head out of my port, to see whether the air outside was any cooler than it was in 


\section{AN ALBANIAN TROUT-STREAM 179}

the cabin, I noticed a shoal of mullet playing about amongst the odds and ends of shiprefuse which remained floating alongside the ship in those tideless waters, and those mullet reminded me of a fly-rod lying behind the boot-shelf on the bulkhead near the ceiling; it was the rod with which I had caught my first trout, presented to me when I left England by the old uncle who had given me the opportunity which led to so many of the joys of life. There was also an old fly-hook, with leaves of flannel, much moth-eaten, and, in parchment pockets, a good supply of small flies tied on rather thick gut, as most troutflies were in those days; in a pocket of the cover were coloured silks wound on cards, wax, and a few feathers. Some hold that no true sportsman buys his flies, he ties them for himself. My uncle held that view, as he also did the tradition that the shooting man should always clean his own guns and load his own cartridges; but those were more leisurely days, before we began to live working always up to the collar. I am afraid that I was never a true sportsman in the sense of preparing my own tackle, knotting up my casts, or tying my flies, but it is never too late to mend, and perhaps, some day, the struggle for existence 
will be less strenuous, and there will be time to amend my ways. It must add much to the pleasure of landing a trout to feel that the fly he has taken is of one's own making. I once knew an old farmer in Staffordshire, a keen fly-fisher all his life, who made all his tackle himself, even his rod, and a wonderful rod it was, fashioned of hard snake-wood, with a greenheart top. I cannot imagine anyone attempting in these days to compete with the professional builders of rods, and certainly no one would aspire to make one of the presentday reels, which add so much to a fisherman's joys. An angler abroad is sorely handicapped if he cannot tie his own flies, and our stock of them at Avlona soon ran out, and could not be replaced. As regards patterns, the local trout were very unsophisticated; they did not seem to mind the size of the fly much, or even the thickness of the gut, so long as you cast a light line; their only particular fancy seemed to be for a touch of red in the body of the fly.

We had a fairly good day with them, in spite of the terrific heat. I managed, by cajolement, to borrow the wardroom skiff-it would have been hopeless for a youngster to approach the commander of a battleship with any proposal to use a service boat, and so withdraw men from 


\section{AN ALBANIAN TROUT-STREAM 181}

the strenuous painting and polishing of bright work which made the men-of-war of those days so spotless and wonderful. I also managed to get a day's leave for one of the senior midshipmen, who was a keen fisher, and having rationed the skiff and added a barricoe of fresh (condensed) water, because the drinking of "shore water" in those regions is the surest road to the naval hospital, if not to the cemetery, we started off upon our three-mile pull, the skiff's awning spread over us to keep off the sun. We left at about 9.30, as "Divisions" on board ship, a parade and muster followed by prayers, is not a function that can be avoided, and we arrived at a bit of sandy beach by the mouth of the stream, full of hope. The stream itself looked perfect for trout, and even if there were none there it looked as if there ought to be. There was a mill, with a mill-pool above it, about three-quarters of a mile from the sea, but it was no day for fishing with a wet fly in still pools; the fast parts in the stream below gave a better chance, especially where the current ran into stiller water at the top of a pool, or where it began to run off at the bottom. The trout that we took averaged small. On such a day no mature and self-respecting fish, however inexperienced, 
would be deceived by artificial flies, heavily winged as ours were, attached to too-stout gut. The water was alive with small trout, and it is not far wrong to assume that the amount of food in any given trout-stream will support a certain weight of fish, so the numbers vary with the weight, the fewer the bigger. We caught plenty of little ones, and the memory of that long day by running water and rank, green vegetation helped us afterwards through many days of baking heat when the sun smote through the awning to the decks, and made the pitch-caulking bubble between the white planks.

In the evening, when the best fishing began, we no longer had the river to ourselves. In the afternoon the usual officers' boats had put off, bristling with rod-cases, from our own and from other ships. Before long there were waving rods, from little ones of eight or nine feet to salmon rods of eighteen feet, within fifty yards of each other all the way up both banks of the little river. Some of those wielding them had fished before, some had not. All were keen, and those who had the good luck to flog a bit of water first were generally rewarded. I noticed one shipmate, a lieutenant, at a moment when a four-ounce trout, attached to salmon gut, 


\section{AN ALBANIAN TROUT-STREAM 183}

was hurtling through the air behind him impelled by a heavy "strike" with a sixteen-foot salmon rod.

We made a regular day of it, and finished up with another form of fishing. As we were rowing homewards we saw a cutter and a gig putting off from our ship and making for the nearest point on the sandy beach, and we spotted a seine-net in the smaller boat. These seining parties from men-of-war are not to be missed. Wise commanders encourage them, as they afford a welcome change of scene for men constantly cooped up together in close quarters during a long cruise. Discipline is relaxed for the time, and the men wear any sort of " rig" they like, as they do when coaling, that strenuously dirty competitive effort now passing into oblivion with the introduction of oil-fuel. We decided to join that party, and landed near them. Piles of dry wood were soon collected, fires were lighted, the net was shot two or three times to the accompaniment of much divided authority, and of incessant advice in the tongue of the West Country, whenever the shore-line was passed from the gig to the keen spirits who waded in, shoulder-deep, to fetch it. All hands hauled with a will on the lines, and plenty of sea-fish were soon gleaming white in 
the moonlight on the sandy beach; many escaped in the scramble and confusion of the picnickers; we were mostly amateurs at the job. Clothes were then spread to dry by the camp fires where volunteer cooks had been making hot cocoa; - beer from the wardroom store went round, and we finished the evening with a sing-song. A hard-bitten old ordinary seaman, with no ambition, and a tendency to insobriety on occasions which would have sorely interfered with his career, if he had aspired to one, took virtual command of the party as the best singer. We packed up at last, pulled off to the ship, all hands taking a turn at the oars, and, when the falls had been hooked on, all " ranks and ratings" manned them to hoist the boats. So ended a lovely holiday by an Albanian trout-stream. We had another troutfishing or rather trout-hunting, experience there. The Admiral gave a party for all fly-fishers in his yacht, the Helicon, to which about fifty of us were invited. We landed at Avlona town to explore another, much bigger, river shown on the chart. The nearest bend of it was about six or seven miles inland along a glaring white, dusty road. Some few hired horses, some walked, myself among them. The river looked perfect, excepting in colour, which was slightly tinged 


\section{AN ALBANIAN TROUT-STREAM 185}

with blue! We put up our rods, selected flies with care, extended at about fifty yards interval between rods, and flogged the water for an hour in the hottest of hot suns. Then some one tasted the water-it was nearly as salt as the Dead Sea. We packed up, and tramped sadly homeward along the dusty road. That was my last experience of trout-fishing in Albania. 


\section{II}

\section{A NATAL TROUT}

THERE is a delightfully soft sound about

1 the word Mooi, when you hear it from the lips of a South African. It is rendered better by "lovely" than " beautiful," and lovely it is to arrive by a stream of running water, with infinite possibilities of trout therein, after a long sojourn on the high veld in a dry season, when all vegetation has been burned up by a hot sun by day or nipped by frost at night, and the nerves of the brain-workers are as strained and responsive as banjo strings. For some folk the drawback to visiting the Mooi River is that in the best trout-stocked parts there is no accommodation to be found on its banks. You must camp. Camping means transport, and in the days of which I write transport is difficult to obtain; but we are in a position to surmount that difficulty. A twentymile drive in a Cape cart, behind four mules, brings us from the nearest railway station to 
a perfect camping spot on short grass, near some small trees. There we can hear the subdued roar of a miniature cataract, caused by a sudden drop of about thirty or forty feet in the rocky channel of the river. Above the fall there is broad, open land covered with short grass; the stream is bordered with clumps of arum lilies and other rank marsh plants, but there is nothing to interfere with overhead casting. The river has cut for itself a fairly deep channel, constantly meandering in its course and providing about three miles of fishing for every mile of direct advance, in appearance rather like the River Axe as seen from the London and South-Western main line to Exeter. At each turn one bank is steep-to, forming a miniature cliff, the other bank shelving.

If want of accommodation was a drawback beforehand, because of all the trouble of collecting and transporting camp equipment and stores, it is a great advantage when all the preliminaries are over. We wake up early in glorious fresh air after a really restful sleep, with the pleasant feeling that there is a long fishing day ahead of us, exploring new water in complete solitude. The scent of a wood fire and the sound of frizzling bacon steal into 


\section{MOSTLY ABOUT TROUT}

the tents, and we hasten our ablutions and preparations. After breakfast we start off in different directions, full of hope and expectancy, with the waterfall as the boundary between our beats. These extend above and below it far beyond the range of the most adventurous. The upper beat is mine. We only muster one landing-net in our combined equipment, and it does not fall to my share to-day. My plan of campaign is to try the dry-fly in suitable spots, if trout or rises are to be seen; if not, to search the waters with wet flies.

Plop! . . . I am walking along the bank, where I cannot see over the edge on account of the rank vegetation, and I don't seem to recognize the note of that particular kind of "plop." I walk on a few yards. Plop! again. Then a few more yards, and constantly these plops, coming sometimes singly, sometimes in twos and threes. The mystery is soon solved. Frogs, big and little, but mostly little, are taking headers into the water as soon as they hear or feel my footsteps approaching. Not long ago I was shown, in a hotel in Durban, a six and a quarter pound brown trout in prime condition, caught (I could not find with what he had been beguiled) near this part of the river. I wondered at the time what diet had brought him up to that 
weight, and now I think that I know. The Mooi River was stocked with trout some years ago in the interests of fly-fishers, and we stick to the rule of "fly only" in these parts, though the minnow is also allowed in some of the beats below. I begin in hope, watching for rises. During that first long day of flogging the water in the sweltering heat I ponder deeply at times over a fly-book stocked with sea-trout sizes, wondering which of them looks most like a small frog. Not a trout shows up anywhere, and the water is not clear enough to see what is going on more than six inches or so below the surface. I can only imagine the fate of the froglets making those perpetual little plops by their headers off the bank.

It gets hotter and hotter and mysteriously still. There is not a breath of air. At last I give in, tired out, lie down with my back against a bank facing the Drakensberg range of mountains, which shows up clearly in the distance, and soon fall fast asleep. I am woken up by a blinding flash and a clash of thunder. A complete change has come over the scene. A thunderstorm has left the mountains and is sweeping slowly down the course of the river, but only the edge of it has reached me as yet; looking down-stream, I can see the country 


\section{MOSTLY ABOUT TROUT}

still bathed in sunlight. Up-stream, heavy clouds shut off the view of the river, with lightning flashes playing perpetually over their indigo background. The disappearance of the trout all day is accounted for, and it is obviously worth my while to try again under the new conditions; but by the time I have picked up my rod and begun to cast, the lightning is on all sides of me, and I feel like a prominent, timid and very unnecessary excrescence upon the landscape. My rod seems to be inviting the vengeance of the elements if I keep it pointed upwards like a lightning-conductor, so I compromise between timidity and keenness by casting underhand across the head of the pool and let the stream work the flies, a "woodcock and yellow" for the tail-fly and a "Zulu," as a tribute to local associations, as a dropper. In a few minutes I am rewarded. Something unseen takes hold, deep under water; the rod bends right down to the butt when I try a steady strain, so I know that something to be worth the landing. There is no more thought of the lightning or of the crashing thunder accompaniment to the twenty minutes' battle. The trout plays like a sulky salmon (its weight turns out to be three and a half pounds when landed). My gut is old, brought out from 


\section{A NATAL TROUT}

England years before, and I dare not take liberties, but luckily the water is clear of all obstructions and the bank on my side forms a gently shelving little beach. Slowly and surely does he at last respond to pressure, until his head is actually aground. I get behind him in the shallow water, holding up the rod and keeping a gentle strain landwards, get my foot slowly under him, and a heave sends him well up the pebble slope. Down goes the rod, and I am on my knees, grasping by the gills my first Natal trout, more than double the weight of any of his successors that found their way from the Mooi River into my basket-one of those sudden turns of fortune that come to us sometimes at the end of an exhausting and disappointing day's fishing.

And so homewards, past the arum lilies ("pig lilies," their local name!) and the froglets still plopping to their doom. Back through the slanting sunrays, the thunderstorm rolling down the valley before me, towards my companion on his homeward way to the camp. A glorious sunset, gilding the mountains in the west and glowing rose-coloured over the low clouds in the eastern sky, and suddenly the night is upon us. A welcome and refreshing tea, a tub in a canvas bath, and a long, peace- 
ful evening, with tired limbs relaxed, talking over things great and small with my companion in sport, a very great man, then and always thought of as "my Chief," under the glittering stars of a South African night. 


\section{III \\ SEA-FISHING IN SIMON'S BAY}

CIMON'S TOWN is a queer little place, $\checkmark$ dominated on one side by a mountain topped with gorgeous heaths and wild flowers and on the other side by immense docks, usually empty. Between them is old Admiralty House, with its lovely garden, and Simon's Town itself, straggling along the road between the mountain and the shore, and peopled chiefly by a coloured parasitic population depending directly, as we all do indirectly, upon the British Navy for means of existence. For the sea-fisherman the bay has infinite possibilities, provided that he takes expert advice about time, tide and locality. You can fish with rod or hand-line from the huge breakwater; there your bait often seems to be anchored to the bottom. Something tells you that there is life in the thing at the other end of your line, and you long for a capstan or winch to put on an extra strain. It is a gigantic cuttlefish. Using your whole 


\section{MOSTLY ABOUT TROUT}

strength, you may detach his hold of the bottom, only to see him let go the bait as it breaks the surface. There is but little sport to be had off the breakwater, but there are lessons to be learned. You may catch an "elf," a sporting little fish, excellent eating, but take care that the eating is all done on your side. Once I landed a little beauty, of about half a pound, and treated him as I would a small trout: I put my thumb in his mouth to force it open and extract the hook. Instead of opening wider, the little jaws closed like a vice, overlapping, and the tip of my thumb remained inside them, detached from the thumb itself, which was left outside, bleeding profusely. A painful proceeding, avoided by experienced fishers in those waters.

For the best sport with the sea fishes of Simon's Bay you must use a boat, and for work beyond the shelter of the breakwater the bigger the boat the better. There is grand fishing with a hand-line for Cape salmon near the Lighthouse, well out in the bay, but it is sometimes a trying experience. During the summer weather it always seems to be blowing hard, and I never yet met a fisher keen enough to count sea-sickness of no account compared with his sport. The skipper of a certain Brixham 


\section{SEA-FISHING IN SIMON'S BAY 195}

trawler has a tale to tell of a certain friend in whose honour he provided a specially solid "plum duff," after riding for hours on a long glassy swell, and was promptly implored to return at once to harbour. As that friend was the writer of these notes; it may be assumed that a calm day was selected to try for Cape salmon by the Lighthouse. We dropped anchor in deep water near a ridge of rocks, fixing our position by cross-bearings known only to the initiated, and in about an hour and a quarter caught a heavier weight of fish than I have ever seen "landed" in the time, about $400 \mathrm{lb}$. The method sounds simple enough. We used big hooks, with huge chunks of mackerel as bait and no leads to weight our lines, two of which were held by expert Malay fishermen, who at first caught at least three fish to our one. We soon found out the reason. The weight of the great length of line we had to use, and the pull of the tide, made it very difficult to feel when a fish had taken the bait; you had to strike at what felt like only a touch. Then, again, knowing that we were after twentypounders, we treated them with respect -and "played" them, thereby losing much skin from our fingers, wasting much time, and sometimes losing our fish. The long, nervous fingers of 


\section{MOSTLY ABOUT TROUT}

the Malays helped them to feel the least little tug, and instantly they hauled up, hand over hand, got their fish to the surface and into the boat, without leaving them time to diagnose the situation. Well, if catching fish is the only object of the fisherman, no matter how they are caught, I think that about twenty fish weighing $400 \mathrm{lb}$. in an hour and a quarter should satisfy anyone.

But, from the sportsman's point of view, Simon's Bay has better to offer when the "snook" is about. Let me introduce him. On your way through the street of the little town you will notice him first with your nose. You will then see him hanging up, split open and smoked, by the sides of many doorways of houses and shops; and when properly cured and cooked, "Cape snook" is by no means to be despised. You may have a talk with some expert who warns you to beware of being bitten . when you are extricating your hook from the mouth of a snook. You will see a Malay fisherman, directly he gets one into the boat, clasp it firmly under his left arm to hold its head steady; then a tremendous blow on the top of the fish's head with a boat's stretcher, belayingpin, or what-not, to stop the snapping of its jaws, and then the hook can be safely removed. 


\section{SEA-FISHING IN SIMON'S BAY 197}

While waiting for our boat, we were told a gruesome story of an old fisherman who had neglected these precautions, was bitten in the hand by the poisonous teeth of a snook, and "before they could get him home to Kalk Bay he was a corp!"

So much for snook in general. Now for the snook that gave me one of my most exciting experiences in forty years of fishing, in sea water and in fresh. This time I had only one companion, an Oxford undergraduate who had come out on a short visit to South Africa, and our boat was a very small one, a little twelvefoot skiff belonging to the flagship of the Cape squadron. The snook were good enough at that time to come close inshore, so we could keep well under the shelter of the breakwater, and there was no need to venture out into the nasty lop in the open bay. Before leaving England I had provided myself with a sea rod with a whole-cane butt and a greenheart top, quite a short rod, as a long one would be unwieldy to handle in a boat. It was impossible to get ashore to land a fish, as one does with a salmon, and a snook plays like a salmon, only very much more so. He turns mad directly he is hooked and makes wild runs incessantly, every bit of his great length wriggling and 


\section{MOSTLY ABOUT TROUT}

tugging furiously to get free. With so short a rod it is not easy to master such a fish, so I had also provided myself with an immense Nottingham reel, holding about two hundred yards of line. The first snook we can deal with briefly. He tore line off the reel as soon as he was hooked, but all went well, and we got him alongside and gaffed him in about five minutes. He weighed between nine and ten pounds. Now for the great experience.

The second snook I hooked made a mighty run, the reel screeching on hot bearings as he went. Before his run was at an end the reel came off the rod, banged down on one of the thwarts of the boat and bounded overboard, sinking, spinning as it went, to the bottom of the sea. There I was, helpless, holding up my rod, with a mad fish at one end of the line and a big reel at the other end, both making off at speed. They say that a drowning man remembers all the events of his life during his last few minutes. I have always wondered how they know that he does, but in my own great emergency I wished that I could remember whether I had fixed the end of my line firmly to the drum in the middle of the big reel. Anyhow, it was too late to do so now, and the only chance was to retrieve the reel from the bottom, mean- 


\section{SEA-FISHING IN SIMON'S BAY 199}

while "hand-lining" the fish as best I could. It was impossible, of course, to control his mad rushes in any way. My "crew" rose to the occasion splendidly, got hold of the line in the direction of the reel, and hauled in, hand over hand, while I kept the recovered line clear of everything in the boat, so that the fish could run it out if he wanted to, which he did, frequently. By hauling up full speed hand over hand, my companion recovered the reel, still spinning, with plenty of line on the drum,? after several ineffective attempts, as the reel sank spinning again whenever he slacked the line for a second to grab it. Landing that reel was as exciting a sport as landing any fish, but at last it was in the boat. The next step was to wind up on the reel the eighty yards or so of slack line in the boat, taking care to get no kinks in it, when the fish was taking out line in one direction and the reel in the other.

At last the line was on the reel and the reel on the butt of the rod; the fish chose that moment to make a rush across under the bows of the boat, followed by another rush back again across the stern, a manœuvre which a few minutes before would have defeated us by making a bight of line round the part with which we were hauling the reel up from the 
bottom. The rest of the struggle followed the normal course, and the snook was in the boat about twenty minutes-seeming like twenty hours-from the time when he was hooked. He weighed twelve pounds.

So ended the most exciting experience I ever had when sea fishing, either in Simon's Bay or elsewhere. 


\section{PART IV}

HOLIDAYS AND A WAR MEMORY 



\section{I}

\section{AUGUST IN NORTH DEVON}

R ED earth, red cows, and here and there R on the hill-sides a ploughed field glowing red in the afternoon sunshine as we look out of the train window near the top of the Taw Valley, Exeter behind us, well on our way to the North Devon coast! Signs of heavy rain everywhere: red puddles on the roads, and a little brook with reddened waters crossing and recrossing the railway line, swelling gradually into a trout-stream flowing through woodlands and fields, then into a salmon river, and finally into a wide estuary. Past the shipyards and church tower of Barnstaple. On the right the little narrow-gauge line wandering away to Exmoor and Lynton; on the left the junction of Taw $\$ and Torridge, just inside the harbour bar that moaned to the wives of Charles Kingsley's "three fishers" in the great gale; Bideford, Appledore, Instow, Westward Ho!, and beyond them the bold 
coast-line away past Clovelly to Hartland Point and Lighthouse. In the near foreground a wide expanse of wet sand, opal-tinted like the neck feathers of a dove, and numberless sea birds following up the wavelets of the receding tide or wading in the shallow pools that it has left behind. Excited children crowding to the train windows to greet with delight each well remembered object in the view. Those are the first impressions of an August holiday in North Devon. It is well to make the best of them.

At each station the train discharges its load of families of all sizes, piles of luggage, perambulators, little cots, and bundles of spades, buckets and butterfly-nets. Strings of vehicles, from the donkey-drawn governess-cart to the opulent motor, wait to distribute them to their destinations. The coast road skirts round Saunton Hill, now a blaze of crimson heath and wild flowers; a glorious view of the sands, of the bluff granite headlands across the bay, of Lundy Island to seaward, and soon we come to our goal, a cluster of small farms and a little village of whitewashed cottages straggling up a narrow valley with a miniature trout-stream babbling over pebbles by the roadside. The little gardens are bright with fuchsias, nasturtiums and pinks, and the banks of the tiny stream with yellow 


\section{AUGUST IN NORTH DEVON 205}

musk. Barring the view to seaward is a belt of sand-dunes. Beyond them a beach of perfect yellow sand, smooth and hard; here and there a ridge of rocks with fascinating little pools, and beyond the sands a thundering line of surf, remnant of a recent gale. Prospects of a whole month on those sands, shoeless and stockingless, amongst the little companies of rejoicing youngsters-if only this evening's sunshine lasts!

It does not. Day after day, night after night, the wind blows and the rain beats against rattling windows. Mackintoshes, windowwedges and bottles of cough-mixture, produced from the depths of trunks by wise Nannies with foresight, are the most useful contents of the luggage. Everything out-o'-doors looks grey, except the red puddles in the lane. There is nothing for it but to make the best of indoors, with an occasional sally in mackintoshes along muddy lanes between hedges of dripping honeysuckle to buy pottery in a neighbouring village or Devonshire cream from a farmer's wife, a friend of old. Then homewards through the mud, the glow of dry clothing, and a jammy and creamy tea. A whole fortnight of storms and gales, with interludes of driving rain and wet sea mists. Two precious weeks out of a 
holiday of four, looked forward to for months. If this goes on there is nothing for it but to tear up this account and pocket the fountain pen. It is permitted to share our joys with others. We must keep our tragedies under bushels, or their present-day equivalents. ...

What ages it seems since our whole world was bounded by rattling windows, with rainsqualls driving against the streaming panes! It could not have been only yesterday morning. In the evening Nature's great magician got to work. The sun burst through the clouds, the wind drove them in rolling billows up the valleys, the headlands stood out, and Lundy Island suddenly appeared again on the horizon, dimly outlined in soft blues and greys. We had a sunset, unpaintable, but describable in prose, as only Ruskin could have described it.

To-day has come the dawn of summer. Warm zephyrs waft the scent of honeysuckle, diluted with ozone from the sea beach, into widely opened windows. The landscape is a blaze of colour, grass of the emerald-green of the West of England and of Ireland; patches of ripening corn show yellow in the little fieldlets between the high hedges on the hillside, and Saunton Hill is gay again with wild flowers, purple, yellow, orange, red and blue. 


\section{AUGUST IN NORTH DEVON 207}

Processions of bare legs, from the lean and long to the short, fat and chubby, wend their way towards the joys of the beach, the sandcastles, rock-pools, shrimping, paddling, surfbathing, sand-cricket, golf, sandhill toboganning and other delights. The finest sight in the world, healthy young England at play by the sea, with the gorgeous background of "glorious Devon." This is no time for indoors. Again I put away the pen, and this time for a real outdoor day. 


\section{II}

\section{A BUTTERFLY-HUNT BY THE SEA}

RY the sea, as Nature left it-by the sea, washing into sandy bays or thundering into little natural harbours between cruel granite rock ridges at the foot of cliffs crowned with downlands and clover-fields, beloved of brilliant blue butterflies and their more soberly clad spouses. Patches of green turf, studded with sea-pinks and orange-yellow lady's-slipper, where soil has lodged on shelves and crevices in the cliffs.

It is good to lie in the warm sun by the shore. It is good to wade into the sea, past the buffeting of the breakers, and to swim lazily in the calm water beyond, heaving with the Atlantic swell in the heat-haze brooding over the waters. For full enjoyment of the cool sea water it is also good to take some exercise first and to get really hot; butterfly-hunting gives an excuse for a climb up a little airless lane, shaded by high flowery banks, to the fresher air of the fields 


\section{A BUTTERFLY HUNT}

and downlands above. The banks are topped with brambles, heavy with ripening fruit and entwined with late honeysuckle, which is just coming into bloom. ... What is it that teaches butterflies to study effective backgrounds? Why does the Red Admiral spread his black and scarlet beauty on great clumps of yellow fleabane, which blaze in the hot sunshine on the bank bordering the sunny side of the lane? Why does the Peacock, umber-red and smokygrey, with great black spots dusted with skyblue, poise itself on the right shade of mauve background, provided by the spreading heads of hemp agrimony?

Absorbed in such thoughts, we wander upwards by the narrow lane, picking our way at times from stone to stone, where a spring of clear water has burst its way through the bank, choosing the little lane as the easiest route by which to go tinkling down the hill-side to the sea. Then the lane narrows perceptibly, the banks growing higher than ever, till we pass through a mysterious shady tunnel where branches of sloe and oak scrub meet overhead and the sunshine penetrates only in a shimmer of greenish light. Here we find what we are looking for, a pair of Speckled Wood (or Wood Argus) butterflies, with their dancing flight, 
flickering velvety black and lemon-yellow in the dim light. A sweep of the net secures them. A few minutes spent here for contemplation before breasting the steep slope above, a pipe in the cool shade, and then into the hot sunshine again. An old wooden gate, grey with age and stained with orange lichen, soon breaks the line of the banks. It opens on to a wide expanse of luscious green clover, the distant blue sea beyond it far below. The air is heavy with honey-sweet scent from myriads of blossoms, pink and white. The humming of innumerable black and orange bumble-bees comes through the gateway with the scent. Many little blue butterflies are flitting from cloverhead to clover-head, and we wait for the chance of the one we want, the smallest of all British butterflies, the wee Bedford Blue, really more brown than blue, but with a bluish gloss to justify its name. Not easy to see, unless you have good sight, and late in the year to find them, unless we have the luck to happen upon a second brood.

As we are getting over the gate, what we thought was a common Meadow Brown settles in the lane and gives us a chance of better inspection. It proves to be a Grayling, not at all common in these parts, and we go back to 


\section{A BUTTERFLY HUNT}

secure it. Then return to the field, where we skirt along the border and note the tracks of rabbit-runs through the dew-wet clover to and from the burrows in the bank. Plenty of Common Blues are to be seen, and we make a few careful incursions, treading delicately, into the deep clover to inspect them as they settle; always worth while, because you never can be quite sure of the species of a blue butterfly when on the wing. By the time that we reach the top of the field we have the luck to get two of the tiny brownish Bedfords.

Then, in a hot corner of the field, facing south and sheltered by high hedges from the cool breeze, we wait awhile, and we are rewarded by seeing three Peacocks, five Red Admirals and a small Tortoiseshell passing in about ten minutes, perfect specimens, freshly hatched and gorgeous in colouring. Here we have a spell of bad luck or want of skill. They are all very wary and strong on the wing; only one permits approach to within reach of a stroke of the net, and that one is so surrounded by thorny brambles that the net catches, and it flashes over the fence to join those that have passed before it and gone on their way rejoicing. We return to the gate and go round by the lane to investigate the unknown ground beyond the 


\section{MOSTLY ABOUT TROUT}

hedge; we find it to be a tiny footpath, sheltered by high fences, and a regular sun-trap, blazing with wild flowers, a butterflies' paradise. As usual, the whites are most conspicuous. The majority of these prove to be the "greenveined" sort, only a few the common or "garden"; but though the whites are most conspicuous, browns are far more numerous, chiefly the Meadow Brown and the Large Heath, both, for some unknown reason, more brilliant on the under than the upper side, perhaps because more often than not they close their wings when settled on a bright background. We leave these varieties at large, but secure two good specimens of the Wall Brown, with its orange and sepia markings; we want them for the collection. At the end of the little path we find the haunt of the Red Admirals and Peacocks, and we have better luck with them this time, at the expense of a rent in the net, again caught in a bramble.

It gets hotter and hotter, so hot that the call of the cool sea is irresistible, and we turn on our way homeward across country, noting the wild flowers in the banks and hedgerows that we pass.

And so to the beach and a glorious swim, followed by the drying of ourselves in the hot sand of a wee valley screened by the dunes. 


\section{A BUTTERFLY HUNT}

A sleepy revel in the warmth of clothing which we spread in the sunshine to bake while we bathed, and then lazily homewards to set the butterflies and preserve, with them, the memories of a glorious summer's day. Every butterfly in the collection has some association with the surroundings of its capture. A box of them, like the mind of a wise old man, preserves a wealth of sunshine and summer scenes to tide over the cold, dark days of winter. 


\section{III}

\section{A SEASIDE IDYLL}

HIS is the seaside at its best. There is 1 no sea-wall. The beach is not pebbly. There is no esplanade, and there are no bathingmachines, no hotels and no " amusements." Real country extends down to the very beach itself. Behind us is the little straggling village of whitewashed thatched cottages, with fuchsias hanging over the road from their wee gardens, and one garden has two shady fig-trees with thick trunks that must have seen two or three centuries. The little clear brook babbling by the road turns a miniature mill, all overgrown with ferns. Every sort of rock-plant grows on the walls, which are topped with wallflowers and foxgloves. The shady lanes have high banks with hartstongue ferns, foxgloves again, willow-herb, speedwell, red and white campion, vetches, trefoil, scarlet pimpernel, mallows, convolvulus, scarlet poppies, marguerites, and other wild-flowers galore. One of these lanes takes us down to the sea-shore. At every gateway 


\section{A SEASIDE IDYLL}

we pass we have a glimpse of a sparkling silver sea, and on the far horizon an island shows up, with bluff cliffs dimly outlined in the heat-haze. We turn at the end of the lane down a pebbled footpath taking us to the beach, which lies between two bold headlands forming a little bay. At each end of the beach are rock-ridges, with baylets of hard sand between them, and amongst the rocks mysterious pools of clear water, fringed with seaweeds and coralline of all colours; the prevailing tones are vivid green and soft greys and purples. Deep orange seaanemones wave their tentacles from the sides, limpets and sea-snails of all shades of orange and opal cling to the overhanging rocks. There are rumours of iridescent prawns, and even of conger-eels and lobsters, lurking in deep, shady crevices where the eye cannot reach. Between the rock-ledges on the two sides of the bay lies about half a mile of fine hard sand, glistening wet in the sunshine. The beach is shut off from the fields by a ridge of sand-dunes, cleft where our little stream finds its way to the sea. Near where the rocks meet the sand-dunes at one end of the little bay there are great orange, red and yellow patches of the gorgeous lady'sslipper, and between them bits of short turf dotted with sea-pinks. The land side of the 
sand-dunes is carpeted with acres of dwarf wild roses, each miniature plant only two or three inches high, and the scent of the roses sweetens the gentle sea-breeze. The course of the stream through the low-lying fields is marked by long belts of yellow iris, till we lose sight of it where it runs through the village. The view shoreward is of rich land divided up into small fields of all shapes and sizes by high banks and hedges, and, above them all, patches of downland dotted with sheep cropping the short grass or nibbling the young shoots of the gorse. From the sides of the valley the distant note of a late cuckoo reaches us faintly, and on our way down the lane we heard a pigeon crooning in a wood on the hill-side. Other birds are silent, busy with the care of new broods in tree or hedgerow now in full leaf. From the beach come the sounds of gently breaking surf and foaming back-wash and the shouts of joy of happy children.

We soon come to a group of small paddlers, busy with spades and buckets, trying to dam up the course of a salt streamlet running through channels in the hard sand from one of the bigger rock-pools to the sea. They range in age downwards to a chubby, fat-legged youngster of two or three, shrieking with glee, sitting in a beachpool and defying a nurse, who stands stockinged 


\section{A SEASIDE IDYLL}

and shod on its edge. Other groups are dotted about amongst the rock-pools, along the beach and on the sandhills, taking their turn to roll down the soft warm sand-slopes to the shore. The whole air is filled with youthful energy and joy. As we get nearer to the first group, they see us, abandon their great drainage works, and run barefoot towards us across the wet sands-prancing with delight and the joys of childhood let loose on the sea-shore.

It is not the seaside of a dream, it is all real ; we have found the best sort of children of allour own. This is a real seaside holiday, with two more weeks of it to run, and the poor townsfolk on their reeking pavements in the blazing sunshine seem very far away. Let us find a little bit of shade under the rocks, inspect the collection of crabs, limpets and other sea beasts in the buckets, boil the tea-kettle and have a big tea, with lots of freshly made yellow butter, as much of it as we want, spread upon bread of to-day's baking; and, in the absence of a Cream Controller, Devonshire cream.

After tea, a reposeful pipe, as I lie in the soft warm sand, with my back against a rock, and watch a youthful fisherman with toy rod and line, barbless hook baited with gingerbread, qualifying for much future dẹlight. 


\section{IV}

\section{A WAR MEMORY}

PHOUGHTS of North Devon bring back

1 other memories, of a day when a long swell was coming in from seawards, a sure sign of some disturbance in the west. The Emerald Isle does not intervene between Devon and America. There is only the open Atlantic, where our common ancestors, the Elizabethan seamen of old, went Westward Ho! to fight for the true freedom of the seas against the Spaniard. Charles Kingsley, from our little picnic beach, used to gaze across that western sea. His monument stands nearby, at Bideford. It was from this very beach, or close to it, that he stepped into the Clovelly trawler's boat and held forth upon things seen and unseen to his artist friend "Claud Mellot." It may have been here, too, that he wrote, as I am writing now, "Westward Ho! we have prospered." Soon, on the day of my remembrance, white horses began to show on the long Atlantic 


\section{A WAR MEMORY}

swell, their creaming crests surging forward to form great breakers on the beach. They reminded me of surf-bathing witnessed in distant seas.

Surf-bathers use the waves as the shrewd folk at the head of affairs in Whitehall use public opinion. They carry their little planks out into the sea, keeping well within their depth, and watch their opportunity. Seeing a great wave come swelling in from the ocean, they jump upwards to its crest. They must do so at exactly the right moment, when the top of the swell begins to foam and fret before forming a seething and crashing breaker. If they jump too soon, they are not carried forward themselves, though they may possibly make the wave break sooner and help others, wiser than they, to ride upon its crest. If they jump too late, they are engulfed in the breaker itself, which rolls them over and over, buffeted by the clashing pebbles, in the hissing streams of the back-wash. If they jump at the right time, they enjoy the exhilarating experience of being swept forward to safety on shore, poised upon the summit of the surging surf, which they can use, but cannot create. So with the good folk in Whitehall, the scene of this war memory.

That famous thoroughfare appeals to philo- 
sophic fishermen therein employed. They think of the stream of human traffic that flows past their office windows. Downing Street on the one side and Whitehall Gardens on the other form quiet backwaters, still waters that run very deep. The old Abbey divides the stream at one end and gives a sense of stability, restoring belief in the endurance of great ideals in human affairs. The neighbouring House of the Mother of Parliaments reminds them of the Anglo-Saxon belief in freedom for individuals and for nations to develop the best that is in them in their own way. At the far end Nelson, from his eminence, looks down upon the scene, guarded by lions calmly contemplating the stream, which first converges through a narrow channel and then broadens out towards the wide expanse between the great Offices of State, where the Cenotaph "To Our Glorious Dead" now stands in austere simplicity. Many of those whose martyrdom it commemorates were still with us on the day of which I write, the Fourth of July, 1918.

Those were anxious times. Haig, eleven weeks before, had told his tired men that, with backs to the wall, believing in the justice of their cause, each one must fight on to the end. The strip of land between his army and the 


\section{A WAR MEMORY}

sea was very narrow then. King Albert and the Belgians were standing on the last little bit of Belgian soil that had been saved from the invader. Rich provinces of France were occupied and devastated, and from all sides came the cry for more men. The enemy's reserves seemed to us still to be inexhaustible; blow after blow had fallen, and each time we had been obliged to give ground. Further blows were expected. Paris was being bombarded from afar, and Amiens, that vital railwayjunction, at close range. Our own homeland had not been invaded, and a glance at the Nelson Column reminded us that we could carry on, even if the war on land were lost on the Western Front; but at what cost to our Allies ? And could they stand further torture? Manpower alone could turn the scale, in time, and all eyes were turned to the West, across the Atlantic. Every office in Whitehall could show its map of the Western Front, with a row of little flags marking the constant loss of ground since March. The flags had been moved constantly westward, and it seemed that the tide of invasion would never reach its high-water mark.

I was looking at one of those maps on that July morning. On the way up Whitehall I had passed many tired-looking faces. "We are 
all tired," Haig had. written to his army, nearly three months before, and part of the nation was showing signs of strain, worn out by nearly four years of sacrifice and disappointment. A new impetus was sorely needed, a new enthusiasm to help us to endure to the end. Some were getting almost callous, seeing no light ahead.

Suddenly, through the open window of my office came from a distance a sound like the roar of a tidal wave or of surf, mingled with the shrill cries of sea-birds. It mounted in a great crescendo. The pavements filled with people, all heads turned towards the direction of the sound which came surging into my room, mounting to a climax of uproar, until the mystery was solved. Hundreds of American soldiers, cheering, yelling and waving flags, were driving through Whitehall in big brakes, smothered with bunting-the Stars and Stripes. The counter-cheers of Londoners, of soldiers, of seamen and of airmen, belonging to all parts of the British Empire, resounded from the pavements and windows and re-echoed from the surrounding buildings. The Fourth of July. What a memory, and what an outcome! In the presence of the great worldmenace a wave of good will was uplifting, for the time being, the Allied peoples; it carried 


\section{A WAR MEMORY}

them forward to their goal, the statesmen balancing their little planks upon its crest. It may have spent itself for a time in a great breaker, and the clashing pebbles can be heard in the back-wash, but the tide of human progress is still flowing, and wave after wave will follow. Politicians do not make them, and cannot stop them; they rise from the people. The statesmen who can gauge the right moment to jump are swept forward on the wave-crest, and their names are passed down with honour to generations to come. Hatred can destroy, it cannot create. It can kill men, or discredit their motives; it cannot kill the principles or the ideals for which they suffer. Good will is creative, returning in progressive waves from generation to generation. Such, at least, were the thoughts of a fisherman during that day's work in Whitehall, on the Fourth of July, in the last year of the Great Crusade. With that memory of one day's work we can close these reminiscences of happy holidays by stream, river and sea-shore, in the strong belief that "Only on farms or deep in the forest or out on the river while you fish, can you think a thing out clearly. For there your life goes quietly, and you learn only what is worth while." 
Printed in Great Britain by ONWIN BROTHERS, LIMTTED WOKING AND LONDON 
$+$

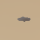

(1)

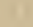

$=$

- 3

4

It

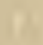

n<smiles>C1CCCCC1</smiles>

4 


\section{UNIVERSITY OF CALIFORNIA LIBRARY}

This book is DUE on the last date stamped helow

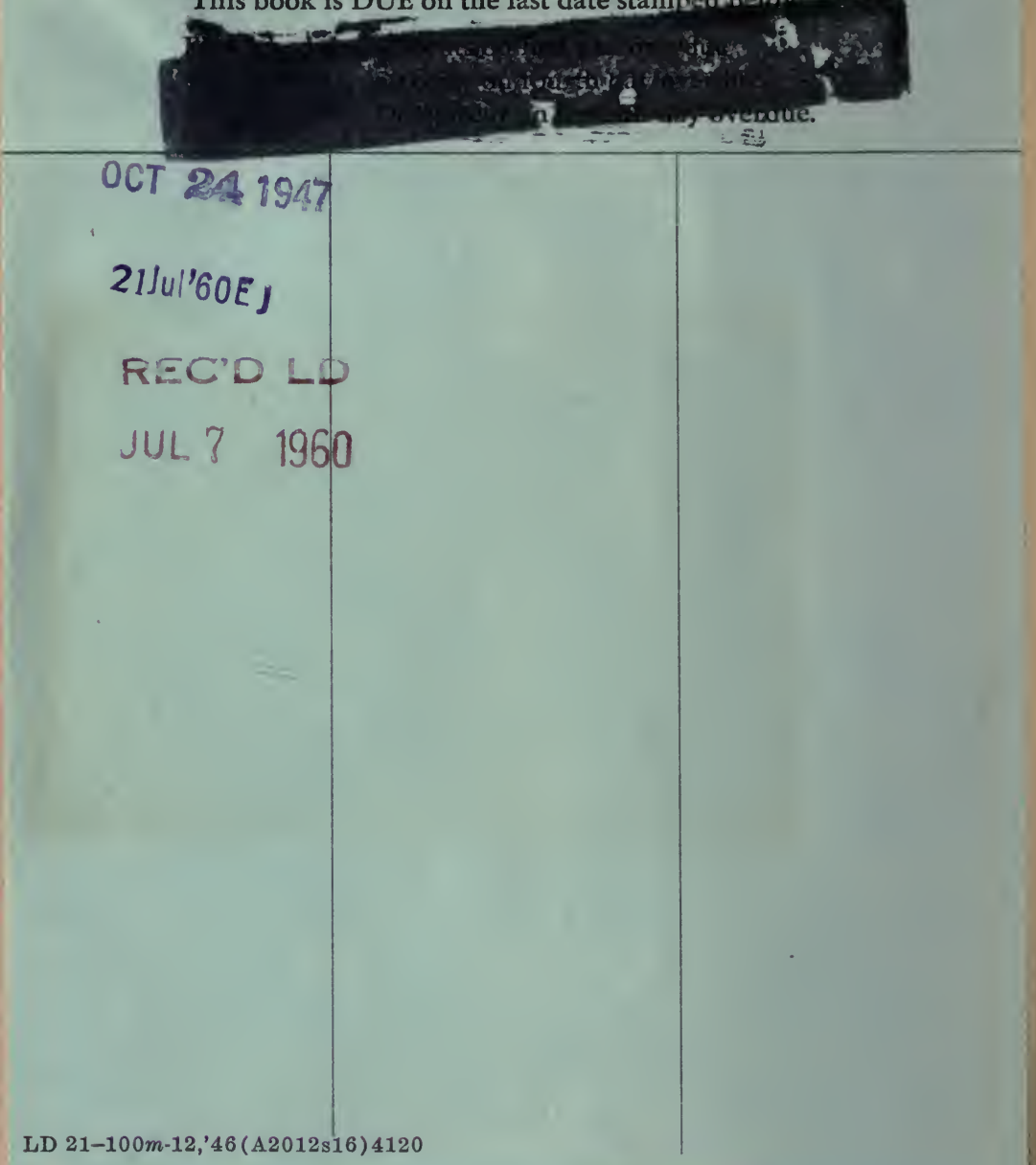




\section{2}

UNIVERSITY OF CALIFORNIA LIBRARY 


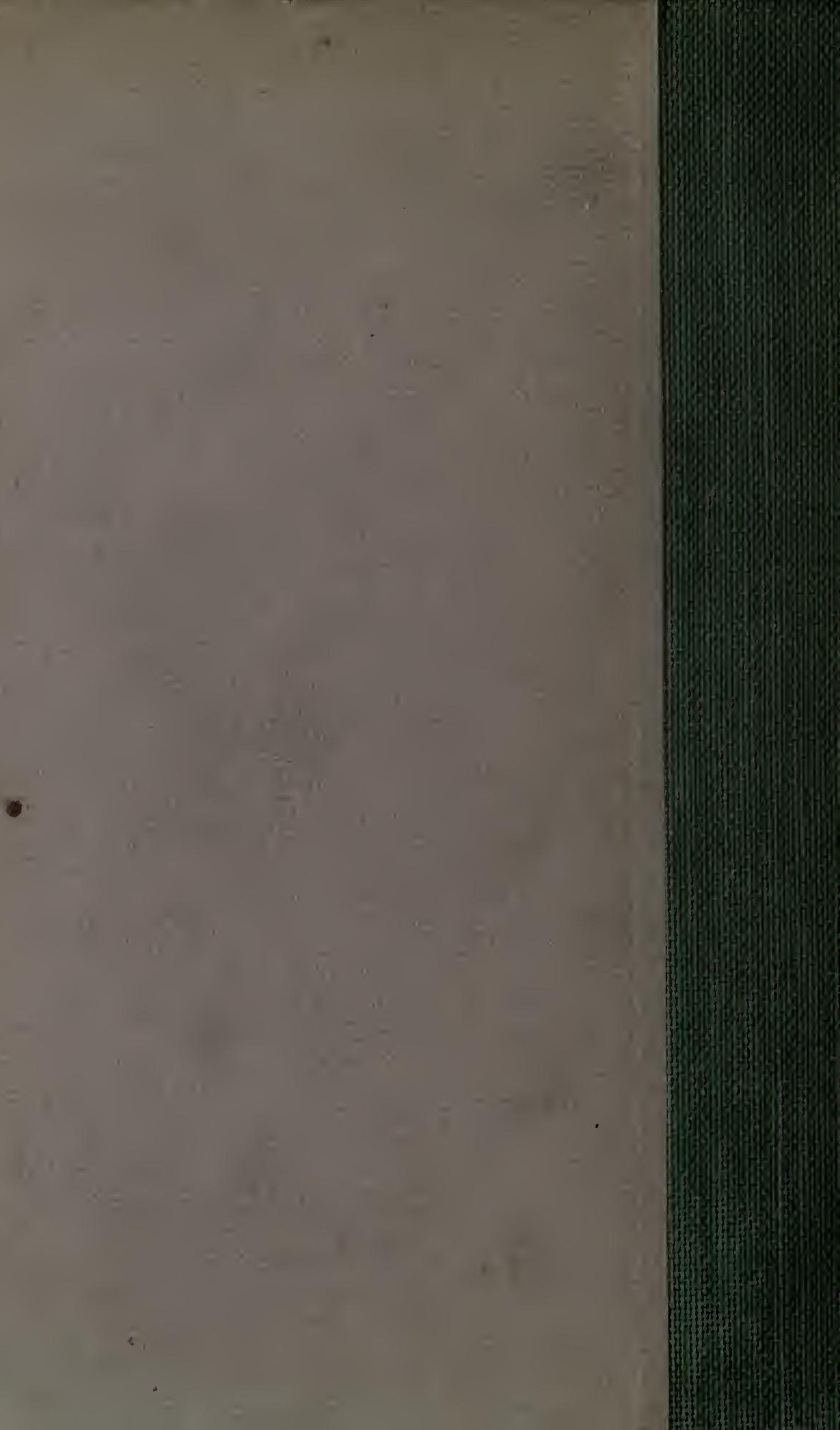

